\title{
콘텐츠 이용자 데이터 개발 기반연구
}

Research on Cultural Content Consumer Data Development 



\section{콘텐츠 이용자 데이터 개발 기반연구}

Research on Cultural Content Consumer Data Development

김소연·주익현 

연구책임

김소연 한국문화관광연구원 연구원

공동연구

주익현 광운대학교 산학협력단 연구교수 

콘텐츠 이용자 데이터 개발 기반연구

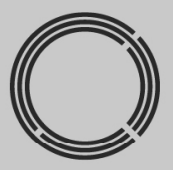

연구개요 



\section{1. 서론}

\section{가. 연구 배경 및 목적}

1) 연구 배경

- 콘텐츠 이용자들은 산업 생태계에서 위상이 크게 제고되어, 산업 내 변화나 산업 간 융합을 촉진하는데 큰 영향을 미치고 있음

- 콘텐츠 산업의 지속적인 성장과 효과적인 정책 수립을 위해서는 이제 사업체나 종 사자 층위에서 뿐만 아니라, 콘텐츠 이용자 데이터의 구축과 활용이 필요함

- 현재 공공 및 민간 영역에서 다양한 형태의 콘텐츠 이용자 데이터가 생산되고 있으 나, 이용자들의 변화 양상을 체계적으로 파악할 수 있는 데이터는 일부 대기업 중 심으로 접근성이 제한적인 편임

2) 연구 목적

- 본 연구에서는 향후 콘텐츠 이용자들의 변화 양상을 효과적으로 파악할 수 있는 데이터 개발의 필요성을 검토하고, 그 방안을 제시하고자 함

- 현재 콘텐츠 이용자를 대상으로 생산되고 있는 기존 주요 데이터 현황을 분석하여, 콘텐츠 이용자 조사 등 구체적인 데이터 구축 방안을 제시할 것을 목적으로 함

\section{나. 연구 범위 및 방법}

1) 연구 범위

- 본 연구는 공간적으로 우리나라에서 생산되는 콘텐츠 이용자 데이터를 주요 범위 로 설정하며, 시간적으로 가능한 한 최신 자료를 분석에 활용하도록 함

- 데이터 생산의 기초인 콘텐츠 및 이용자에 대한 정의와 범주, 측정 방식의 다양성 을 검토하고, 국내 주요 조사통계 자료의 경우 설계 구조와 내용을 심층 분석함

\section{2) 연구 방법}

- 본 연구의 주요 연구 방법은 문헌자료 분석과 전문가 자문임 


\section{2. 콘텐츠 이용자 데이터 현황}

\section{가. 콘텐츠 이용자의 정의와 범주}

- 콘텐츠, 콘텐츠 산업, 그리고 콘텐츠 이용에 대한 정의 방식은 국·내외 매우 다양 하며, 이에 따라 콘텐츠 이용자에 대한 정의를 명확하게 정립하는 것은 원천적으로 어려움

- 본 연구의 주 목적인 콘텐츠 이용자 데이터 개발 방안을 구체적으로 도출하기 위 해, 본 연구는 '콘텐츠 이용자'를 통계법상 콘텐츠산업 특수분류체계가 구분하는 콘텐츠를 이용하는 사람으로 설정함

- 콘텐츠 이용행위는 온라인 공간에서만 발생하는 것으로 국한되지 않고, 오프라인 공간의 행위로 확장되는 융·복합적인 성격을 가짐

\section{나. 콘텐츠 이용자 대상 데이터 생산 현황}

1) 정형 데이터

- 콘텐츠 이용자 층위에서 생산되고 있는 데이터들 가운데, 정형 데이터로 생산되는 가장 대표적인 형태가 조사통계 자료임

- 조사통계 자료는 공공, 민간 영역에서 가장 활발하고 다양하게 생산되나, 작성 목적에 따라 대표성 확보 여부에는 차이가 있음

- 국가승인 통계자료는 통계청 기준에 따라 표본설계시 비교적 엄격한 작성 심사 과정을 거치고, 표본추출시 필수적으로 확률표집 방법을 적용하기 때문에, 가장 대표성을 갖추었다는 강점이 있음

- 민간에서 생산되는 조사통계 자료들은 작성주체인 기업 또는 사업체가 비공개 로 진행하는 경우도 많아, 공개 자료 외에는 접근성이 제한적임

2) 비정형 데이터

- 콘텐츠 이용자 층위에서는 비정형 데이터도 활발하게 생산되며, 일반적으로 SNS 중심으로 자유롭게 생성되는 빅데이터가 가장 대표적임 
- 최근에는 데이터 수집 및 분석 방법과 관련된 기술이 발전하면서, 콘텐츠 이용양상 을 분석하기 위한 목적으로 트래킹 소프트웨어를 활용한 로그 데이터도 있음

- 콘텐츠 기업 내부적으로 활용하는 고객 데이터 흔적(Data trace)도 이에 해당함

3) 시사점

- 콘텐츠 이용자의 이용행태 관련 정보를 종합적으로 수집, 검토할 수 있는 데이터가 부족함

\section{3. 콘텐츠 이용자 대상 주요 데이터 분석 결과}

\section{가. 주요 조사통계 표본설계}

- 현재 공공영역에서 콘텐츠 이용자의 양상을 부분적으로나마 검토할 수 있는 국가 승인통계는 7 종, 지속적으로 생산되는 실태조사는 10종 정도로 파악됨

- 국가승인통계들은 대부분 횡단면 구조로 설계되어 있으며, 장기 추적조사하는 종 단면 자료는 보다 심층적인 정책 발굴이 가능하다는 장점이 있으나 조사 예산과 인력 등에 투입 자원이 많이 필요함

〈표〉 콘텐츠 이용자 대상 주요 국가승인통계

\begin{tabular}{|c|c|c|c|c|c|c|c|}
\hline 분야 & 조사명 & 대상 & 주기 & 연혁 & 표본규모 & 표본추출방법 & 자료배열 \\
\hline \multirow{2}{*}{ 문화 } & $\begin{array}{c}\text { 국민문화예술 } \\
\text { 활동조사 }\end{array}$ & 전국 만 15세 이상 & 1년 & $\begin{array}{l}\text { 1988년 } \\
\text { - 현재 }\end{array}$ & $\begin{array}{rl} & 10,000 \text { 가구 } \\
& (10,099 \text { 명 }) \\
※ & 99 \text { 명 추가조사 }\end{array}$ & $\begin{array}{l}\text { 다단계 층화 } \\
\text { 집락 확률표집 }\end{array}$ & 횡단 \\
\hline & $\begin{array}{c}\text { 국민여가활동 } \\
\text { 조사 }\end{array}$ & 전국 만 15세 이상 & 1년 & $\begin{array}{l}\text { 2006년 } \\
\text { - 현재 }\end{array}$ & $\begin{array}{rl} & 10,000 \text { 가구 } \\
& (10,088 \text { 명 }) \\
※ & 88 \text { 명 추가조사 }\end{array}$ & $\begin{array}{l}\text { 다단계 층화 } \\
\text { 집락 확률표집 }\end{array}$ & 횡단 \\
\hline 사회 & 생활시간조사 & 전국 만 10세 이상 & 5년 & $\begin{array}{l}\text { 1999년 } \\
\text { - 현재 }\end{array}$ & $\begin{array}{c}12,435 \text { 가구 } \\
\text { (26,091명) }\end{array}$ & $\begin{array}{c}\text { 다단계 층화 } \\
\text { 집락 확률표집 }\end{array}$ & 횡단 \\
\hline 미디어 & $\begin{array}{c}\text { 한국미디어 } \\
\text { 패널조사 }\end{array}$ & 전국 만 6세 이상 & 1년 & $\begin{array}{l}\text { 2010년 } \\
\text { - 현재 }\end{array}$ & $\begin{array}{l}4,260 \text { 가구 } \\
\text { (10,302명) }\end{array}$ & $\begin{array}{l}\text { 다단계 층화 } \\
\text { 집락 확률표집 }\end{array}$ & 종단 \\
\hline \multirow{2}{*}{$\begin{array}{l}\text { 과학 } \\
\text { 기술 }\end{array}$} & \begin{tabular}{|c} 
인터넷 \\
이용실태조사
\end{tabular} & 전국 만 3세 이상 & 1년 & $\begin{array}{l}\text { 1999년 } \\
\text { - 현재 }\end{array}$ & $\begin{array}{c}25,050 \text { 가구 } \\
\text { (60,000명) }\end{array}$ & $\begin{array}{c}\text { 다단계 층화 } \\
\text { 집락 확률표집 }\end{array}$ & 횡단 \\
\hline & $\begin{array}{c}\text { 방송매체 } \\
\text { 이용행태조사 }\end{array}$ & 전국 만 13세 이상 & 1년 & $\begin{array}{l}\text { 2000년 } \\
\text { - 현재 }\end{array}$ & $\begin{array}{c}4,042 \text { 가구 } \\
\text { (6,029명) }\end{array}$ & \begin{tabular}{|c} 
다단계 층화 \\
집락 확률표집
\end{tabular} & 횡단 \\
\hline
\end{tabular}




\begin{tabular}{|c|c|c|c|c|c|c|c|}
\hline 청소년 & $\begin{array}{l}\text { 청소년매체이 } \\
\text { 용및유해환경 } \\
\text { 실태조사 }\end{array}$ & 전국 초4 고3 학생 & 2년 & $\begin{array}{l}\text { 1999년 } \\
\text { - 현재 }\end{array}$ & $\begin{array}{c}\text { 633개 학교 } \\
\text { (14,536명 학생) }\end{array}$ & $\begin{array}{l}\text { 다단계 층화 } \\
\text { 집락 확률표집 }\end{array}$ & 횡단 \\
\hline
\end{tabular}

자료: 문화체육관광부(2020) 2020 국민문화예술활동조사;

문화체육관광부(2020) 2020 국민여가활동조사;

통계청(2019) 2019 생활시간조사;

정보통신정책연구원(2020) 2020 한국미디어패널조사;

과학기술정보통신부(2020) 2020 인터넷이용실태조사;

방송통신위원회(2020) 2020방송매체이용행태조사;

여성가족부(2020) 2020 청소년 매체이용 및 유해환경 실태조사 재정리

- 콘텐츠 세부산업별로 생산되는 주요 실태조사들은 표본 대표성에 있어서는 국가승 인통계 자료에 비해 부족한 측면이 있으나, 트렌드를 안정적으로 파악할 수 있는 데이터 자체가 안정적으로 생산되지 않고 있는 현실을 고려할 때 그 필요성과 가치 가 있음

〈표〉 콘텐츠 이용자 대상 주요 실태조사(비승인통계)

\begin{tabular}{|c|c|c|c|c|c|c|c|}
\hline 분야 & 조사명 & 대상 & 주기 & 연혁 & 표본규모 & 표본추출방법 & 자료배열 \\
\hline \multirow{7}{*}{$\begin{array}{l}\text { 콘텐츠 } \\
\text { 산업 }\end{array}$} & $\begin{array}{l}\text { 웹소설이용자 } \\
\text { 실태조사 }\end{array}$ & $\begin{array}{l}\text { 만 10세 이상 } \\
\text { 59세 이하 }\end{array}$ & - & 2020년 & $\begin{array}{c}\text { 이용자 2,008명 } \\
\text { 미이용자 1,330명 }\end{array}$ & $\begin{array}{c}\text { 성별·연령별- } \\
\text { 지역별 } \\
\text { 할당표집 }\end{array}$ & 횡단 \\
\hline & $\begin{array}{l}\text { 만화이용자 } \\
\text { 실태조사 }\end{array}$ & $\begin{array}{l}\text { 만 10세 이상 } \\
\text { 59세 이하 }\end{array}$ & 1년 & $\begin{array}{l}\text { 2019년 } \\
\text {-현재 }\end{array}$ & 3,000명 & $\begin{array}{c}\text { 성별·연령별. } \\
\text { 지역별 } \\
\text { 할당표집 }\end{array}$ & 횡단 \\
\hline & $\begin{array}{c}\text { 애니메이션 } \\
\text { 이용자 } \\
\text { 실태조사 }\end{array}$ & $\begin{array}{l}\text { 만 3세 이상 } \\
\text { 59세 이하 }\end{array}$ & 1년 & $\begin{array}{l}\text { 2019년 } \\
\text { - 현재 }\end{array}$ & 3,000명 & $\begin{array}{c}\text { 성별·연령별· } \\
\text { 지역별 } \\
\text { 할당표집 } \\
\end{array}$ & 횡단 \\
\hline & $\begin{array}{c}\text { 캐릭터이용자 } \\
\text { 실태조사 }\end{array}$ & $\begin{array}{l}\text { 만 3세 이상 } \\
\text { 59세 이하 }\end{array}$ & 1년 & $\begin{array}{l}\text { 2019년 } \\
\text { - 현재 }\end{array}$ & 3,000명 & \begin{tabular}{|c} 
성별·연령별· \\
지역별 \\
할당표집
\end{tabular} & 횡단 \\
\hline & $\begin{array}{l}\text { 게임이용자 } \\
\text { 패널연구 }\end{array}$ & $\begin{array}{c}\text { 1차년도(2014년) } \\
\text { 기준 초4, 중1, 고1 }\end{array}$ & \begin{tabular}{|l|} 
1년에 \\
2회
\end{tabular} & $\begin{array}{c}\text { 2014년- } \\
\text { 현재 }\end{array}$ & $\begin{array}{l}\text { 상반기 } 2,000 \text { 명 } \\
\text { 하반기 } 1,728 \text { 명 }\end{array}$ & 임의표집 & 종단 \\
\hline & $\begin{array}{l}\text { 게임이용자 } \\
\text { 실태조사 }\end{array}$ & $\begin{array}{l}\text { 만 10세 이상 } \\
\text { 65세 이하 }\end{array}$ & 1년 & $\begin{array}{c}\text { 2011년- } \\
\text { 현재 }\end{array}$ & $\begin{array}{l}\text { 이용자 2,165명 } \\
\text { 미이용자 } 919 \text { 명 }\end{array}$ & \begin{tabular}{|c} 
성별·연령별· \\
지역별 \\
할당표집
\end{tabular} & 횡단 \\
\hline & $\begin{array}{l}\text { 음악이용자 } \\
\text { 실태조사 }\end{array}$ & $\begin{array}{l}\text { 만 10세 이상 } \\
\text { 59세 이하 }\end{array}$ & 1년 & $\begin{array}{c}\text { 2019년- } \\
\text { 현재 }\end{array}$ & 3,000명 & \begin{tabular}{|c} 
성별·연령별· \\
지역별 \\
할당표집
\end{tabular} & 횡단 \\
\hline $\begin{array}{l}\text { 정보 } \\
\text { 통신 }\end{array}$ & $\begin{array}{c}\text { 지능정보사회 } \\
\text { 이용자패널 } \\
\text { 조사 }\end{array}$ & $\begin{array}{l}\text { 만 17세 이상 } \\
\text { 64세 이하 }\end{array}$ & 1년 & $\begin{array}{c}\text { 2018년- } \\
\text { 현재 }\end{array}$ & 4,233명 & $\begin{array}{c}\text { 성별·연령별· } \\
\text { 지역별 } \\
\text { 할당표집 }\end{array}$ & 종단 \\
\hline
\end{tabular}




\begin{tabular}{c|c|c|c|c|c|c|c}
\hline 언론 & $\begin{array}{c}\text { 언론수용자 } \\
\text { 조사 }\end{array}$ & 만 19세 이상 & 1년 & $\begin{array}{c}1984 \text { 년- } \\
\text { 현재 }\end{array}$ & 5,010명 & $\begin{array}{c}\text { 다단계 층화 } \\
\text { 집락 확률표집 }\end{array}$ & 횡단 \\
\hline 사회 & $\begin{array}{c}\text { 국민생활시간 } \\
\text { 조사 }\end{array}$ & 만 10세 이상 & 5년 & $\begin{array}{c}1980 \text { 년- } \\
\text { 현재 }\end{array}$ & 3,408 명 & $\begin{array}{c}\text { 다단계 층화 } \\
\text { 집락 확률표집 }\end{array}$ & 횡단 \\
\hline
\end{tabular}

자료: 한국콘텐츠진흥원(2020), 2020 웹소설이용자실태조사;

한국콘텐츠진흥원(2020), 2020 만화이용자실태조사;

한국콘텐츠진흥원(2020), 2020 애니메이션이용자실태조사;

한국콘텐츠진흥원(2020), 2020 캐릭터이용자실태조사;

한국콘텐츠진흥원(2018), 게임이용패널 5 차년도 연구;

한국콘텐츠진흥원(2020), 2020 게임이용자실태조사;

한국콘텐츠진흥원(2020), 2020 음악이용자실태조사;

방송통신위원회(2019), 지능정보사회 이용자 페널데이터 구축 및 조사;

한국언론진흥재단(2020), 2020 언론수용자조사;

서울대학교 언론정보연구소(2015), 2015 국민생활시간조사 자료 재정리

\section{나. 주요 조사통계 프레임}

- 콘텐츠 이용자를 대상으로 한 주요 조사통계 자료들은 대부분 '콘텐츠 이용행태' 중심의 정보를 수집하는 프레임을 갖추고 있음

- 콘텐츠 이용행태는 소비자 선택 매커니즘에 대한 기초적인 이론틀로 활용되는 시 간할당론에 기반하여, '시간, '기기', '지출' 관련 정보를 측정하도록 구성됨

- 자료별로는 세부적인 측정방식과 내용에 차이가 많음

- 콘텐츠 이용과 상관관계, 또는 인과관계를 검토할 수 있는 정보로는 콘텐츠 이용 만족도, 일반적인 삶의 질, 콘텐츠 관련 정책 등이 수집되고 있었으나, 구성 여부나 내용, 측정 방식은 자료별로 매우 상이함

- 자료별로 주요 조사 용어의 차이도 큰 편으로 확인됨

\section{4. 전문가 자문 분석 결과}

\section{가. 분석 개요}

- 콘텐츠 이용자를 대상으로 생산되고 있는 주요 데이터들의 현황, 주요 조사통계 자료들의 설계 구조와 프레임을 분석한 결과를 기반으로, 향후 콘텐츠 이용양상과 변화를 체계적으로 검토할 수 있는 데이터 구축 방안에 대해 전문가 자문을 진행함 


\section{나. 주요 결과}

- 현재 공공, 민간 영역에서 다양한 형태의 콘텐츠 이용자 데이터가 생산되고 있으 나, 콘텐츠 이용양상을 종합적으로 파악하고 분석할 수 있는 데이터가 부재함

- 대표성을 갖춘 조사통계 구축의 필요성

- 무엇보다 공공영역에서는 대표성을 갖추고, 콘텐츠 이용 지형과 양상을 종합적 으로 조망할 수 있는 조사통계를 구축하여 중심 데이터로 기능할 필요성이 제기 됨

- 측정 차별성

- 기존 자료들과 중첩되지 않는 가장 큰 차별성은 '콘텐츠산업 특수분류체계'를 최대한 활용하는 것이며, 통계법상 분류체계가 변경된다면 그 흐름에 최대한 맞 추도록 관리하는 것이 자료 이용자들에게 안정적임

- 콘텐츠 분야에서 그동안 상대적으로 측정이 소홀했던 ‘공연’ 분야가 급속히 온 라인화되고 있다는 점을 고려하여 장기적으로 계속 측정할 수 있도록 설계할 필요가 높음

- 콘텐츠 이용행동 분류를 너무 세밀하게 구분하면 측정 가능성이 낮아지므로, 지 양하는 편을 추천함

- 콘텐츠 이용자들의 이용행태와 인식, 정책 정보를 함께 수집할 수 있도록 구성

- 조사 범위 확장

- 콘텐츠 이용자 조사 범위는 가능한 한 최대 범위로 확장하되, 특히 최고 연령에 제한을 두지 않도록 하고, 미성년의 경우 별도의 방법론을 적용하거나 별도 조 사로 분리해야 함

- 특히 현실적으로 1 개 이상의 콘텐츠를 전혀 사용하지 않는 집단을 구분하기 어 렵고, 특정 콘텐츠만 이용하는 집단(마니아 집단) 등에 대한 파악이 부족한 상황 이므로, 초기 표본설계는 '전국민 인구를 대상으로 무작위 표본추출'을 하는 것 이 적절하다는 의견이 많았음

- 조사 주기는 1 년이 적합하며, 기본적으로 조사 예산과 인력 등을 충분히 지원하 여 향후 보다 정밀한 조사를 개발할 때 주기 간격을 보다 좁히는 것이 좋음

- 혼합조사방법론 적용 및 다이어리 조사 개발 등에 요구되는 예산, 인력 등 지원 


\section{5. 결론}

\section{가. 콘텐츠 이용자 데이터 구축의 방향성}

- 본 연구는 우리나라 콘텐츠 산업이 세계적인 성장과 변화를 주도하는 최전선에 있 고, 콘텐츠 생산과 소비 간의 상호영향 관계가 더욱 밀접해진 현실에서, 산업적 영 향력이 증대한 콘텐츠 이용자에 대한 체계적인 분석을 위해 콘텐츠 이용자 데이터 개발의 필요성을 제기함

- 현재 콘텐츠 산업계에서는 이용자 층위에서 다양한 데이터가 생산되고 있으나, 콘 텐츠에 대한 관점이 서로 다름으로 인해, 매우 다양한 방법으로 범주를 설정함으로 써 자료 간 상대 비교가 어려운 편임

- 또한, 콘텐츠 이용자를 대상으로 축적된 데이터들은 콘텐츠 산업 현장에서는 수익 증대에 직결될 정도로 가치가 상승하였으나, 콘텐츠 이용자들의 이용양상을 검토 할 수 있는 데이터에 대한 접근성은 매우 제한적임

- 콘텐츠 이용자 대상의 데이터는 조사통계 자료 중심의 정형데이터, 로그데이터, 빅데이터에 이르기까지 매우 다양함

〈표〉 콘텐츠 이용자 데이터 현황 및 특성 분석결과

\begin{tabular}{|c|c|c|c|}
\hline 구분 & 조사통계 & 로그데이터 & 빅데이터 \\
\hline 형태 & - 정형데이터 & - 반정형데이터 & - 비정형데이터 \\
\hline 장점 & $\begin{array}{l}\text { - 대표성(국가승인통계) } \\
\text { - 편의성(실태조사 등) }\end{array}$ & $\begin{array}{l}\text { - 정밀 분석이 가능한 정보 } \\
\text { 수집 }\end{array}$ & $\begin{array}{l}\text { - 시의성 } \\
\text { - 저비용 }\end{array}$ \\
\hline 단점 & $\begin{array}{l}\text { - 이용행태 파악에 제한점 있음 } \\
\text { (비용, 전문성 필요) }\end{array}$ & - 정보 접근성 & - 대표성이나 정확성 취약 \\
\hline 비용 & $\begin{array}{l}\text { - 표본 대표성이 확보될수록 고 } \\
\text { 비용 }\end{array}$ & - 고비용 & - 상대적으로 저렴 \\
\hline $\begin{array}{l}\text { 작성 소요 } \\
\text { 시간 }\end{array}$ & - 예산, 방법론에 따라 차이 & - 매우 신속 & - 보통 \\
\hline $\begin{array}{l}\text { 주요 활용 } \\
\text { 목적 }\end{array}$ & $\begin{array}{l}\text { - 정보의 지속적인 축적 } \\
\text { - 체계적인 분석 }\end{array}$ & $\begin{array}{l}\text { - 시의적인 기술통계치 } \\
\text { 파악 }\end{array}$ & $\begin{array}{l}\text { - 이용행태 및 상호작용 분석 } \\
\text { - 기업 수익 증대 및 마케팅 } \\
\text { 목적 }\end{array}$ \\
\hline
\end{tabular}


- 공공 영역에서는 현재 주로 조사통계 자료가 생산되고 있으나, 콘텐츠 이용자를 대상으로 한 조사의 절대량 자체가 매우 부족한 상황임

- 로그데이터나 빅데이터는 주로 민간 영역에서 생산되고 있는데, 일반 정보 이용자 의 접근성이 매우 제한적임

- 콘텐츠 이용자 빅데이터는 일반적으로 접근성이 용이한 SNS 데이터를 활용하 는 사례가 가장 대표적이며, 그 외에도 빅데이터 ISP를 세부분야별로 수립하여, 그동안 잘 활용되지 못했던 공공데이터를 발굴, 체계화하려는 노력이 있음

- 이러한 현황을 고려할 때, 본 연구에서는 향후 콘텐츠 이용자를 체계적으로 분석할 수 있는 기초적인 데이터 기반을 강화하기 위해, 콘텐츠 이용양상을 종합적으로 수집, 검토, 분석할 수 있는 콘텐츠 이용자 조사 개발을 우선적으로 제안함

\section{나. 콘텐츠 이용자 조사 구축}

- 콘텐츠 이용자 조사는 콘텐츠 이용자 층위에서 생산되고 있는 다양한 데이터들 가 운데, 콘텐츠 이용양상에 대한 심층적인 자료의 축적과 장르 간 상호 비교가 가능 한 자료를 구축하기 위해 필요함

- 조사통계의 최대 강점이 대표성에 있고, 특히 콘텐츠 분야에서 최근 다양한 종 류의 이용자 데이터 흔적(data trace)를 활용한 빅데이터의 활용도 활발한 추세 에 있다는 점을 고려하면, 콘텐츠 이용자 조사는 가능한 한 표본의 대표성과 내 용 측면에서 차별성을 갖출 필요성이 높음

- 대표성을 갖춘 콘텐츠 이용자 조사를 구축하기 위해서는 무엇보다 일반 사회 인구 구성을 반영한 표본설계가 중요함

- 시의성을 갖춘 콘텐츠 이용자 조사는 콘텐츠 이용 트렌드 변화 속도가 빨라, 이 를 계절별, 또는 반기별로 파악하여, 시장의 민감성이나 이용자의 관습적인 이 용행태의 변화 정보를 파악하기 위함임

- 시의성 자체를 주 목적으로 한다면, 조사통계 자료보다 대표성이 다소 부족하더 라도 비정형 빅데이터 중심의 여론 및 반응 데이터 활용이 더 효율적일 수 있음

- 콘텐츠 이용양상을 종합적으로 조사하는 안은 다음과 같이 제안함

- 콘텐츠 이용자 조사의 분류체계는 이용자 관점에서의 현실적인 콘텐츠 이용여 
부 가능성과 미래 성장 가능성을 고려하여, '출판, 만화, 애니메이션, 캐릭터, 게임, 영화, 방송, 음악, 공연' 9개로 구분함

- 조사목적은 '우리나라 국민의 콘텐츠 이용 현황과 인식을 종합적으로 파악하여, 향후 콘텐츠 산업 정책 수립에 기초자료로 활용하기 위함임

- 조사대상은 시작 연령은 만 10 세 이상으로 설정하되, 연령 상한선에 제한을 두 지 않도록 함

- 조사방법은 현재, 대면조사나 온라인 조사가 모두 가능하도록 설계하였음

- 조사 프레임은 다음과 같이 제시함(구성 이유는 본문, 조사지는 부록 참조)

〈표〉 콘텐츠 이용자 조사 프레임 안

\begin{tabular}{|c|c|}
\hline 구분 & 내용 \\
\hline $\begin{array}{l}\text { 응답자 일반현황 } \\
\text { (사회경제적 요인) }\end{array}$ & 성, 연령, 지역, 학력, 경제활동여부, 소득, 직업, 가구유형 \\
\hline 콘텐츠 이용 경험 & $\begin{array}{l}\text { - 콘텐츠 이용 장르 } \\
\text { - 콘텐츠 주 이용 기기 } \\
\text { - 콘텐츠 이용 장르별 평균 이용시간(평일, 주말 구분 시간일지) } \\
\text { - 콘텐츠를 주로 이용하는 장소 } \\
\text { - 콘텐츠 이용 상황(혼자, 함께 이용하는 사람) } \\
\text { - 콘텐츠 장르별 유료결재 경험 및 금액 } \\
\text { - 콘텐츠 지출 내용(콘텐츠 서비스, 어플리케이션, 관련 상품 구매) }\end{array}$ \\
\hline 콘텐츠 이용 인식 & $\begin{array}{l}\text { - 관련 정책 및 사회적 이슈 } \\
\text { (문화가 있는 날, 주52간제, 할인 혜택 및 무료 이용, } \\
\text { 개인정보보호, 셧다운 제도, 성인지 감수성) } \\
\text { - 평소 삶의 만족도 } \\
\text { - 평소 건강 }\end{array}$ \\
\hline
\end{tabular}

\section{다. 콘텐츠 이용자 행동 데이터 활용 방안}

- 콘텐츠 이용자 층위에서는 $\mathrm{PC}$ 나 스마트폰과 같이 콘텐츠 이용과 밀접한 사용관계 에 있는 특정 기기에 특화된 이용정보를 수집할 수 있음

- 로그 데이터는 기기 기반의 이용 정보를 수집하는 별도의 소프트웨어를 통해, 정보 제공과 설치 동의가 허락된 이용자들의 웹로그 기록을 수집, 가공하여, 최종적으로 이용자들의 특정 서비스에 대한 행동 분석이 가능함

- 이러한 로그데이터는 대부분 현재 민간 기업 내부에서는 비교적 활발하게 활용 
될 수 있으나, 외부에서의 접근 가능성은 매우 제한적임

- 현재 국내 거주자를 무작위 층화추출하여, PC 및 모바일 운영체제별 사용자 패 널을 대상으로 실시간 수집 로그 데이터를 활용하고 있는 시례가 확인됨

- 로그 데이터는 콘텐츠 이용행태를 장르별, 채널별, 프로그램별, 상품별, 플랫폼 별로 매우 구체적으로 구분하여 파악할 수 있다는 장점이 있음

- 다만 이러한 로그 데이터를 활용한 행동 분석은 기업이 내부적으로 보유한 데이 터를 활용한 행동 분석과는 내용상 차이가 있음

- 콘텐츠 이용자들의 행동 패턴이 매우 복잡하고, 콘텐츠를 이용하는 기기나 채널, 플랫폼 등 서비스 경로 또한 매우 다양한 상황에서, 이러한 조사통계, 로그 데이터, 그리고 SNS 텍스트 데이터나 구매 행동 데이터 등에 이르는 비정형 빅데이터를 다양하게 활용할 가치는 높음

- 일반적으로 '빅데이터’라고 불리는 비정형 데이터는 콘텐츠 이용자들이 생산하 는 SNS나 블로그, 커뮤니티 등 공개 메시지 형태가 대표적임

- 이러한 종류의 빅데이터는 시의성이나 분석 목적, 맥락 등이 매우 중요함

- 콘텐츠 커뮤니티를 중심으로 한, 특정 주제 분석에 적극 활용할 가치가 있음

- 실제로 팬덤 등 특유의 행동 분석을 진행한 시례들도 다수 확인됨

- 텍스트 데이터 외에 영상 데이터로 확장하더라도, 유튜브, 네이버 TV 캐스트 등 콘텐츠가 생산되는 개별 사이트별로 이용 행동 분석, 감성 분석 등 다양한 형태의 기획이 가능함(이호영 외, 2019)

- 그 외에도 활용할 수 있는 빅데이터 자원은 기획 내용에 따라 매우 다양할 수 있고, 콘텐츠 특성상 각 분야별 특수성이 있어, 정보전략계획 수립 등 별도의 연구가 요구됨 


\section{목차}

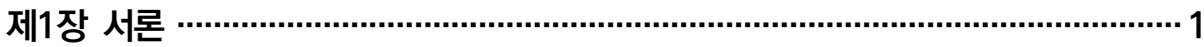

제1절 연구 배경 및 목적 3

1. 연구 배경 3

2. 연구 목적 6

제2절 연구 범위 및 방법 1

1. 연구 범위 7

2. 연구 방법 9

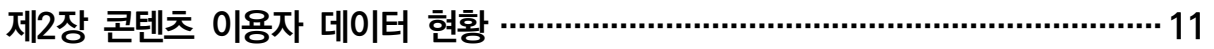

제1절 콘텐츠 이용자의 정의와 범주 13

1. 콘텐츠 이용자에 대한 정의 13

2. 콘텐츠 이용의 범주 17

제2절 콘텐츠 이용자 대상 데이터 현황 19

1. 정형 데이터 19

2. 비정형 데이터 21

제3절 시사점 25

1. 콘텐츠 이용자에 대한 체계적인 이해의 필요성 25

2. 콘텐츠 이용에 대한 정의와 범주의 다양성 26

3. 콘텐츠 이용자 데이터의 이질성 29

제3장 콘텐츠 이용자 대상 주요 데이터 분석 …………………………………3

제1절 주요 조사통계 표본설계 및 프레임 35

1. 국가승인통계 35

2. 주요 실태조사 47 
제2절 시사점 60

1. 대표성을 갖춘 표본설계의 중요성 60

2. 콘텐츠 이용행태 측정 프레임의 다양성 63

3. 콘텐츠 이용 인과관계 측정 가능성 확대 65

4. 조사 용어 정비의 필요성 67

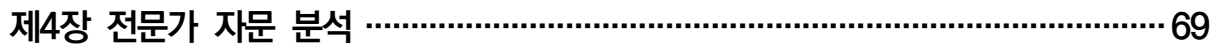

제1절 분석 개요 71

1. 분석 목적 71

2. 분석 방법 71

제2절 분석 결과 73

1. 콘텐츠 이용자 조사의 필요성 73

2. 콘텐츠산업 특수분류체계 기반의 정보 수집 74

3. 조사대상 범위의 확대 76

4. 예산과 인력을 고려한 조사주기 설정 77

5. 혼합조사방법론 적용 78

6. 인식 정보 수집의 가치 79

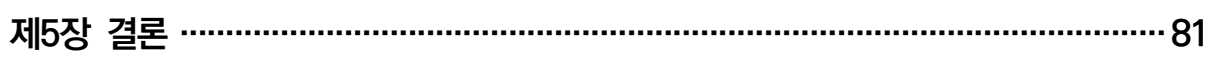

제1절 콘텐츠 이용자 데이터 구축의 방향성 83

1. 콘텐츠 이용자 데이터 개발 방안 83

2. 콘텐츠 이용자 조사 구축 86

제2절 콘텐츠 이용자 조사안 92

1. 콘텐츠 이용자 조사 분류체계 92

2. 콘텐츠 이용자 조사 프레임 94

제3절 콘텐츠 이용자 행동 데이터 활용 104

1. 로그 데이터 104

2. 빅데이터 105

참고문헌 / 107

ABSTRACT / 111

부록 / 113 


\section{표 목차}

〈표 2-1〉미디어(매체) 발전과 이용자 개념의 변화

〈표 2-2〉 콘텐츠 이용자 대상 빅데이터 활용 및 관련사업 추진 현황 24

〈표 2-3〉 해외 주요 조사의 콘텐츠 이용 범주 27

〈표 2-4〉 우리나라 주요 조사의 콘텐츠 이용 범주 28

〈표 2-5〉 콘텐츠 이용자 대상 생산 데이터 현황 29

〈표 3-1〉 국민문화예술활동조사 조사표 35

〈표 3-2〉 국민문화예술활동조사(구, 문화향수실태조사) 프레임 36

〈표 3-3〉 국민여가활동조사 조사표 37

〈표 3-4〉 국민여가활동조사 프레임 38

〈표 3-5〉 생활시간조사 조사표 39

〈표 3-6〉 생활시간조사 프레임 40

〈표 3-7〉 한국미디어패널조사 조사표 41

〈표 3-8〉 한국미디어패널조사 구성 41

〈표 3-9〉 한국미디어패널조사- 가구조사 프레임 41

〈표 3-10〉 한국미디어패널조사- 개인조사 프레임 42

〈표 3-11〉 인터넷이용실태조사 조사표 43

〈표 3-12〉 인터넷이용실태조사 - 가구조사 프레임 43

〈표 3-13〉 인터넷이용실태조사 - 개인조사 프레임 44

〈표 3-14〉 방송매체이용행태조사 조사표 45

〈표 3-15〉 방송매체이용행태조사 - 가구조사 프레임 45

〈표 3-16〉 방송매체이용행태조사 - 개인조사 프레임 46

〈표 3-17〉 청소년 매체이용 및 유해환경 실태조사 조사표 46

〈표 3-18〉 청소년 매체이용 및 유해환경 실태조사 프레임 47

〈표 3-19〉 웹소설이용자실태조사 조사표 48

〈표 3-20〉 웹소설이용자실태조사 프레임 48

〈표 3-21〉 만화이용자실태조사 조사표 49

〈표 3-22〉 만화이용자실태조사 프레임 49 
〈표 3-23〉 애니메이션이용자실태조사 조사표 50

〈표 3-24〉애니메이션이용자실태조사 프레임 51

〈표 3-25〉 캐릭터이용자실태조사 조사표 51

〈표 3-26〉 캐릭터이용자조사 프레임 52

〈표 3-27〉 게임이용자패널연구 조사표 52

〈표 3-28〉게임이용자패널조사 프레임 53

〈표 3-29〉게임이용자실태조사 조사표 54

〈표 3-30〉게임이용자실태조사 프레임 54

〈표 3-31〉 음악이용자실태조사 조사표 55

〈표 3-32〉 음악이용자실태조사 프레임 55

〈표 3-33〉 지능정보사회이용자패널조사 조사표 56

〈표 3-34〉 지능정보사회이용자실태조사 프레임 57

〈표 3-35〉언론수용자조사 조사표 57

〈표 3-36〉 언론수용자조사 프레임 58

〈표 3-37〉 국민생활시간조사 조사표 59

〈표 3-38〉 KBS 국민생활시간조사 프레임 59

〈표 3-39〉 콘텐츠 이용자 대상 주요 국가승인통계 61

〈표 3-40〉 콘텐츠 이용자 대상 주요 실태조사(비승인통계) 62

〈표 3-41〉 콘텐츠 이용자 대상 주요 조사통계 표본의 특징 63

〈표 3-42〉 콘텐츠 이용자 대상 조사 용어의 혼용 사례 68

〈표 4-1〉 자문위원 목록 72

〈표 4-2〉 자문 구조 $\quad 72$

〈표 5-1〉 콘텐츠 이용자 데이터 현황 및 특성 분석결과 84

〈표 5-2〉 우리나라 사회인구학적 요인별 콘텐츠 이용행태 현황 85

〈표 5-3〉 조사통계 자료배열 구조 87

〈표 5-4〉 콘텐츠 이용자 주요 조사통계 현황 88

〈표 5-5〉 갈퀴법 통계보정 사례 89

〈표 5-6〉 대표성을 갖춘 콘텐츠 이용자 조사 개발안 90

〈표 5-7〉 시의성을 갖춘 콘텐츠 이용자 조사 개발안 90

〈표 5-8〉 콘텐츠 이용 분류안 93

〈표 5-9〉 콘텐츠 이용자 조사 프레임 안 95 


\section{그림 목차}

[그림 1-1] 연구의 수행방법 및 과정 9

[그림 2-1] 디지털 경제 구조와 콘텐츠 이용 주체의 탐색 14

[그림 2-2] 디지털 경제 생산, 거래, 소비 구조의 특징적 변화와 사례 14

[그림 2-3] 해외 주요 국가의 콘텐츠산업(문화산업) 특수분류체계 범주 17

[그림 2-4] 로그 데이터: 정형·반정형·비정형 데이터 비교 22

[그림 2-5] 넷플릭스 이용자 성향분석 목적 빅데이터 종류 23

[그림 2-6] 콘텐츠 이용자 정보 가치 부상 26

[그림 2-7] PC 및 모바일 이용자 대상 로그데이터 수집 과정 30

[그림 5-1] 콘텐츠 분야 로그 데이터 활용 자료 105 

콘텐츠 이용자 데이터 개발 기반연구

\section{제1장}

서론 



\section{제1절 연구 배경 및 목적}

\section{1. 연구 배경}

\section{가. 콘텐츠 이용자의 위상 제고}

- 콘텐츠 산업은 생산과 소비의 기반이 되는 기술, 기기, 서비스 방식 등 다측면에서 빠른 발전과 변화를 거듭하고 있음

- 콘텐츠 이용자들은 수동적인 수용자에 머무르지 않고, 콘텐츠 선택의 폭을 넓히며, 콘텐츠 산업 간 융합을 촉진하게 할 뿐만 아니라 그 변화 속도에도 민감하게 영향 을 미치고 있음

- 콘텐츠 이용자들의 선호도, 취향, 가치관, 또는 콘텐츠를 포함한 관련 소비의 구매력 등 다양한 요소들이 콘텐츠 제작 및 유통 등 기업의 수익 발생에 직접적 인 영향을 줄 수 있을 정도로 산업 생태계에서의 위상이 제고됨

- 실제로 콘텐츠 이용자들은 최근으로 올수록 콘텐츠 생산 측면에 더욱 빠른 속도 로 즉각적인 피드백 정보를 제공하며 큰 영향을 주고 있음

- 콘텐츠 산업의 지속적인 진흥을 위해서는 이제 생산, 제작, 유통 등 전통적인 콘텐 츠 생산 각 단계의 핵심 역량을 높이는 것 외에도, 콘텐츠 이용자들의 변화 양상을 지속적으로 축적하고 검토하여, 그 결과를 산업계가 중장기적인 전략 수립에 반영 하고, 활용할 수 있는 기반을 강화해야 함

- 콘텐츠 정책 측면에서도 콘텐츠 이용자들의 변화 양상과 그 요인에 대한 심층적인 이해도를 높여, 콘텐츠의 생산과 유통, 소비 등 산업의 전반적인 관계를 상호 고려 한 정책을 수립하고, 점검해야 할 필요성이 높음 


\section{나. 콘텐츠 이용자 대상 데이터 생산 현황과 한계}

- 콘텐츠 이용자들의 변화 양상을 체계적으로 이해하기 위해서는 무엇보다 콘텐츠 이용자 층위에서의 데이터 구축과 지속적인 분석이 필요함

- 특히 콘텐츠의 특성상 생산과 이용 양 측면은 기술이나 데이터와 매우 친화적인 관계에 있음(이호영 외, 2019). 이는 콘텐츠가 플랫폼 중심의 미디어 환경, 데 이터 기반의 기술과 기기, 사회 구조의 변화 등과 밀접한 관계를 맺고 있기 때문 임

- 콘텐츠 이용자들의 변화 양상을 파악하는데 활용할 수 있는 데이터들은 매우 다양 한 작성주체들에 의해, 다양한 형태로 생산되고 있음

- 현재까지는 공공영역에서는 주로 조사통계 자료를 중심으로, 민간영역에서는 비정형 빅데이터나 통계 자료들이 생산되고 있음

- 공공영역에서 생산되는 콘텐츠 이용자 층위에서의 조사통계 자료들은 콘텐츠 이용의 현실적인 동태를 종합적으로 파악하기가 어려운 편인데, 그 이유는 콘텐 츠에 대한 정의와 범주 설정의 방식이 작성주체에 따라 매우 이질적이라는 점에 기인하는 바가 큼

- 콘텐츠 이용양상의 변화를 체계적으로 이해하는데 있어서는 일부 대규모 콘텐츠 기업이 유리한 경향이 있음. 이와 대조적으로, 콘텐츠 이용자에 대한 정보를 체계 적으로 수집, 활용할 수 있는 현실적인 조건이 불리한 소규모 사업체들은 상대적으 로 콘텐츠 이용자들에 대한 정보 활용과 접근성이 제한되어, 정보 격차를 겪을 가 능성이 높음

- 콘텐츠 산업 생태계에서 콘텐츠 이용자 관련 데이터들을 적극적으로 활용하여, 전략 수립이나 수익 증대로 직결할 수 있는 역량이 사실상 플랫폼, 데이터 기반 서비스에 보다 밀접한 일부 기업들에 한정되어 있기 때문임

- 정책 측면에서도 콘텐츠 이용양상이나 구조를 체계적으로 파악할 수 있는 데이터 는 양적으로도 절대 부족한 상황이었기 때문에, 지금과 같이 장르별 이용양상을 보고하는 자료가 많이 생산되는 상황에서는 콘텐츠 이용을 보다 종합적인 관점에 서 검토할 수 있는 데이터가 필요함

- 콘텐츠 산업 정책의 주요부처인 문화체육관광부 또한 통계법상 콘텐츠산업 특 
수분류체계를 중심으로 관련 자료를 최대한 활용하더라도, 데이터 기반이 취약 함으로 인해 다른 부처나 일부 기업이 공개하는 자료에 대한 의존도가 높을 수 밖에 없었음

- 일례로 코로나 이후 대면 접촉이 제한되면서 오프라인 콘텐츠 이용이 감소하고, 플랫폼 기반의 온라인 콘텐츠 이용이 폭발적으로 증가한 것으로 파악되었으나, 이 또한 특정 기업들의 공개 자료에 대한 의존도가 높아, 관련 데이터를 보유한 기업 외부에서 신뢰성 있는 정보를 파악하거나 심층 분석을 진행할 수 있는 데 이터 구축의 필요성을 확인함

\section{다. 콘텐츠 이용양상과 인식 변화를 종합하는 데이터의 필요성}

- 콘텐츠 이용양상의 변화를 파악할 수 있는 이처럼 다양한 데이터들 중에서도, 콘텐 츠 장르 간 이용행태와 이용자들의 가치관, 취향 등 인식의 변화를 종합적으로 검 토할 수 있는 중심 데이터 구축이 필요한 상황임

- 이를 통해 산업계에는 안정성과 신뢰성을 갖춘 콘텐츠 이용자 정보를 제공하고, 동시에 정책적으로도 향후 콘텐츠 이용자를 대상으로 한 정책 수립의 근거 자료 기반을 강화할 수 있음

- 콘텐츠 이용양상을 파악할 수 있는 데이터들은 무엇보다 콘텐츠 전 장르를 종합적 으로 측정하지 못하고 있다는 한계가 있음

- 콘텐츠 이용을 여가나 미디어 기기 사용의 일부로 파악해 온 기존 통계자료들도 콘텐츠의 현실적인 이용행태를 제대로 반영하지 못한 한계가 있었음(문화체육 관광부, 2018; 한준 외, 2017)

- 플랫폼 서비스 차원에서 콘텐츠 이용 추이를 파악한 자료들도 콘텐츠 이용의 극히 일부를 범주로 설정해 온 측면이 있음

- 본 연구는 콘텐츠 이용자 층위에서 생산되어 온 기존 데이터들이 콘텐츠에 대한 서로 다른 관점과 기준에 의해 작성됨으로써 콘텐츠 산업과 이용자를 종합적으로 통찰하기 어려웠던 점에 주목하여, 콘텐츠 이용자를 대상으로 한 체계적인 데이터 개발의 필요성을 제기함 


\section{2. 연구 목적}

\section{가. 콘텐츠 이용자 데이터 생산 현황 파악}

- 본 연구는 우선 콘텐츠 이용자를 대상으로 생산된 기존 데이터 현황을 파악함 - 이를 통해 콘텐츠와 이용자에 대한 관점이나 작성주체에 따라 콘텐츠 이용양상 을 파약할 수 있는 방법이 달라질 수 있어, 콘텐츠 이용자에 대한 체계적인 데이 터가 생산될 필요성이 있음을 이해함

\section{나. 콘텐츠 이용자 대상 주요 조사통계 분석}

- 다음으로 콘텐츠 이용자를 대상으로 한 기존의 주요 조사통계 자료를 분석함 - 분석 범위를 조사통계 자료로 한정한 이유는 현재 공공영역에서 생산되고 있는 데이터의 주된 형태이기 때문임

- 이 과정에서 콘텐츠 이용자 대상 기존 조사통계 자료들의 표본설계 및 자료배 열, 내용 구조를 중점적으로 분석하여, 현황과 한계점을 파악함

- 나아가 향후 콘텐츠 장르 간 이용양상을 효율적으로 파악할 수 있는 중심 데이터 구축에 필요한 내용을 도출함. 이 결과에 기반하여, 콘텐츠 산업과 이용자에 대한 이해도가 높은 전문가들의 검토 의견을 수렴함

\section{다. 콘텐츠 이용자 조사안 도출}

- 최종적으로 콘텐츠 이용자 층위에서의 데이터 개발의 방안을 제시하고, 중심 데이 터로 역할을 수행할 수 있는 콘텐츠 이용자 조사안을 구체적으로 도출할 것을 목적 으로 함

\section{라. 콘텐츠 이용자 데이터 활용 방안}

- 그 외에도 빅데이터 등 콘텐츠 이용자 층위에서 활용 가능한 데이터 활용 방안을 제안함 


\section{제2절 연구 범위 및 방법}

\section{1. 연구 범위}

\section{가. 공간적 범위}

- 본 연구에서 다루는 콘텐츠 이용자 데이터 관련 내용의 공간적 범위는 국내로 설정함 - 콘텐츠 및 이용자에 대한 다양한 관점을 이해할 필요가 있는 경우, 일부 해외 문헌자료를 활용함

\section{나. 시간적 범위}

- 본 연구 분석의 주된 시간적 범위는 1999 년 이후 2021년 현재 시점으로 설정함 - 이는 연구 사전 검토단계에서, 콘텐츠 이용양상을 파악할 수 있는 통계 자료의 최초 설계 검토가 가능한 시점이 1999년으로 파악되었기 때문임

- 기존 주요 통계자료는 가능한 한 최신 생산 자료를 활용함

- 주요 분석 자료인 기존 조사통계 자료를 심층분석 시, 자료의 표본설계와 내용의 구조적 근간으로 활용된 이론적인 논의는 시점에 제한을 두지 않고 파약할 수 있도 록 함

\section{다. 내용적 범위}

- 본 연구는 첫째, 국내 중심으로 콘텐츠 이용자 데이터의 생산 현황을 파악함 - 우선 데이터 생산의 기초인 콘텐츠 및 이용자에 대한 정의와 범주, 이에 따른 측정 방법의 다양성을 이해하도록 함

- 또한 국내 시장의 데이터 생산 현황에 집중하여, 현재 콘텐츠 이용자를 대상으 
로 생산되는 데이터들이 콘텐츠와 이용자에 대한 정보를 어떻게 서로 다르게 다루고 있는지를 파악함

- 이를 통해 콘텐츠와 이용자에 대한 정보 수집과 활용 목적에 따라, 데이터의 생 산 형태와 내용에 차이가 발생할 수 있음을 이해함

- 이러한 배경에서, 콘텐츠 이용자 층위에서 안정적이고, 종합적인 정보를 활용하 고자 하는 데이터 수요 측면에서는 콘텐츠 이용자 정보에 대한 종합적인 접근과 자료 생산이 필요함을 제기함

- 둘째, 콘텐츠 이용자를 대상으로 한 기존의 주요 데이터들 가운데, 공공영역에서 생산된 주요 조사통계 자료를 심층 분석함

- 다양한 데이터들 가운데, 주요 심층분석 자료를 조사통계로 집중한 이유는 현재 공공영역에서 생산하는 주요 데이터의 형태이며, 동시에 데이터의 구조와 내용 양 측면에서 심층적인 분석이 가능하기 때문이기도 함

- 각 조사통계 자료 분석은 형태와 내용 분석을 중심으로 함. 형태 분석은 조사통 계의 표본설계 및 자료배열 구조를 중심으로, 내용 분석은 각 자료가 설계한 프 레임 구성을 중심으로 함. 특히 통계 프레임워크는 통계 작성의 주요 목적에 따 라, 각 변인들의 구성 뿐만 아니라, 측정 변인들 간의 구성, 즉 자료의 전반적인 구조와 의미를 파악하기 위함임

- 이처럼 각 자료의 특이점을 파악함으로써, 향후 콘텐츠 이용자들의 이용양상을 종합적으로 측정, 분석하는데 필요한 시사점을 도출하도록 함

- 셋째, 앞선 연구과정의 분석결과를 토대로, 콘텐츠 산업과 이용자들에 대한 이해도 가 높은 전문가들의 의견을 추가적으로 수렴함

- 이를 통해 향후 콘텐츠 이용자 데이터 개발시 유의해야할 점들에 대한 의견을 점검하고, 구체적으로 중심 데이터로서 조사 개발에 필요한 의견을 함께 수집하 고자 함

- 종합적으로, 이러한 연구 과정을 통해 향후 콘텐츠 이용자 층위에서 보다 더 다양 하고 유익한 양적 데이터들을 개발하기 위한 방향성을 제시하고, 구체적인 개발 방안을 도출함 


\section{2. 연구 방법}

- 본 연구의 주요 연구 방법은 문헌자료 분석과 전문가 자문임

- 콘텐츠 이용양상을 전반적, 또는 부분적으로 검토할 수 있는 기존의 기초통계 보고서, 관련 논문, 서적 등의 자료는 문헌 분석을 진행함

- 한편, 연구과정에서 콘텐츠 산업과 이용자에 대해 이해도가 높은 전문가들을 대 상으로, 차별성을 갖춘 콘텐츠 이용자 데이터 개발에 적합한 방법론과 내용에 대한 의견을 수렴하여, 향후 콘텐츠 이용자 데이터 개발을 위한 구체적인 방향 성과 안을 제시하도록 함

[그림 1-1] 연구의 수행방법 및 과정

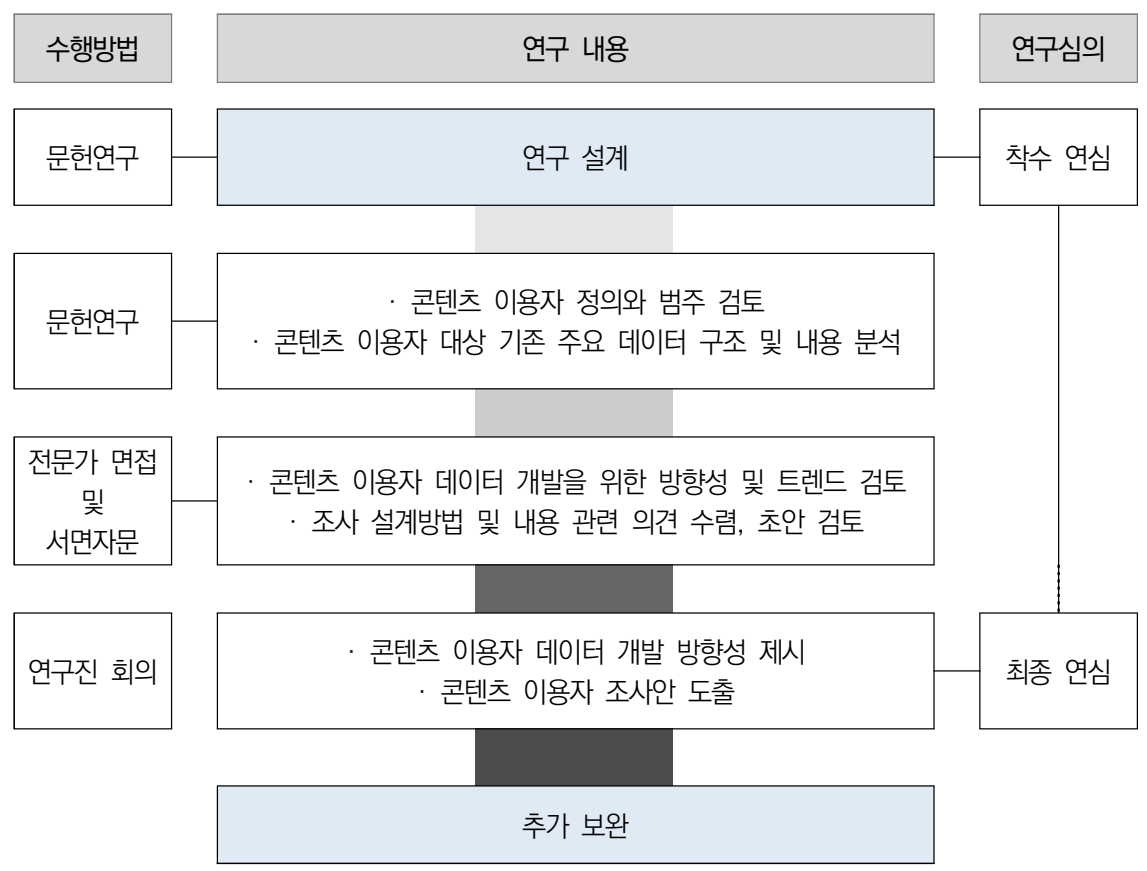



콘텐츠 이용자 데이터 개발 기반연구

제2장

콘텐츠 이용자 데이터 현황 



\section{제1절 콘텐츠 이용자의 정의와 범주}

\section{1. 콘텐츠 이용자에 대한 정의}

\section{가. 콘텐츠와 콘텐츠 산업}

- 본 연구의 핵심적인 대상인 '콘텐츠 이용자'에 대한 정의는 데이터 구축 초기 단계 에서 명확하게 규정될 필요가 있으나, 실제로 학술적으로나, 통상적으로 일정하게 규정된 바는 없음

- 이는 국내·외 '콘텐츠'와 '콘텐츠 산업'에 대한 정의가 일정하게 확립된 바가 없고, 다만 공통적으로 온·오프라인 유·무형의 정보, 문화, 오락, 그리고 이를 전달하는 물리적 기기에 이르기까지 다양한 형태를 포괄하고 있다는 특성과도 연관성이 있 음(김소연 외, 2020)

- '콘텐츠'에 대한 국내 정의는 〈콘텐츠산업진흥법〉과 〈문화산업진흥기본법〉에서 ‘부호, 문자, 도형, 색채, 음성, 음향, 이미지 및 영상 등의 자료 또는 정보'로 제시 하고 있음

- '콘텐츠 산업'에 대한 국내 정의는 통계작성을 목적으로 마련한 '콘텐츠 산업 특수 분류체계'가 12 개 세부 산업을 비교적 명확하게 구분하여 제시하고 있음

\section{나. 콘텐츠 이용}

- 콘텐츠와 콘텐츠 산업에 대한 정의가 이처럼 매우 엄격하게 규정되어 있지는 않아, 콘텐츠 이용에 대한 정의 또한 상대적으로 유연한 편이라 할 수 있음

- 원론적으로 콘텐츠 산업이 3차 산업혁명인 정보화 단계를 넘어, 인지혁명기로 설 명되는 4차 산업혁명 이행에 있어 차지하는 비중이 크다는 점을 고려하면, 콘텐츠 
이용의 주체는 기업, 가계(가구), 정부 또는 다양한 조직 및 개인에 이르기까지 다 양할 수 있음

[그림 2-1] 디지털 경제 구조와 콘텐츠 이용 주체의 탐색
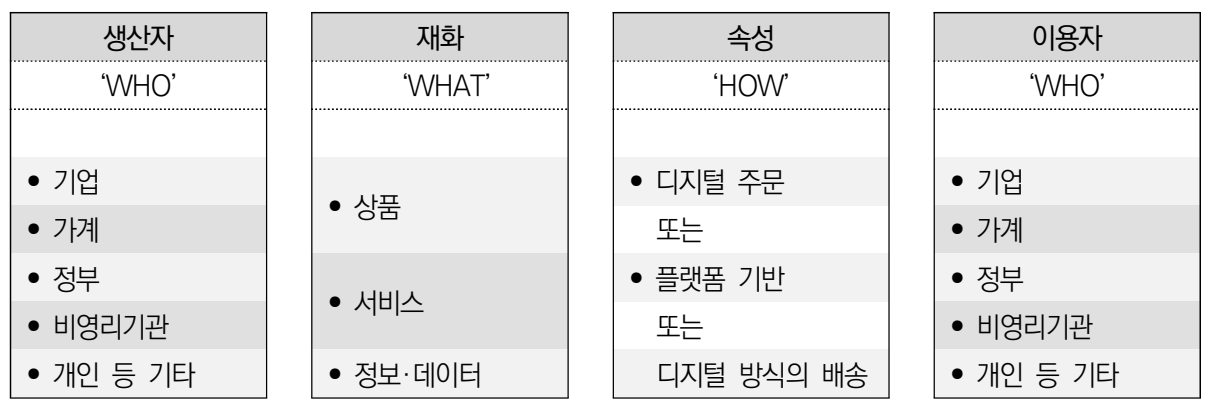

\section{기반 요소}

자료: Ahmad and Rbeosky(2018) 활용 재구성

- 이러한 가운데, '개인 또는 개인성'이 디지털 경제, 지능정보사회 구조에서 중요성 이 부상한 이유는 생산, 유통, 소비 일련의 모든 단계에 미치는 개인의 영향력이 증대하였기 때문임

- 특히 콘텐츠 이용에 있어서는 콘텐츠를 서비스하는 기업(사업체)의 서비스의 영 향력과 개인의 주체적 선택권 간의 문제에 대한 중요성이 빠른 속도로 높아짐 (이호영 외, 2019)

[그림 2-2] 디지털 경제 생산, 거래, 소비 구조의 특징적 변화와 사례

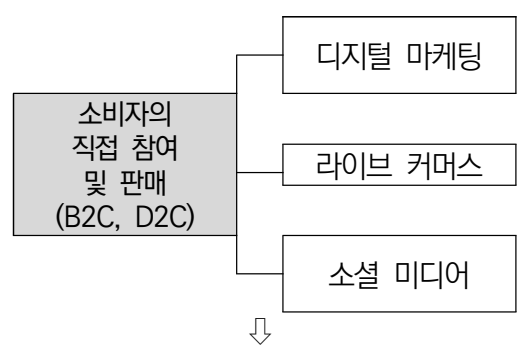

유통업체를 통하지 않고 제조업체가 소비자에게 직접 제품을 판매하는 '소비자직접판매(B2C, D2C)' 방식 부상

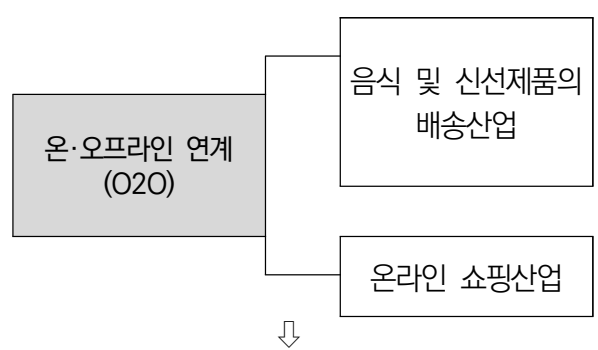

인터넷 기술이 생활서비스업에 빠르게 적용되면서

'온·오프라인 연계 서비스(O2O)' 성장

\section{개인 또는 개인성의 중요성 증대}

자료: 한국생산성본부 생산성연구소(2020), 포스트코로나 대응을 위한 한국판 뉴딜의 핵심전략 디지털뉴딜에서 재구성 
- '콘텐츠 이용'은 미디어 기기나 플랫폼 서비스 등을 통해 '디지털화된 산물(상품, 서비스 등)을 이용하는 개인의 이용행태'로 다뤄지는 경향이 있음

- 콘텐츠 이용을 미디어 이용과 거의 동등한 개념으로 접근하여, 인터넷, 온라인, 플랫폼 등 기기나 기술의 발전과 완전히 분리되지 않는 '사회문화적 행동' 으로 다룬 것임(Ajzen \& Fishbein, 1980; 송해룡, 2019)

- 이는 콘텐츠 이용이 기술이나 기기 등의 발전과 분리된 채 독립적으로 발생하기 힘들기 때문에, 콘텐츠가 전달되는 기술적 기반에 따른 문화적 가치, 경제적 가 치를 갖춘 ‘소비활동' 으로 이해되기도 함(조항민 외, 2019)

- 한편 콘텐츠 이용을 주로 '온라인, 모바일 환경에서 행해지는 여가활동' 으로 간주 하여, 오프라인 기반의 전통적인 여가활동과 구별하는 방식도 있음

- 여가활동은 학술적으로 '생활에서 모든 의무와 책임, 그리고 생활에 필요한 활 동, 즉 노동, 학습, 가사, 돌봄, 또는 수면이나 개인 유지, 이동 행위 등을 제외한 나머지 자유로운 시간인 동시에, 자기 자신을 찾을 수 있는 기회'로 다뤄짐 (Ermisch, 2000, Gershuny, 2019; 김성희·심상신, 2018)

- 본래 여가는 문화예술, 체육, 관광, 교제, 종교 활동 등의 폭넓은 활동을 모두 포괄하는 개념으로, $\mathrm{TV}$, 라디오 등의 전통적인 미디어를 이용한 콘텐츠 이용과 스마트기기, 인터넷이 결합된 뉴미디어를 이용한 콘텐츠 이용을 모두 포함하나, 그 내용은 작성주체에 따라 다양함(Gershuny, 2019)

\section{다. 콘텐츠 이용자}

- 이처럼 콘텐츠와 콘텐츠 산업, 그리고 콘텐츠 이용에 대한 정의 방식이 다양하여, 콘텐츠 이용자에 대한 정의를 한 가지로 명확하게 정립하는 것은 원천적으로는 어 려움

- '콘텐츠를 이용하는 사람'에 대해 가장 많은 연구를 축적하고 있는 커뮤니케이션학 에서도 기기나 매체의 발전에 따라 변화하는 개인들을 '콘텐츠 이용자'로 간주해왔 으나, 구체적인 방법은 다양함(송해룡, 2019)

- 콘텐츠와 아주 밀접한 개념인 '미디어 이용자'에 대한 정의 또한 명확하게 규정 된 바가 없으나, 일반적으로 언론이나 대중문화 등 매체를 이용하는 사람들로 
다뤄지고 있다는 점을 참고할 가치가 있음(이호영 외, 2019)

- 최근에는 미디어 기기나 플랫폼 서비스들이 더욱 다양해지고, 이용자들의 이용 양상 또한 복잡해지면서, 미디어 발전의 역사를 고려한 이용자 개념 정립이 시 도된 바 있음. 즉 미디어 기기 뿐만 아니라, 다양한 플랫폼 및 서비스를 이용하 는 주체가 '다중매체 이용자, 소비자, 디지털 주민'이라는 개념에 이른다는 것인 데, 이는 콘텐츠보다는 정보통신 기술이나 기기, 파생 서비스 발전에 더 주목한 방식임

〈표 2-1〉미디어(매체) 발전과 이용자 개념의 변화

\begin{tabular}{|c|c|c|c|c|}
\hline $\begin{array}{l}\text { 미디어 } \\
\text { 발전 }\end{array}$ & $\begin{array}{c}\text { 주요 매체 서비스 } \\
\text { 흐름 }\end{array}$ & $\begin{array}{l}\text { 주요 } \\
\text { 기능 } \\
\end{array}$ & 주요 사안 & $\begin{array}{l}\text { 집합적 } \\
\text { 주체 }\end{array}$ \\
\hline $\begin{array}{l}\text { 신문, 라디오, } \\
\text { 방송(지상파), } \\
\text { 옥외광고 }\end{array}$ & $\begin{array}{l}\text { 신문구독, 공영방송 시청, } \\
\text { 전광판, 선거방송 }\end{array}$ & $\begin{array}{l}\text { 여론 } \\
\text { 형성 }\end{array}$ & $\begin{array}{l}\text { ·공적 사안의 인지 및 참여 } \\
\text { ·신뢰, 관용, 예절 등 미덕을 갖춘 정도 }\end{array}$ & 공중 \\
\hline $\begin{array}{l}\text { 인터넷 } \\
\text { 모바일 }\end{array}$ & $\begin{array}{c}\text { 공공 와이파이, 알뜰폰, } \\
\text { 인터넷 사생활보호, } \\
\text { 올림픽 국가대표 경기관람 }\end{array}$ & $\begin{array}{l}\text { 권리 } \\
\text { 주창 }\end{array}$ & $\begin{array}{l}\cdot \text { 서비스 대비 가격의 합리성 } \\
\cdot \text { 사생활 등 인격권 보호 정도 }\end{array}$ & 시민 \\
\hline 방송(비 지상파) & $\begin{array}{l}\text { 지상파 기획 및 편성, } \\
\text { 공연 및 영화 }\end{array}$ & $\begin{array}{l}\text { 기획 } \\
\text { 대상 }\end{array}$ & $\begin{array}{l}\text { ·특정 내용에 대한 관심 정도 } \\
\text { ·시간대 별 매체 이용현황 } \\
\text { ·최대 동원 가능 청중 규모 }\end{array}$ & $\begin{array}{l}\text { 수용자 } \\
\text { (청중) }\end{array}$ \\
\hline $\begin{array}{c}\text { 플랫폼 } \\
\text { 온라인 동영상 } \\
\text { 서비스(OTT) }\end{array}$ & $\begin{array}{l}\text { 다중 매체, } \\
\text { 다중 플랫폼, } \\
\text { 다채널 서비스 }\end{array}$ & $\begin{array}{l}\text { 정보환경 } \\
\text { 구성 }\end{array}$ & $\begin{array}{l}\text { ·다양성: 최대 이용 서비스의 수 } \\
\text { ·동시성: 동시 이용 서비스의 수 } \\
\text { ·사회성: 사회적 이용 정도 } \\
\text { ·충족성: 동기 실현 내용 }\end{array}$ & $\begin{array}{l}\text { 다중 } \\
\text { 매체 } \\
\text { 이용자 }\end{array}$ \\
\hline 인공지능(Al) & $\begin{array}{c}\text { 모든 종류의 유료매체 } \\
\text { 서비스 }\end{array}$ & $\begin{array}{l}\text { 서비스 } \\
\text { 계약 }\end{array}$ & $\begin{array}{l}\text { ·최대 지불능력, 평균 지불능력 } \\
\text { ·계약 변경 빈도 } \\
\text { ·무료 서비스 이용 비중 }\end{array}$ & 소비자 \\
\hline
\end{tabular}

자료: 이호영 외(2019)에서 재구성

- 이러한 점을 고려할 때, 본 연구의 주요 목적인 콘텐츠 이용자 데이터 개발 방안을 도출하기 위해서는 '콘텐츠 이용자'를 통계법상 콘텐츠산업 특수분류체계가 구분 하는 콘텐츠를 이용하는 사람으로 구체화할 필요가 있음

- 이는 '미디어 활동(사회문화적, 소비활동 등)'이나 '여가활동'에 대한 정량 자료 구축과 측정을 위해 정립된 미디어 이용자나 여가활동의 주체에 대한 정의와 차별성이 있음 


\section{2. 콘텐츠 이용의 범주}

\section{가. 해외 콘텐츠 이용 범주}

- 콘텐츠에 대한 정의가 국가별, 지역별, 작성기관별로 다양하다는 점으로 인해, 콘 텐츠 이용의 범주 또한 관점에 따라 다양하게 설정됨

- 국제 공공기관인 UN, $\mathrm{OECD}$, 또는 IMF 등이나, 콘텐츠 이용 통계를 생산하는 정부 부처, 민간기업의 필요나 목적에 따라 콘텐츠 이용 범주를 다양하게 설정 하고 있음

[그림 2-3] 해외 주요 국가의 콘텐츠산업(문화산업) 특수분류체계 범주

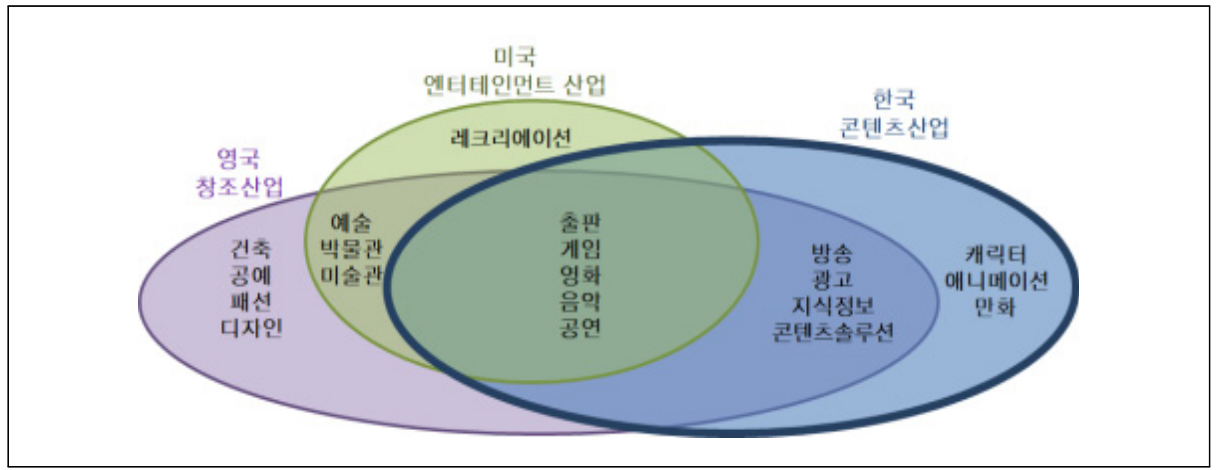

자료: Department for Culture Media \& Sport(2014), Creative Industries Economic Estimates, Office National Statistics.

Executive Office of the President of the United States(2017), North American Industry Classfication System. 통계청(2020), 콘텐츠산업 특수분류체계 활용,

김소연 외(2020), 콘텐츠산업 분야 통계 체계구축 및 발전방안 연구에서 인용

- 해외 주요 국가들 중, 콘텐츠 이용 범주를 설정한 사례를 구체적으로 주요 조사통 계 자료를 통해 확인한 결과, 영국과 유럽, 그리고 미국에서는 콘텐츠 이용을 '사 교'나 '여가', '엔터테인먼트' 또는 '대중매체' 활동 등의 다양한 범주의 하위 범주 로 측정하고 있는 것으로 나타남

- 분석에는 영국 시간사용조사(UK Time Diary Study), 유럽 단위에서는 유럽통 합 생활시간조사(Harmonised European Time Use Survey), 미국 생활시간 조사(American Time Use Study)와 같이 국제 비교 분석시 활용도가 높은 자 료를 활용하였음 


\section{나. 국내 콘텐츠 이용 범주}

- 우리나라에서도 콘텐츠 이용 범주는 정부 부처나 민간기업, 학계 등 작성 주체에 따라 다양하게 설정되고 있음. 공공보다 민간에서는 특정 서비스로 한정된 범주를 설정하는 경향이 있음

- '콘텐츠산업 특수분류체계'는 통계법상 효율적인 통계 작성을 목적으로 구축되어, 콘텐츠 이용 범주를 비교적 명확하게 설정하고 있음

- 특수분류는 통계 자료 작성시 반드시 적용해야 할 강제성은 없지만, 공공분야에 서 생산되는 콘텐츠 관련 통계 자료가 절대적으로 부족한 상황에서 사업체, 종 사자, 이용자, 또는 품목 등 다양한 층위에서 일관성있는 기준을 적용하여 자료 를 효율적으로 생산하는데 있어서는 활용 가치가 높음

- 국가승인통계 자료들 가운데, 콘텐츠 이용 범주가 확인되는 시례를 구체적으로 확 인한 결과, 콘텐츠산업 특수분류체계 12 개 범주를 모두 구분하는 자료는 없었음 - '애니메이션, '캐릭터', '지식정보', '콘텐츠솔루션', '광고' 5 개 분야는 콘텐츠 이용자를 대상으로 한 통계 작성이 상대적으로 부족하거나, 측정에 어려움이 있 어 별도의 자료로 생산되는 측면을 고려할 필요가 있음

- 또는 '영화', '방송' 등 특정 분야에 한정하여 하위 범주를 별도로 설정하는 경우 도 있음

- 분석에 활용한 자료는 콘텐츠산업 특수분류체계를 기준으로, 이용 범주를 확인 할 수 있는 국민문화예술활동조사, 국민여가활동조사, 생활시간조사, 한국미디 어패널조사, 인터넷이용실태조사, 방송매체이용행태조사, 청소년매체이용 및 유해환경 실태조사 7개 조사통계임

- 현재 국내에서 콘텐츠 이용 범주를 1 개 자료에서 가장 폭넓게 설정한 자료는 국민 여가활동조사로, 출판, 만화, 음악, 게임, 영화, 방송, 공연 7 개 분야를 측정하고 있으나, 세부적인 하위 행동분류의 구체성 정도에는 분야별로 차이가 있음 


\section{제2절 콘텐츠 이용자 대상 데이터 현황}

\section{1. 정형 데이터}

\section{가. 국가승인통계}

- 다음으로 본 절에서는 콘텐츠 이용자를 대상으로 생산되는 국내의 주요 데이터 현 황을 파악하고자 함. 콘텐츠 이용자 데이터는 크게 정형 데이터와 비정형 데이터로 구분할 수 있음

- 정형 데이터의 가장 대표적인 형태가 조사통계 자료임. 콘텐츠 이용자 대상의 조사 통계 자료는 공공과 민간 영역에서 다양하게 생산되고 있음

- 이 가운데 국가승인 조사통계 자료는 통계청을 통해 표본설계에 있어 비교적 엄격 한 작성 심사 과정을 거치고, 표본추출시 필수적으로 확률표집 방법을 적용하기 때문에, 가장 대표성을 갖추고 있다는 강점이 있음

- 확률표집의 기본적인 전제는 현실(전체 모집단)을 유용하게 기술하기 위해, 필 수적으로 모집단과 동일한 표본 구조를 갖춰야 한다는 것임. 이를 두고, '표본이 모집단에 대한 대표성을 갖추었다'고 표현함. 물론 현실적으로 모든 표본이 모 집단을 모든 점에서 완벽하게 대표하기 어렵다는 현실적인 이유로 모집단에 대 한 유사 명부를 활용함

- 확률표집한 자료는 확률이론1)에 근거하여, 표본이 모집단을 얼마나 잘 대표하 는지를 추정할 수 있게 됨. 현실적으로 대표성을 갖춘 표본을 구성하는데 필요

1) 확률이론은 각 조사의 성격에 따라 대표성이 있는 표본을 산출하는 표집기법을 고안하고, 표집결과를 통계 적으로 분석하기 적합하게 하는 근간임. 구체적으로 우리는 확률이론에 기반하여, 모집단의 변수에 대한 요약적인 기술인 모수(parameter)를 추정할 수 있게 됨. 즉, 모집단의 모수를 추정하기 위해서 표본을 사 용하는 것임. 확률표집은 모집단의 모수를 특정 범위 안에서 정확하게 추정할 수 있게 해주기 때문에 비확 률표집보다 선호됨 
한 예산이나 시간, 그 외의 자원 등 조건이 허락될 경우에는 통계청 인구총조사 (인구주택총조사, 등록센서스) 자료를 표집틀로 활용할 수 있음

- 현재 콘텐츠 이용자를 대상으로 한 국가승인통계들은 모두 다단계 층화 집락 확률 표집 방법을 채택하고 있는 것으로 확인되며, 대부분 조사통계 원자료와 기초통계 보고서를 일반에 개방하고 있음. 참고로 다단계 층화 집락 확률표집 과정은 다음과 같음

- 첫째, 표집틀을 사용해서 전국 조사구를 추출, 둘째, 조사구에서 조사가구를 추 출, 셋째, 조사가구에서 조사원을 추출함

- 최종적으로 성별, 연령별, 지역별 모집단의 특성을 고려하여, 대표성을 갖춘 표 본을 생산하는 과정을 거침. 이 때 모집단의 집단별 비율을 그대로 적용하기도 하고, 또는 제곱근 값에 비례하는 비율을 적용하기도 함

- 국가승인통계 자료들 간 표집 단계에서 발생하는 차이점은 조사목적에 따라 목 표모집단과 표집틀이 상이하다는 점에서부터 시작한다고 볼 수 있음

\section{나. 주요 실태조사}

- 공공 영역에서는 주요 실태조사를 포함한 다양한 종류의 비승인통계 자료들도 생 산함. 이 자료들은 각 기관이나 조사회사 등이 자체적으로 보유한 응답자 명부를 표집틀로 삼아, 이 단계에서 국가승인통계 자료들이 통계청이 제공하는 표집틀을 활용하여 대표성을 확보하는 방법과 차이가 발생할 수 있음

- 또한 비승인통계 자료들은 확률표집 방법을 반드시 적용해야할 의무는 없기 때문 에, 제한된 예산과 기간, 인력, 또는 특수한 조사목적을 달성하려는 이유 등에 따라 조사방법, 내용, 속도 등 많은 부분이 결정됨

- 현재 콘텐츠 이용자 층위에서 지속적으로 작성되어 온 주요 실태조사들은 출판, 만화, 음악, 게임, 애니메이션, 캐릭터 이용자 조사들인데, 세부적인 표본설계 방법 은 자료에 따라 차이가 있으며, 공식 보고서가 발표되고 있음 


\section{다. 민간 통계 자료}

- 그 외에도 국내 민간영역에서 콘텐츠 이용자들을 대상으로 생산하는 통계 자료들 은 매우 다양함. 그러나 민간 통계 자료는 작성주체인 기업 또는 사업체가 비공개 로 진행하는 경우도 많아, 공개 자료 외에 자료나 결과에 대한 접근성이 제한적임 - 대표적으로 시청률 조사나 미디어(기기, 채널, 프로그램), 인터넷, 모바일 이용 등, 주로 방송 및 통신 분야 조사가 많은 편임

- 나아가 콘텐츠와 관련된 특정 사이트, 어플리케이션, 채널이나 프로그램 등에 대한 이용자 분석 통계자료의 생산 또한 활발한 편임

\section{2. 비정형 데이터}

\section{가. 로그 데이터}

- 한편, 데이터 수집 및 분석 방법과 기술 발전에 따라, 콘텐츠 이용양상을 분석하기 위한 목적으로, 트래킹 소프트웨어를 활용하여 작성되는 로그데이터도 있음

- 로그데이터는 원천적으로 웹로그, 또는 모바일 트래픽 정보를 수집하는 반정형 데이터에 해당한다고 볼 수 있으나, 가공 단계를 거쳐 결과적으로는 통계 형식 의 정형 데이터로 활용됨

- 최초의 정보 수집 단계에서, 크롤링 정형화 소프트웨어를 활용하여 정형화된 자 료배열 구조로 수집한다면 정형 데이터로 볼 수 있으나, 대체로 최초 수집 데이 터의 최소 단위가 정형화하기 어려운 형태가 많아 대다수 비정형 데이터로 구분 하는 시례가 많음

- 로그 데이터를 최초 수집, 가공하는 방법과 조건에 따라, 정형 데이터 및 비정형 데이터로 구분할 수 있음

- 그러나 html 또는 SNS 텍스트, 이미지, 오디오 등의 다양한 로그 데이터들의 원천 형태는 비정형 데이터라고 볼 수 있음(Salganik, 2019) 
[그림 2-4] 로그 데이터: 정형·반정형·비정형 데이터 비교

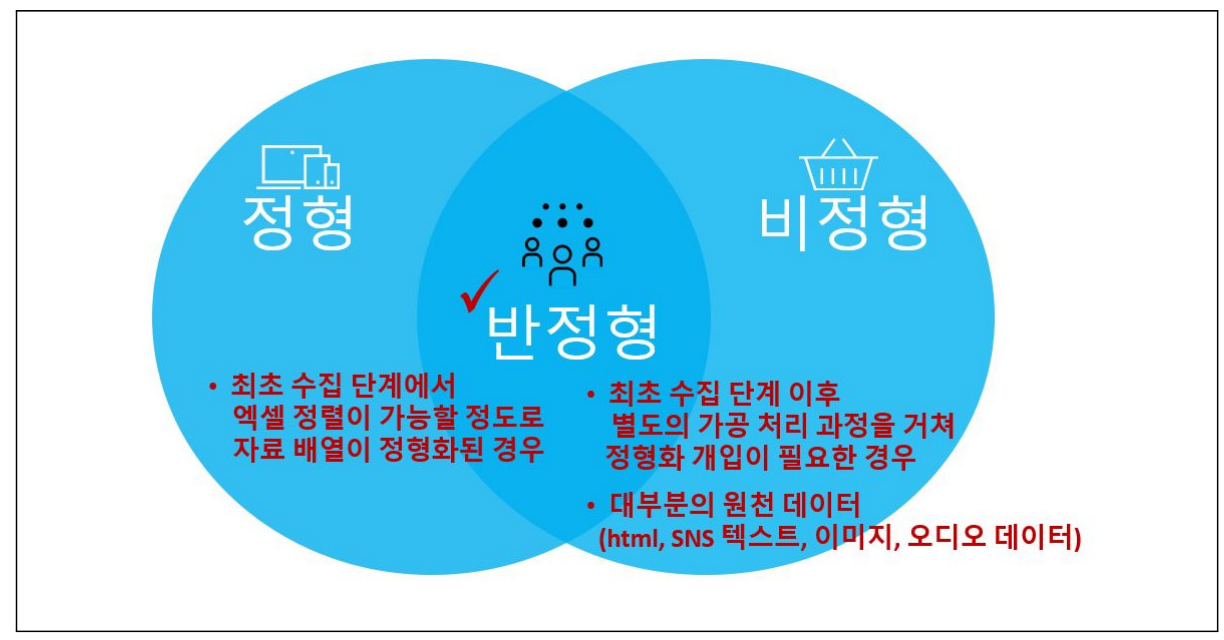

\section{나. 빅데이터}

- 일반적으로 '빅데이터'라 지칭되는 비정형 데이터는 기업 내·외부에 다양하게 존 재함. 콘텐츠 산업계에서는 이용자 층위에서 기업 내·외부에서 확보할 수 있는 비정형 자료의 활용도 활발한 편임

- 비정형 빅데이터는 콘텐츠 이용과 밀접한 관계에 있는 영상, 이미지, 음악, $\mathrm{SNS}$, 또는 블로그 메시지 데이터처럼, 일정한 구조나 형태로 정형화되어 있지 않더라도 이용자 또는 품목으로서 콘텐츠의 패턴을 파악할 수 있는 자료로, 활 용도가 빠르게 증가해왔음

- 콘텐츠 이용자에 관련된 비정형 데이터의 기초자료는 주로 특정한 브랜드나, 특정 한 서비스에 이용자가 제공한 정보들(데이터 흔적, Data trace)임

- 만약 기업이 내부적으로 확보하고 있는 콘텐츠 이용자 비정형 데이터를 활용할 경우, 이용자들의 특정 상품이나 서비스 구매나 반응 양상을 면밀하게 분석할 수 있고, 데이터 규모가 크고 정보가 다양할수록 통계분석을 포함한 다차원 분 석이 가능해진다는 장점이 있음

- 그러나 콘텐츠 이용자 대상 비정형 데이터들을 활발하게 활용할 수 있는 역량은 기업 또는 사업체에 따라 차이가 있음 
- 관련 정보를 활용할 수 있는 역량이나 접근성 정도에 차이가 있기 때문임. 일반 적으로 사업 규모가 큰 기업이나 데이터의 활용 가치를 중시하는 콘텐츠 관련 스타트업, 또는 광고주의 요청에 의해 필요한 경우 등 비공개 분석에 활용하는 사례가 많음

- 예를 들어, 넷플릭스나 유튜브와 같은 글로벌 콘텐츠 기업은 전세계 이용자의 기업 내부 로그 데이터를 활용하여 이용자들의 행동패턴을 파악할 수 있음. 이 용자들이 서비스를 이용하면서 남긴 데이터 흔적을 활용하는 것임

- 구체적으로 특정 고객이 검색한 기록, 서비스에 로그인한 시간, 서비스를 이용 하는 동안의 시간, 로그아웃에 이르는 시간에 이르는 각 이용시간대나 시간량, 영화, 드라마, 다큐멘터리 등 콘텐츠 이용의 카테고리 정보, 특정 콘텐츠를 재생 또는 정지한 시간, 하루 또는 월간, 연간 로그인 횟수, 기기, 구매나 결재 관련 신용 정보 등 다양한 정보를 활용하여 이용자들의 행동패턴을 분석할 수 있음

[그림 2-5] 넷플릭스 이용자 성향분석 목적 빅데이터 종류

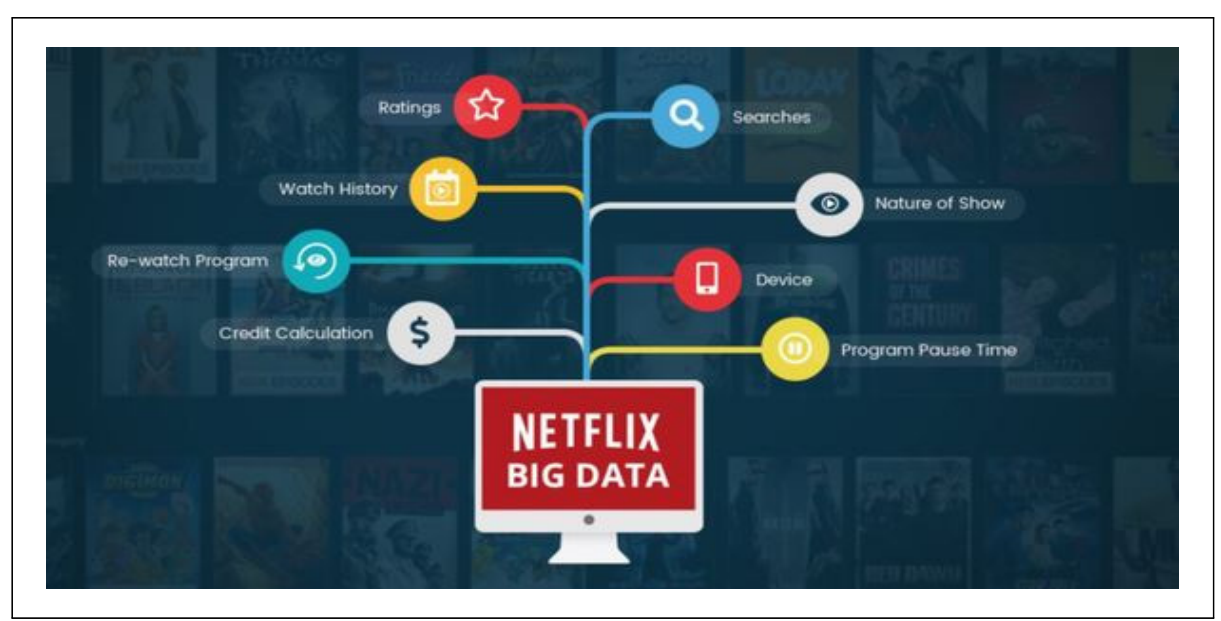

자료: Al 오디세이, 넷플릭스, Al를 활용한 고객분석으로 미디어 산업에서 경쟁 우위를 점함 (2021.03.24.일자 기사) http://mww.aio.world/news/articleView.html?idxno=690

- 이러한 비정형 데이터를 활용하여, 이용자의 특정 콘텐츠 서비스에 대한 이용양상 분석이 구체화되는 경향도 있음

- 기업이 내부적으로 보유하여 접근 가능성이 낮은 데이터와 주로 SNS나 커뮤니 티 여론 반응 행동 분석의 대상이 되는 데이터로 구분됨 
- 현재 공공영역에서는 콘텐츠 분야별로 이용자 빅데이터 자료를 구축하거나 활용하 고 있는 상황이 서로 다름

- 콘텐츠 이용자를 대상으로 생성되는 빅데이터의 활용 방법이 기획 방식에 따라 매우 다양할 수 있음을 시사함

- 일례로 출판 분야의 경우, 국립중앙도서관이 도서관을 이용하는 이용자들의 이 용 만족도나 의견 데이터를 체계적으로 수집하여 챗봇 개발이나 도서관 프로그 램, 정책 수립에 활용하고자 한 사례가 있음

- 방송 분야의 경우, 국내·외 방송 콘텐츠 및 채널 이용자 등의 반응을 파악하기 위한 연관어 분석시, 빅데이터를 활용하고 있음

〈표 2-2〉 콘텐츠 이용자 대상 빅데이터 활용 및 관련사업 추진 현황

\begin{tabular}{c|l|l|l}
\hline 구분 & \multicolumn{1}{|c|}{ 주요 대상 } & \multicolumn{1}{c|}{ 활용 현황 및 추진 목적 } & \multicolumn{1}{c}{ 주관 } \\
\hline 출판 & 도서관 이용자 & 도서관 이용 및 만족도 향상 의견 축적 & 국립중앙도서관 \\
\hline 만화·웹툰 & 만화·웹툰 이용자 & 추천 엔진 개발 추진 & 중소기업청 \\
\hline 영화 & 영화 이용자 & 예매율, 좌석점유율 정보 제공 & 영화진흥위원회 \\
\hline 방송 & 방송 콘텐츠 이용자 & 인터넷 반응, 종합 반응, 해외 반응 파악 & 방송통신위원회 \\
\hline 음악 & 음악 이용자·사업자 병합 데이터 & 음원 사용 및 거래 정보 & 한국저작권위원회 \\
\hline
\end{tabular}

자료: 국립중앙도서관(2018), 도서관 빅데이터 기반 정보서비스 시스템 구축 정보화 전략계획 수립 중소기업청(2017), 사용자 빅데이터를 이용한 만화·웹툰 개인화 추천 엔진 개발 영화진흥위원회(2021), 영화관 입장권 통합전산망 검색결과 방송통신위원회(2021), 방송콘텐츠 가치정보 분석시스템 검색결과 한국저작권위원회(2021), 권리자찾기 정보시스템 디지털저작권거래소 검색결과 


\section{제3절 시사점}

\section{1. 콘텐츠 이용자에 대한 체계적인 이해의 필요성}

- 콘텐츠 이용자는 산업계나 사업체에 비해, 그동안 조사, 연구, 분석 대상으로서 상 대적으로 취약했으나, 4차 산업혁명 디지털 경제 구조에서 이용자의 영향력이 부 상함에 따라 이들을 심층적으로 이해해야할 필요성이 높아짐

- 디지털 경제 구조에서 개인 또는 개인성이 산업계에 미치는 영향력이 커졌기 때문인데, 콘텐츠 산업에서도 같은 맥락에서 콘텐츠 이용자에 대한 섬세한 이해

를 위해, 콘텐츠 이용자를 대상으로 한 체계적인 데이터가 요구됨

- 콘텐츠 이용의 주체로서 '콘텐츠 이용자'는 원칙적으로 기업, 가계(가구, 가정), 정 부, 비영리 기관, 개인 등이 다양하게 해당될 수 있으나, 본 연구에서는 콘텐츠를 직접 이용하는 사람, 즉 '이용자 개인'을 대상으로 함

- '콘텐츠 이용'에 대한 정의는 일정하게 확립된 바는 없으나, 국내 콘텐츠 및 콘텐츠 산업에 대한 정의에 근거하면, 미디어 기기나 플랫폼 서비스를 통해 콘텐츠 서비스 나 상품을 이용하는 한 개인의 이용행태로 이해할 수 있음

- 한편으로는 여가(휴식, 엔터테인먼트, 레크리에이션)나 사회문화적 활동(사회생 활, 사교생활)의 하위범주로 설명되어 옴

- 또다른 면에서는 콘텐츠의 이용이 미디어 기기나 플랫폼 서비스와 매우 밀접한 관계에서 발생하는 행위라는 특성으로 인해, 미디어 기기나 플랫폼 서비스 등의

발전사에 따라 미디어 이용과 특별한 구분없이 다뤄져 온 측면도 있음

- 콘텐츠 이용행위는 '온라인' 공간에서만 발생하는 것으로 국한되지 않고, '오프라 인' 공간 기반의 행위로 확장되는 융·복합적인 성격을 가짐

- 이러한 콘텐츠 이용자를 체계적으로 이해하기 위해서는 일관성 있는 데이터 체계 
를 통해, 콘텐츠 이용에 직결된 소비 또는 소득 수준과 같은 경제적 요인들 뿐만 아니라, 실제 콘텐츠 이용과 영향을 주고 받는 사회적 요인들, 콘텐츠 이용이라는 행위를 통해 획득하는 효용감 또는 선택에 영향력을 미치는 심리적 요인, 관련 정 책 등에 이르기까지, 콘텐츠 이용자와 유기적인 관계를 형성하고 있는 다양한 정보 를 체계적으로 생산하고 활용해야 함

[그림 2-6] 콘텐츠 이용자 정보 가치 부상

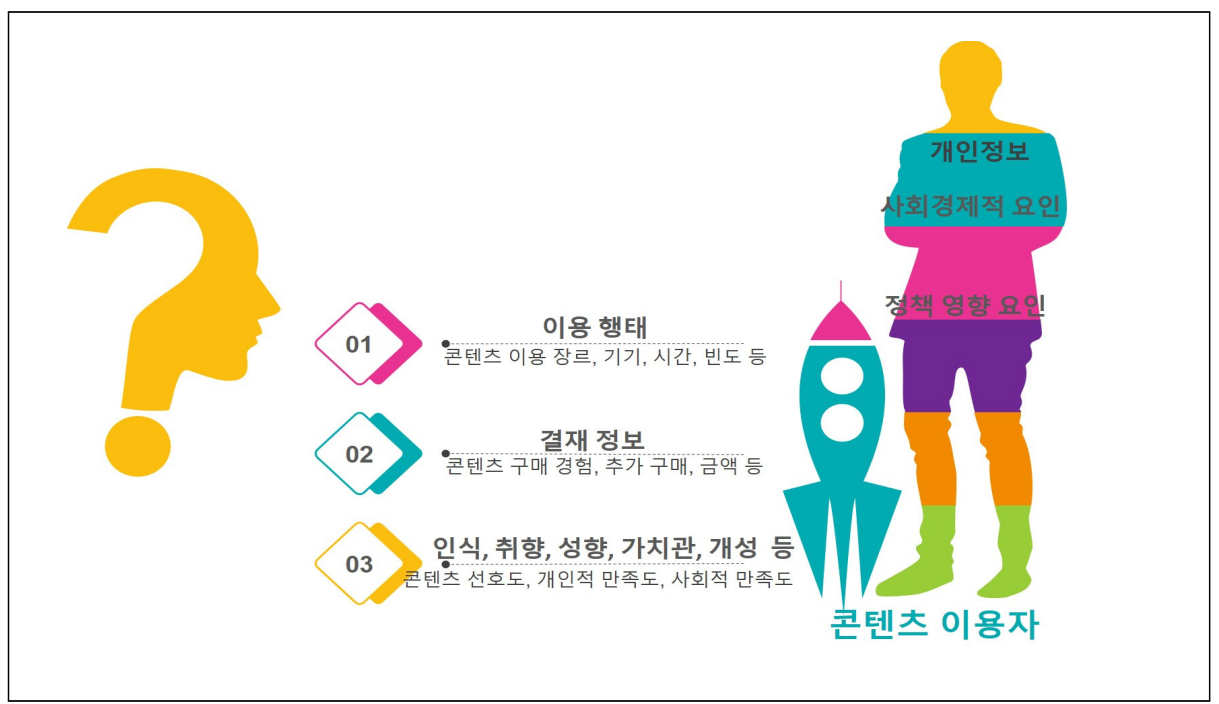

\section{2. 콘텐츠 이용에 대한 정의와 범주의 다양성}

- 콘텐츠 이용에 대한 정의와 범주는 국가별, 지역별, 자료 작성기관별로 매우 다양 함. 본 장에서는 콘텐츠 이용행태를 확인할 수 있는 국내·외 주요 자료를 구체적으 로 검토하여, 정의와 범주가 서로 어떻게 다른지 확인하였음

- 국제적으로 활용도가 높은 해외 주요 국가들의 조사통계 자료로 콘텐츠 이용 범주 를 검토한 결과, 우리나라가 대체로 '콘텐츠산업 특수분류체계'를 기준으로 콘텐츠 장르를 범주화한 것과 차이가 있음을 확인함

- 이는 콘텐츠 산업을 이해하는 국가적, 사회적 관점이 서로 다름으로 인한 결과 라 볼 수 있음 
- 특히 영국이나 유럽, 미국에서는 콘텐츠 범주 내에 만화, 애니메이션, 캐릭터를 독립적인 장르로 구분하지 않았음

〈표 2-3〉 해외 주요 조사의 콘텐츠 이용 범주

\begin{tabular}{|c|c|c|c|c|}
\hline 구분 & $\begin{array}{l}\text { 콘텐츠 } \\
\text { 분류 } \\
\text { (장르) }\end{array}$ & $\begin{array}{c}\text { 영국 } \\
\text { 시간사용조사 } \\
\text { (UK Time Diary Study) }\end{array}$ & $\begin{array}{c}\text { 유럽 } \\
\text { 통합생활시간조사 } \\
\text { (Harmonised European } \\
\text { Time Use Survey) }\end{array}$ & $\begin{array}{c}\text { 미국 } \\
\text { 생활시간조사 } \\
\text { (American Time } \\
\text { Use Study) }\end{array}$ \\
\hline 1 & 출판 & 0 & 0 & 0 \\
\hline 2 & 만화 & - & - & - \\
\hline 3 & 음악 & 0 & 0 & 0 \\
\hline 4 & 게임 & 0 & 0 & 0 \\
\hline 5 & 영화 & 0 & 0 & $\bullet$ \\
\hline 6 & 애니메이션 & - & - & - \\
\hline 7 & 방송 & 0 & 0 & - \\
\hline 8 & 광고 & - & - & - \\
\hline 9 & 캐릭터 & - & - & - \\
\hline 10 & 지식정보 & - & - & - \\
\hline 11 & 콘텐츠솔루션 & - & - & - \\
\hline 12 & 공연 & D & 0 & D \\
\hline 13 & 건축 & (1) & 0 & D \\
\hline 14 & 공예 & (1) & 0 & D \\
\hline 15 & 패션 & (1) & 0 & D \\
\hline 16 & 디자인 & (1) & 0 & D \\
\hline 17 & 예술 & (1) & 0 & 0 \\
\hline 18 & 박물관-미술관 & (1) & 0 & 0 \\
\hline 19 & 레크리에이션 & (1) & 0 & 0 \\
\hline
\end{tabular}

자료: Department for Culture Media \& Sport(2014), Creative Industries Economic Estimates, Office National Statistics.

Executive Office of the President of the United States(2017), North American Industry Classfication System.

통계청(2020), 콘텐츠산업 특수분류체계

Center for time use research(2015), UK Time Diary Study 2014-2015.

U.S. Bureau of Labor Statistics(2011), American Time Use Survey Activity Lexicon 2011.

자료 재구성

- 우리나라는 대표성을 갖춘 국가승인 조사통계 자료를 통해 콘텐츠 이용 범주를 검 토하였음. 그 결과 '콘텐츠산업 특수분류체계'를 기준으로 하더라도 콘텐츠 이용양 상을 종합적으로 측정하고 있는 자료는 없음을 확인함 
- 국민여가활동조사가 콘텐츠산업 특수분류체계 12 개 장르 가운데, 가장 많은 7 개 장르의 행동분류를 범주화하였지만, 이 또한 이용자의 실질적인 콘텐츠 이용 행태를 측정하는데 있어서는 부족한 상태였음

- 우리나라도 해외의 경우와 마찬가지로, 광고, 지식정보, 콘텐츠솔루션, 애니메 이션, 캐릭터 분야를 별도로 구분하여 측정하지 않는 경향이 확인되었으나, 조 사목적과 필요에 따라 별도 조사에서 이용행태를 측정하고 있음을 참고할 필요 가 있음

〈표 2-4〉 우리나라 주요 조사의 콘텐츠 이용 범주

\begin{tabular}{|c|c|c|c|c|c|c|c|c|}
\hline 구분 & $\begin{array}{c}\text { 콘텐츠 } \\
\text { 분류 } \\
\text { (장르) }\end{array}$ & $\begin{array}{c}\text { 국민문화예술 } \\
\text { 활동조사 }\end{array}$ & $\begin{array}{l}\text { 국민여가 } \\
\text { 활동조사 }\end{array}$ & $\begin{array}{l}\text { 생활 } \\
\text { 시간 } \\
\text { 조사 }\end{array}$ & $\begin{array}{l}\text { 한국미디어 } \\
\text { 패널조사 }\end{array}$ & $\begin{array}{l}\text { 인터넷이용 } \\
\text { 실태조사 }\end{array}$ & $\begin{array}{l}\text { 방송매체 } \\
\text { 이용 } \\
\text { 행태조사 }\end{array}$ & $\begin{array}{c}\text { 청소년 } \\
\text { 매체이용 및 } \\
\text { 유해환경 } \\
\text { 실태조사 }\end{array}$ \\
\hline 1 & 출판 & - & 0 & 0 & 0 & 0 & - & 0 \\
\hline 2 & 만화 & - & 0 & - & - & - & - & 0 \\
\hline 3 & 음악 & - & 0 & 0 & 0 & 0 & - & - \\
\hline 4 & 게임 & - & 0 & 0 & 0 & 0 & - & - \\
\hline 5 & 영화 & O & 0 & O & 0 & 0 & - & - \\
\hline 6 & 애니메이션 & - & - & - & - & - & - & - \\
\hline 7 & 방송 & - & 0 & 0 & 0 & $\bullet$ & ○ & 0 \\
\hline 8 & 광고 & - & - & - & - & - & - & - \\
\hline 9 & 캐릭터 & - & - & - & - & - & - & - \\
\hline 10 & 지식정보 & - & - & - & - & - & - & - \\
\hline 11 & 콘텐츠솔루션 & - & - & - & - & - & - & - \\
\hline 12 & 공연 & (1) & $\bullet$ & D & - & - & - & - \\
\hline
\end{tabular}

참고: : 포함, $\mathbf{O}$ : 부분적 포함, -:-:측정하지않음

자료: 문화체육관광부(2020) 2020 국민문화예술활동조사,

문화체육관광부(2020) 2020 국민여가활동조사,

통계청(2019) 2019 생활시간조사,

정보통신정책연구원(2020) 2020 한국미디어패널조사,

과학기술정보통신부(2020) 2020 인터넷이용실태조사,

방송통신위원회(2020) 2020 방송매체이용행태조사,

여성가족부(2020) 2020 청소년 매체이용 및 유해환경 실태조사 재정리

- 국내 - 외 콘텐츠 이용자 대상 데이터들이 콘텐츠 이용 범주를 다양하게 설정한 것 은 자연스러운 일이나, 자료 간, 장르 간 비교 검토는 어려울 수 있음 


\section{3. 콘텐츠 이용자 데이터의 이질성}

- 본 장에서 콘텐츠 이용자 데이터 생산 현황을 살펴본 결과, 현재 콘텐츠 이용자를 대상으로 한 매우 다양한 형태의 데이터들이 생산되고 있음을 확인함

- 국내 공공영역에서는 조사통계 중심의 정형 데이터가 많이 생산되고 있음

- 국가승인 조사통계 자료는 다양한 조사통계 정형 데이터 가운데, 가장 대표성을 확보한 자료라는 강점을 확보하고 있음

- 그 외 공공, 민간 영역에서 다양한 형태의 조사통계 자료들이 생산됨

〈표 2-5〉 콘텐츠 이용자 대상 생산 데이터 현황

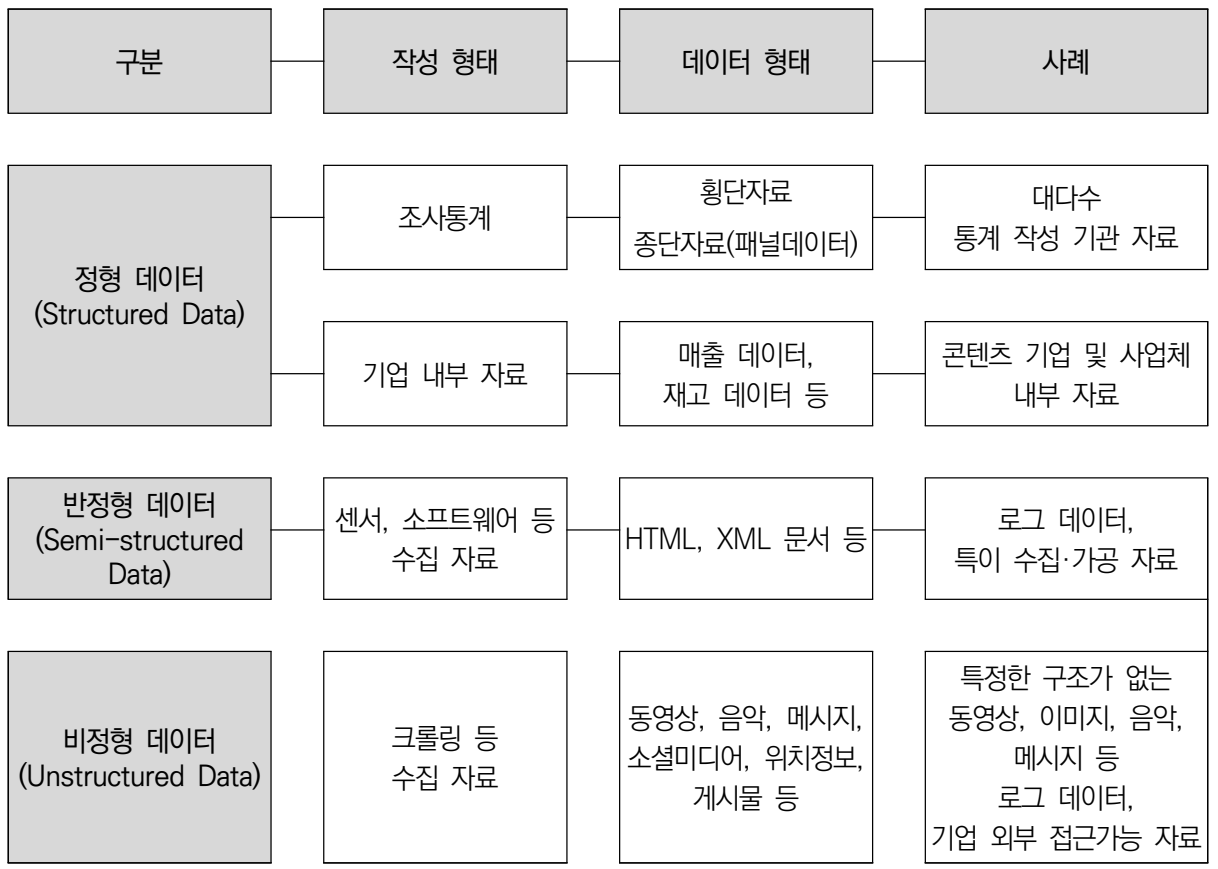

- 특이 시례로 민간 영역에서 콘텐츠 이용자를 대상으로 한 로그데이터 생산 현황을 확인함

- 로그데이터는 원천 정보 수집 방법이나 측정 규모에 따라, 비정형 데이터 또는 반정형 데이터로 볼 수 있으나, 해당 시례의 경우, 기초 조사설계, 가공 과정을 거쳐 통계 형태로 활용할 수 있는 정형 데이터로 통용되고 있었음 
- 로그데이터의 원천 데이터 형태를 기준으로 보면, 대부분 정형화되어 있지 않은 $\mathrm{html}, \mathrm{SNS}$ 텍스트, 이미지, 오디오 등의 다양한 형태의 비정형 데이터라 할 수 있음

[그림 2-7] PC 및 모바일 이용자 대상 로그데이터 수집 과정

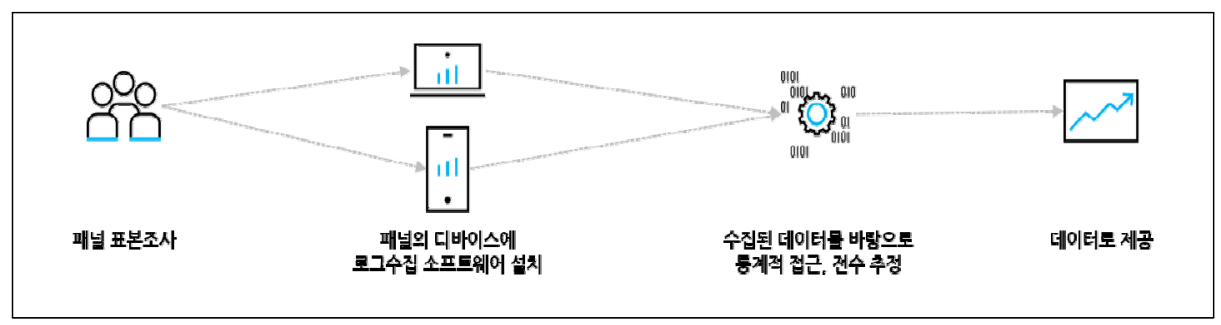

자료: 닐슨 내부자료 제공

- 그 외에도 주로 민간 영역에서는 콘텐츠 이용자의 데이터 흔적(Data trace)을 활 용한 비정형 빅데이터 분석도 활발한 편임

- 전통적인 통계 분석 방법은 표본(샘플)으로 모수(전체)를 추정하는 것이어서 표 본의 구성과 의미가 중요하나, 빅데이터 분석 방법은 샘플의 의미보다 확보된 데이터에 내재된 특정 패턴을 발견하는 것이 더 중요하다는 차이점이 있음. 따 라서 데이터의 형태나 규모, 분석 및 해석 방법 등에도 차이가 있을 수 있음 - 규모와 역량을 갖춘 콘텐츠 기업 또는 사업체들은 확보한 이용자 데이터를 활용 하여 이용자들의 콘텐츠 이용양상을 파악하며, 주요 관심은 신규 이용자, 서비 스에 대한 충성도가 높은 이용자, 또는 반대로 충성도가 낮은 이용자 등 최종적 으로는 특정 기업이나 사업의 서비스나 제품 구매에 어떤 요인이 도움이 되는지 를 규명하는 것이라 할 수 있음

- 따라서 이러한 데이터 활용 역량을 갖추지 못한 소규모 사업체들은 콘텐츠 이용 자에 대한 정보 격차를 초래할 가능성도 있음

- 한편, 이러한 이용자 빅데이터의 경우, 이용자가 제공하지 않은 정보, 즉 콘텐츠 이용자의 성, 연령, 또는 주거지역이나 국적과 같은 기초적인 사회경제적 정보 가 누락되어 이용자 식별에 불가능하거나, 최근 개인정보보호 관련 법과 인식이 변화하고 있는 점이 데이터 활용에 한계로 작용하는 경우가 있음 
- 콘텐츠 이용자를 대상으로 한 기초자료의 형태는 이처럼 다양할 수 있지만, 데이터 의 작성 형태가 매우 이질적이라는 점은 자료를 활용하는 이용자들에게 불편을 초 래할 수 있음

- 특히 콘텐츠 이용자를 대상으로 한 데이터를 지속적, 안정적으로 축적하여, 일관성 과 신뢰성을 갖춘 정보를 제공해야 할 필요성이 높음

- 현재와 같은 상황에서는 콘텐츠 이용자들이 실질적으로 어떤 콘텐츠 장르에 대 한 이용을 많이 하거나, 반대로 줄이는지, 나아가 증감에 영향을 미치는 요인이 무엇이며, 그 동태가 어떻게 변화하는지에 대해, 콘텐츠 관점에서의 이용양상을 체계적으로 파악할 수 있는 자료의 생산이 요구됨

- 이에 따라, 다음 장에서는 보다 구체적으로 콘텐츠 이용자를 대상으로 작성된 주요 조사통계 자료의 설계 방식과 내용을 검토하여, 콘텐츠 이용자 데이터 개발에 필요 한 내용을 도출할 수 있도록 함

- 현재 공공 영역에서 생산되고 있는 자료가 정형 조사통계 데이터이고, 비정형 데이터의 경우 기획 및 활용의 가능성이 무궁무진하며 콘텐츠 분야별로 활용의 가능성이 다양하므로, 분석은 현재 지속적으로 생산, 축적되고 있는 조사통계 자료를 중심으로 진행함

- 민간 기업 내부 자료의 경우, 정보 공개가 매우 제한적이라는 현실을 고려할 수 밖에 없는 특수성이 있음 

콘텐츠 이용자 데이터 개발 기반연구

제3장

\section{콘텐츠 이용자 대상 \\ 주요 데이터 분석}





\section{제1절 주요 조사통계 표본설계 및 프레임}

\section{1. 국가승인통계}

\section{가. 국민문화예술활동조사(구, 문화향수실태조사)}

1) 조사 특성

- 국민문화예술활동조사는 국민의 문화 활동에 대한 인식 수준이 높아짐에 따라, 관 련 실태 파악을 통해 문화 진흥을 도모할 것을 목적으로 한 조사임 - 이에 따라 조사대상은 전국 만 15 세 이상 인구로 폭넓게 설정되었음

- 조사의 특이점은 국민문화예술활동조사의 핵심 개념인 '문화예술활동'을 주로 오 프라인 공간에서의 관람이 가능한 문학, 미술, 서양음악, 전통예술, 연극, 뮤지컬, 무용, 영화, 대중음악.연예 9가지로 범주화하였다는 점임

- '복합문화예술'은 이 가운데, 2개 이상이 합쳐진 복합형태의 행사로, 예를 들어 미술전시와 클래식음악회가 함께 진행되거나, 영화관람과 가요콘서트가 함께 진행되는 형태임

〈표 3-1〉 국민문화예술활동조사 조사표

\begin{tabular}{|c|c|c|c|c|c|c|}
\hline 작성주체 & 조사대상 & 주기 & 연혁 & 표본규모 & 표본추출 & 자료배열 \\
\hline $\begin{array}{l}\text { 문화체육 } \\
\text { 관광부 }\end{array}$ & 전국 만 15세 이상 & 1년 & $\begin{array}{c}\text { 1988년 } \\
\text { 현재 }\end{array}$ & $\begin{array}{l}10,000 \text { 가구 } \\
(10,099 \text { 명) }\end{array}$ & $\begin{array}{l}\text { 다단계 층화 } \\
\text { 집락 확률표집 }\end{array}$ & 횡단 \\
\hline
\end{tabular}

자료: 문화체육관광부(2020), 2020 국민문화예술활동조사

2) 프레임

- 국민문화예술활동조사에서 콘텐츠 이용과 관련된 내용은 '매체이용 예술행사 관람 실태'에 일부 포함되어 있으나, ‘문화예술행사'의 관람 경로를 확인하기 위함임 
- 매체는 텔레비전(지상파, 케이블, 라디오), PC 및 노트북, 스마트기기(스마트폰, 태블릿PC), 비디오/DVD/CD플레이어 4가지 종류로 구분하였음. 최근에는 온 라인 동영상 제공 서비스(OTT)를 통한 예술행사 관람 경험을 확인할 수 있도록 별도 구성함

- 문화예술 관련 지출 조사항목을 통해서는 구입 및 대여(도서, 작품, 음원, 영상 등), 직접 관람, 기타(강습비, 학원비 등) 3 가지 항목 중 가장 많이 지출하는 항 목, 향후 지출을 늘리고 싶은 항목을 조사하고 있음

- 이처럼 국민문화예술활동조사는 '문화예술 관람 및 참여 실태'를 중심으로, 주로 오프라인 활동 정보를 수집함

- 문화예술활동 범주에 기반한 교육이나 공간 이용의 실태, 관련 자원봉사나 동호 회 참여 등의 문화관련활동, 역사문화 유적지나 축제 관람의 실태 파악도 이러 한 관점의 연장선상에 있음

- 따라서 콘텐츠 이용은 영화, 대중음악.연예 등의 관람 활동과 매체를 확인할 수 있는 정도여서, 측정 단계에 세부 내용이 충분히 반영되지 못한 한계가 있음

- 정책적 관심이 반영된 결과로 볼 수 있는 부분은 '근로시간 단축제' 정책에 따른 문화예술 활동과 인식 변화 정보임

〈표 3-2〉 국민문화예술활동조사(구, 문화향수실태조사) 프레임

\begin{tabular}{c|l}
\hline 주요 구분 & \multicolumn{1}{c}{ 세부 내용 } \\
\hline 사회인구학적 특성 & 성, 연령, 학력, 지역, 지난 1주간 경제활동 상태, 직업, 종사상 지위, 소득 등 \\
\hline 문화예술 관람 및 참여 실태 & 예술행사, 복합문화예술, 직접 또는 매체이용 관람 및 참여 실태 및 지출 \\
\hline 문화예술교육 경험 및 실태 & 유아기, 청소년기, 1년이내 학교교육 내외 강좌, 강습 경험, 시설, 교육방법 등 \\
\hline 문화예술활동 공간 이용 실태 & 공간이용 실태 및 방문 의향 \\
\hline 문화관련 활동 실태 & 자원봉사 및 동호회 경험 \\
\hline 역사문화유적지 및 축제 & 역사문화유적지 방문·축제 관람 경험 및 의향 \\
\hline 정책 이슈 & 근로시간 단축제 관련 \\
\hline
\end{tabular}

자료: 문화체육관광부(2020), 2020 국민문화예술활동조사 


\section{나. 국민여가활동조사}

1) 조사 특성

- 국민여가활동조사는 국민의 여가생활 실태와 여가환경 등에 대한 정보를 종합적으 로 파악하여 여가 정책 수립의 기초 자료로 활용할 것을 목적으로 하는 조사임 - 이에 따라 조사대상은 전국 만 15 세 이상 인구로 폭넓게 설정되었음

- 콘텐츠 이용을 세밀하게 구분하여 측정하지는 않으나, 여가활동의 일부로 포함하 고 있다는 특성이 있음

〈표 3-3〉 국민여가활동조사 조사표

\begin{tabular}{|c|c|c|c|c|c|c|}
\hline 작성주체 & 조사대상 & 주기 & 연혁 & 표본규모 & 표본추출 & 자료배열 \\
\hline $\begin{array}{l}\text { 문화체육 } \\
\text { 관광부 }\end{array}$ & 전국 만 15 세 이상 & 1년 & $\begin{array}{l}\text { 2006년 } \\
\text { - 현재 }\end{array}$ & $\begin{array}{l}10,000 \text { 가구 } \\
(10,088 \text { 명) }\end{array}$ & $\begin{array}{l}\text { 다단계 층화 } \\
\text { 집락 확률표집 }\end{array}$ & 횡단 \\
\hline
\end{tabular}

자료: 문화체육관광부(2020), 2020 국민여가활동조사

2) 프레임

- 국민여가활동조사에서 정의하는 여가활동은 크게 문화예술관람활동, 문화예술참 여활동, 스포츠관람활동, 스포츠참여활동, 관광활동, 취미오락활동, 휴식활동, 사 회 및 기타 활동 8 가지로, 여가활동을 세밀하게 구분하고자 한 특징이 있음

- 콘텐츠 이용과 관련된 내용은 주로 '취미오락활동’ 및 ‘휴식활동', '사회 및 기타활 동’에 해당함

- 취미오락활동에는 홈페이지·블로그 관리, 인터넷 검색· 1 인 미디어 제작·

$\mathrm{SNS}$, 게임(온라인 · 모바일 · 콘솔게임 등), 독서(웹소설 포함), 만화보기(웹툰포 함)라는 이용 활동이 포함됨

- 휴식활동에는 TV시청(IPTV포함), 모바일 콘텐츠, 동영상, $\mathrm{VOD}$ 시청, 라디오 · 팟캐스트 청취, 음악 감상, 신문·잡지보기가 포함됨

- 사회 및 기타 활동 중에는 통화하기 · 문자보내기(모바일 메신저 메시지 포함)라 는 미디어 이용 활동이 포함되어 있음

- 국민여가활동조사는 이처럼 노동시간, 학습시간(교육시간), 개인유지시간(수면, 식 
사, 이동 등) 등을 제외한 '여가시간'과 '여가공간' '여가 인식 및 만족도'를 중심 으로, '여가활동 실태’를 파악하는 구조로 설계됨

- 이에 따라 여가활동과 직결된 정책의 효과와 일반적인 인식의 변화를 지속적으로 함께 검토할 수 있도록, '일과 여가의 균형', '여가에 대한 인식 및 만족도', '행복 수준 등의 정보를 확인할 수 있도록 구성됨

〈표 3-4〉 국민여가활동조사 프레임

\begin{tabular}{|c|c|}
\hline 주요 구분 & 세부 내용 \\
\hline 사회인구학적 특성 & 성, 연령, 지역, 지난 1주간 경제활동 상태, 직종, 종사상 지위, 소득 등 \\
\hline \multirow{3}{*}{ 여가활동 참여 실태 } & 여가활동 유형, 동반자, 빈도, 소요시간, 만족도, 목적 등 \\
\hline & 지출 비용 \\
\hline & 여가활동 다양성(동호회, 자원봉사, 스마트기기를 활용한 여가활동) \\
\hline 여가활동 시간 & 평일·휴일 여가활동 및 만족도, 여가시간 충분정도, 활용정도, 희망시간, 휴가-연휴 활용 등 \\
\hline 여가활동 공간 & 가장 많이 이용하는 여가공간, 공공문화여가시설·여가산업에 대한 평가(만족도) \\
\hline $\begin{array}{c}\text { 여가 및 관련 정책 } \\
\text { 인식과 만족도 }\end{array}$ & 일과 여가의 균형, 정책 중요도 및 만족도 평가, 여가에 대한 인식 및 만족도, 행복수준 등 \\
\hline
\end{tabular}

자료: 문화체육관광부(2020), 2020 국민여가활동조사

\section{다. 생활시간조사}

\section{1) 조사 특성}

- 통계청 생활시간조사는 국민들의 전반적인 생활 시간 사용 양상을 파악하여, 생활 방식을 파악하는 것을 목적으로 하는 조사임

- 이를 위해 조사대상은 전국 만 10세 이상 인구로 폭넓게 설정됨

- 통계청 생활시간조사는 표본으로 선정된 가구를 대상으로, 대표 가구원(가구조 사)과 일반 가구원(개인조사) 정보를 구분하여 수집하는 방대한 조사임

- 생활시간조사는 응답자 1 인의 2 일간 모든 일상 활동을 24 시간, 10 분 간격으로 작 성하는 시간일지(time dairy) 구조를 갖추고 있음

- 이 때문에 자료배열 구조는 개인식별코드(ID) 1 개 당, 2 일간의 시간 사용 정보 가 2개의 행(row)에 연속적으로 기록되는 형태임. 실증 분석 단계에서, 이 점에 유의하지 않고 처리할 경우, 분석결과에 편향(bias)이 발생할 수 있음 
〈표 3-5〉 생활시간조사 조사표

\begin{tabular}{|c|c|c|c|c|c|c|}
\hline 작성주체 & 조사대상 & 주기 & 연혁 & 표본규모 & 표본추출 & 자료배열 \\
\hline 통계청 & 전국 만 10 세 이상 & 5년 & $\begin{array}{l}\text { 1999년 } \\
\text { - 현재 }\end{array}$ & $\begin{array}{c}12,435 \text { 가구 } \\
(26,091 \text { 명 })\end{array}$ & $\begin{array}{l}\text { 다단계 층화 } \\
\text { 집락 확률표집 }\end{array}$ & 횡단 \\
\hline
\end{tabular}

자료: 통계청(2019), 2019 생활시간조사

2) 프레임

- 생활시간조사의 주요 조사로서 개인을 대상으로 한 설문은 생활시간 사용 내용을 세밀하게 파악하도록 설계됨

- 이때, 시간 사용 내용은 '개인유지시간, 일하는 시간, 학습시간, 가정관리시간, 돌봄시간, 자원봉사 및 무급 활동시간, 교제 및 참여활동, 문화 및 여가활동, 기 타' 시간으로 구분됨

- 시간일지는 행동분류를 기준으로 주로 한 행동, 동시에 한 행동, 장소 또는 이동 수단, 함께한 사람, 작성한 날의 상황의 정보를 함께 수집함

- 최근 조사에서는 개인이 주로 한 행동과 동시에 한 행동을 기록할 때, ICT 기기 를 이용했는지의 여부를 함께 기록할 수 있도록 구성하였으며, 이때 ICT 기기 는 스마트폰·태블릿, PC·노트북 2가지로 구분함. 이를 통해, '인터넷으로 옷 쇼 핑', ‘스마트폰으로 게임하기'와 같이 ICT 기기와 행동 내용을 구체적으로 기입 하도록 안내하고 있음

- 콘텐츠 이용과 관련된 내용은 주로 '문화 및 여가활동' 시간 영역에 집중적으로 구성되어 있으나, 이는 응답자 개인이 행한 ‘행위’를 중심으로 구분이 가능한 정도 여서 콘텐츠 이용에 대한 상세한 구분은 불가능함

- 전체적으로 생활시간조사는 '생활시간'과 인과적 관계, 또는 역인과적 관계에 있을 수 있는 '사회경제적 요인'들과 '주관적 만족감'을 큰 틀로 설계됨

- 정책적 관심이 반영된 결과로 볼 수 있는 내용으로는 개인의 시간 부족감, 일과 후 피로감, 전반적인 삶에 대한 만족도, 여가시간에 대한 만족도, 가사분담에 대한 만족도, 남녀 역할 관념에 대한 동의정도 등의 정보임

- 생활시간조사는 의학, 사회과학 등 다양한 이종 분야의 연구에 활용됨으로서, 융복 
합 연구나 정책 개발이 가능한 프레임을 갖추고 있으나, 행동분류의 구체성 정도에 있어서는 분야별 한계도 확인됨

- 또한 미국, 유럽 등 국제 비교가 일부 가능하더라도, 작성주체에 따라 시간 사용 에 대한 세부적인 분류체계가 달라, 세밀한 비교는 불가능함. 특히 콘텐츠 이용 과 관련된 세부 분류는 국내 생활시간조사가 매우 구체적인 편이라 할 수 있음

〈표 3-6〉 생활시간조사 프레임

\begin{tabular}{|c|c|c|}
\hline \multicolumn{2}{|c|}{ 주요 구분 } & 세부 내용 \\
\hline \multicolumn{2}{|c|}{ 사회경제적 요인 } & 성, 연령, 학력, 경제활동(주로 하는 일, 부서 및 직책, 종사상 지위 등) 등 \\
\hline \multirow{8}{*}{ 시간 } & 개인유지시간 & 수면, 식사, 건강·위생·외모 관리 \\
\hline & 일 & 법인, 정부기관, 비영리단체·가계비법인기업·무급가족 종사, 구직·창업활동, 기타 \\
\hline & 학습 & 학교, 학교 외 활동 \\
\hline & 가정관리시간 & 음식, 의류, 청소, 주거, 차량, 반려동식물, 상품 및 서비스 구입 등 \\
\hline & 돌봄시간 & 만 10세 미만 아이·10세 이상 미성년자, 장기 돌봄 필요 성인, 독립적인 성인 돌보기 \\
\hline & $\begin{array}{l}\text { 자원봉사 } \\
\text { 및 무급연수 }\end{array}$ & $\begin{array}{l}\text { 비조비지직 기반 문화예술 활동 싲간 사회경제적 요인 직 기반, 조직 및 공동체 기반 } \\
\text { 자원봉사, 무급연수 및 관련 활동 }\end{array}$ \\
\hline & $\begin{array}{l}\text { 교제 및 참여 } \\
\text { 활동 }\end{array}$ & 대면·비대면 교제, 참여활동, 종교·의례 활동 \\
\hline & $\begin{array}{l}\text { 문화 및 } \\
\text { 여가활동 }\end{array}$ & $\begin{array}{l}\text { 영화, 공연, 전시 등 문화·관광활동, 미디어를 이용한 여가활동, 스포츠·레포츠 활동, } \\
\text { 게임 및 놀이, 휴식 관련 행동, 기타 여가활동 }\end{array}$ \\
\hline \multicolumn{2}{|c|}{ 주관적 만족감 } & $\begin{array}{l}\text { 시간부족감, 일과 후 피로감, 삶의 만족도, 여가시간 만족도, 가사분담 만족도, 남녀 역 } \\
\text { 할 관념에 대한 동의 정도 }\end{array}$ \\
\hline \multicolumn{2}{|r|}{ 기타 } & $\begin{array}{l}\text { 장소 또는 이동수단, 함께한 사람, ICT 기기(스마트폰, 태블릿, PC, 노트북) } \\
\text { 주행동, 동시행동 구분 }\end{array}$ \\
\hline
\end{tabular}

자료: 통계청(2019), 2019 생활시간조사

\section{라. 한국미디어패널조사}

1) 조사 특성

- 한국미디어패널조사는 국내 가구 및 개인의 미디어 이용현황을 파악하는 것을 목 적으로 하는 조사임 
〈표 3-7〉 한국미디어패널조사 조사표

\begin{tabular}{c|c|c|c|c|c|c}
\hline 작성주체 & 조사대상 & 주기 & 연혁 & 표본규모 & 표본추출 & 자료배열 \\
\hline 정보통신정책연구원 & 전국 만 6세 이상 & 1년 & $\begin{array}{c}\text { 2010년 } \\
- \text { 현재 }\end{array}$ & $\begin{array}{c}4,260 \text { 가구 } \\
(10,302 \text { 명 })\end{array}$ & $\begin{array}{c}\text { 다단계 층화 } \\
\text { 집락 확률표집 }\end{array}$ & 종단 \\
\hline
\end{tabular}

자료: 정보통신정책연구원(2020), 2020 한국미디어패널조사

- 콘텐츠 이용양상을 세밀하게 파악할 수 있는 장르별 구분은 취약하지만, 관련 내용 을 종단 정보로 파악할 수 있다는 특이성이 있음

〈표 3-8〉 한국미디어패널조사 구성

\begin{tabular}{|c|c|c|}
\hline \multicolumn{2}{|r|}{ 조사 구분 } & 세부 항목 \\
\hline \multirow[b]{2}{*}{ 공통조사 } & 가구용 & $\begin{array}{l}\text { 가구현황, 미디어 기기 보유 현황, 방송통신 서비스 가입 및 지출 현황, 미디어 } \\
\text { 이용지침 }\end{array}$ \\
\hline & 개인용 & $\begin{array}{l}\text { 개인 특성, 미디어 기기 보유 현황, 보유 기기간 연결 상태, 방송통신 서비스 } \\
\text { 가입 및 지출 현황, 미디어 다이어리, 미디어 활용현황, 미디어 } \\
\text { 이용확ㄱㅇㅇ(이용지침, 이용 능력 등), 전자상거래 및 통신판매 이용현황, } \\
\text { 특화내용: 가치관과 라이프스타일(2012년, 2016년), } \\
\text { 삶의 만족도(2013년, 2017년), } \\
\text { 건강행태(2014년), 식습관(2016년), 4차 산업혁명 전망 및 인식(2018년), } \\
\text { 소비자혁신성(2019년), 자아존중감 및 인지욕구(2015년, 2020년), } \\
\text { 비판적 미디어 이해능력(2020년) }\end{array}$ \\
\hline 추가조사 & 방송통신요금고지서 & $\begin{array}{l}\text { 유료방송(케이블, 스카이라이프, IPTV), 통신요금(휴대전화, 집전화, } \\
\text { 초고속인터넷요금 등) 등 }\end{array}$ \\
\hline
\end{tabular}

자료: 정보통신정책연구원(2020), 한국미디어패널조사 유저가이드

2) 프레임

가) 가구용

- 한국미디어패널 가구조사는 가구단위 공통 정보를 수집할 수 있도록 구성됨

- 가구원 등 가구현황, 미디어 기기 보유 및 이용현황, 방송통신 서비스 가입 및 지출 현황, 미디어 이용지침 관련 정보가 수집됨

〈표 3-9〉 한국미디어패널조사- 가구조사 프레임

\begin{tabular}{c|l}
\hline 주요 구분 & \multicolumn{1}{c}{ 세부 내용 } \\
\hline 사회경제적 특성 & 가구현황 \\
\hline 미디어 기기 보유 및 이용현황 & 텔레비전, 라디오, 게임기, 전화기, 드론, 컴퓨터, 노트북, 태블릿, 가용정 비디오. \\
녹화 기기, 촬영기기, 차량 미디어 기기, 기타 기기
\end{tabular}




\begin{tabular}{c|l}
\hline 주요 구분 & \multicolumn{1}{c}{ 세부 내용 } \\
\hline $\begin{array}{c}\text { 방송통신 서비스 가입 } \\
\text { 및 지출 현황 }\end{array}$ & $\begin{array}{l}\text { 통신, 방송, 이동통신 서비스 가입현황, 결합상품 지출현황, 단독상품 지출현황, } \\
\text { TV VOD 서비스 이용경험 및 지출 현황 }\end{array}$ \\
\hline 미디어 이용지침 관련 & 청소년·어린이 가정 내 TV, 인터넷, 게임 스마트기기 등 이용에 대한 제한 \\
\hline
\end{tabular}

자료: 정보통신정책연구원(2020), 한국미디어패널조사

나) 개인용

- 별도의 개인조사에서는 응답자 개인의 특성을 파악할 수 있는 사회경제적 요인 외 에도 뉴미디어 이용 현황, 미디어 이용행태, 미디어 다이어리, 전자상거래 등의 이 용 현황 등 미디어 이용을 세밀하게 파악할 수 있는 방대한 정보를 수집함

- 이 때 미디어 다이어리는 미디어 이용시간을 중심으로 한 시간일지(time dairy) 구조이나, 작성 방식에 있어서는 통계청 생활시간조사와 차이가 있음

- 개인층위에서 이러한 미디어 이용 정보와 함께, 연관 정책을 발굴하거나 점검할 수 있는 특화 정보도 함께 수집하는 구조임

- 연도별로 구성에 차이가 있으나, 구체적으로 미디어 이용자들의 가치관과 라이 프스타일(2012년, 2016년), 삶의 만족도(2013년, 2017년), 건강행태(2014

년), 식습관(2016년), 4차 산업혁명 전망 및 인식(2018년), 소비자혁신성(2019

년), 자아존중감 및 인지욕구(2015년, 2020년), 비판적 미디어 이해능력(2020

년) 등 지속적인 정책 개발 잠재력이 높은 내용임

〈표 3-10〉 한국미디어패널조사- 개인조사 프레임

\begin{tabular}{c|l}
\hline 주요 구분 & \multicolumn{1}{c}{ 세부 내용 } \\
\hline 사회경제적 요인 & 성별, 연령(출생연도), 최종학력, 결혼여부, 월평균 소득, 직업, 종사상 지위, 종교 \\
\hline 뉴미디어 이용현황 & 스마트기기 어플리케이션, OTT, 온라인 디지털 콘텐츠, SNS 이용 경험 \\
\hline $\begin{array}{c}\text { 휴대폰 및 스마트기기 } \\
\text { 보유 및 이용 현황 }\end{array}$ & 일반 휴대폰, 스마트폰, 태블릿, 웨어러블 기기 \\
\hline $\begin{array}{c}\text { 방송통신 서비스 가입 } \\
\text { 및 지출 현황 }\end{array}$ & $\begin{array}{l}\text { 휴대폰 기기 할부금, 어플리케이션 아이템 및 확장기능 구입 경험, 극장 영화, 음악회, } \\
\text { 크, 뮤지컬, 오페라 등 공연 관람 경험 및 지출금액 }\end{array}$ \\
\hline 미디어 이용행태 & $\begin{array}{l}\text { 스마트푼을 통한 음성·영상 통화 이용 경험, 신문 구독 경험, 즐겨보는 TV 프로그램, } \\
\text { PC·노트북·스마트기기 이용, 이메일·블로그·인터넷·클라우드 이용, 온라인 프라이버시 } \\
\text { 침해 우려 경험 }\end{array}$ \\
\hline $\begin{array}{c}\text { 전자상거래 및 } \\
\text { 통신판매 이용 현황 }\end{array}$ & $\begin{array}{l}\text { 전자상거래 및 통신판매 이용 경험, 인터넷 전용 은행·모바일 간편 송금 및 결제서비스 } \\
\text { 등 }\end{array}$ \\
\hline
\end{tabular}




\begin{tabular}{c|l}
\hline 주요 구분 & \multicolumn{1}{c}{ 세부 내용 } \\
\hline \multirow{2}{*}{ 미디어 다이어리 } & $\begin{array}{l}\text { 하루동안 특별한 일의 여부(시험, 경조사, 휴가·여행, 출장 등), 수면 시간, } \\
\text { 머무른 장소, 미디어 매체·행위(방송, 음악, 게임 등)·공간(영화관, 노래방, 공연장 등) }\end{array}$ \\
\hline
\end{tabular}

자료: 정보통신정책연구원(2020), 한국미디어패널조사

\section{마. 인터넷이용실태조사}

- 인터넷이용실태조사는 급속히 변화하는 인터넷 이용환경 및 행태 변화를 파악하 여, 정부 정책과 업계의 비즈니스 전략 수립, 학계의 연구 활동 등 다양한 영역에 서 활용할 수 있는 통계정보를 제공하는 것을 목적으로 하는 조사임

- 이에 따라 조사대상은 전국 25,000 가구 및 가구 내 상주하는 만 3 세 이상 가구 원으로 설정됨

- 인터넷이용실태조사는 ‘인터넷’이라는 매우 구체적이고 특정한 미디어 환경과 이 용현황 정보를 집중적으로 수집한다는 특이점이 있음

〈표 3-11〉 인터넷이용실태조사 조사표

\begin{tabular}{|c|c|c|c|c|c|c|}
\hline 작성주체 & 조사대상 & 주기 & 연혁 & 표본규모 & 표본추출 & 자료배열 \\
\hline 과학기술정보통신부 & 전국 만 3세 이상 & 1년 & $\begin{array}{l}\text { 1999년 } \\
\text { - 현재 }\end{array}$ & $\begin{array}{c}25,050 \text { 가구 } \\
(60,000 \text { 명 })\end{array}$ & $\begin{array}{l}\text { 다단계 층화 } \\
\text { 집락 확률표집 }\end{array}$ & 횡단 \\
\hline
\end{tabular}

자료: 과학기술정보통신부(2020), 2020 인터넷이용실태조사

2) 프레임

가) 가구용

- 인터넷이용실태조사 가구조사에서는 가구의 일반적인 특성과 정보통신 기기 및 서 비스 이용 현황 정보가 수집됨

〈표 3-12〉 인터넷이용실태조사 - 가구조사 프레임

\begin{tabular}{|c|c|}
\hline 주요 구분 & 세부 내용 \\
\hline 가구 특성 & 가구원 정보, 가구 월평균 소득 \\
\hline \multirow{2}{*}{ 정보기기 설치 현황 } & 정보통신 기기의 보유 현황 및 인터넷 환경 \\
\hline & (인터넷 비접속 가구) 인터넷에 접속하지 않는 이유 \\
\hline $\begin{array}{c}\text { 정보통신 서비스 } \\
\text { 이용 현황 }\end{array}$ & 집에서 이용 가능한 정보통신 서비스 현황(전화, 인터넷, TV, 방송, 스마트홈 서비스) \\
\hline
\end{tabular}

자료: 과학기술정보통신부(2020), 2020 인터넷이용실태조사 
나) 개인용(가구원용)

- 인터넷이용실태조사 개인조사에서는 가구원 개인의 인터넷 이용현황 및 이용행태 를 중심으로, 일상생활에서 인터넷 활용, 인터넷의 사회적 영향 등을 파악할 수 있 는 내용으로 구성됨

〈표 3-13〉 인터넷이용실태조사 - 개인조사 프레임

\begin{tabular}{c|l}
\hline 주요 구분 & \multicolumn{1}{c}{ 세부 내용 } \\
\hline 기기 보유 및 이용 현황 & $\begin{array}{l}\text { 컴퓨터, 정보통신 기기, 웨어러블 기기, 스마트폰 보유 및 이용 현황, } \\
\text { 이용 시점, 빈도, 활용 능력 }\end{array}$ \\
\hline 인터넷 이용 현황 & 이용 빈도, 시간, 장소, 목적 등 \\
\hline 인터넷 이용 환경 & 가구, 개인의 정보통신기기 보유 및 인터넷 접속 \\
\hline 인터넷 커뮤니케이션 현황 & 인스턴트 메신저, SNS, 이메일 이용 매체 및 이용 빈도, 시간, 서비스 등 \\
\hline 인터넷 경제활동 현황 & 인터넷 쇼핑, 인터넷 뱅킹 이용 현황 등 \\
\hline $\begin{array}{c}\text { 인터넷을 이용하지 않는 이유 및 } \\
\text { 향후 이용의향 }\end{array}$ & (인터넷 비이용자 대상) \\
\hline
\end{tabular}

자료: 과학기술정보통신부, 한국인터넷진흥원(2018), 2018 인터넷이용실태조사 보고서

- 최근에는 온라인 플랫폼에서 발생하는 거래, 정보교환 등과 관련된 사회적 논의가 활발해지고 있는 추세임을 고려할 때, 인터넷을 중심으로 한 이용자들의 축적된 정보로서 가치가 매우 높은 조사 구조로 볼 수 있으나, 동시에, 인터넷 이외의 융 합적 이용행위를 종합적으로 파악하기에는 한계가 있음

- 특히 본 조사를 통해 꾸준히 측정할 수 있는 정책 내용이 구성되지는 않음

\section{바. 방송매체이용행태조사}

\section{1) 조사 특성}

- 방송매체이용행태조사는 다양한 시·청취 매체에 대한 이용자의 행태와 인식 변화 를 정기적으로 분석하여, 방송시청 환경 변화에 따른 이용행태 변화를 파악하는 것을 목적으로 하는 조사임

- 이에 따라 조사대상은 전국 만 13 세 이상 인구이며, 표본으로 선정된 가구의 가구원 전체를 조사함

- 전반적으로 ‘방송’에 특화된 이용 환경과 행태 정보 수집 구조를 갖춤 
- 이에 따라 라디오, 방송, 온라인 동영상 콘텐츠(OTT), 음성인식 인공지능 기기 등 방송 환경의 변화에 따른 시·청취 기기 및 이용행태 정보가 수집됨

〈표 3-14〉 방송매체이용행태조사 조사표

\begin{tabular}{|c|c|c|c|c|c|c|}
\hline 작성주체 & 조사대상 & 주기 & 연혁 & 표본규모 & 표본추출 & 자료배열 \\
\hline 방송통신위원회 & 전국 만 13세 이상 & 1년 & $\begin{array}{l}\text { 2000년 } \\
\text { - 현재 }\end{array}$ & $\begin{array}{c}, 042 \text { 가구 } \\
(6,029 \text { 명 })\end{array}$ & $\begin{array}{l}\text { 다단계 층화 } \\
\text { 집락 확률표집 }\end{array}$ & 횡단 \\
\hline
\end{tabular}

자료: 방송통신위원회(2020), 2020 방송매체이용행태조사

2) 프레임

가) 가구용

- 방송 관련 정책을 검토할 수 있는 내용으로서, 자녀(만 13세 미만 미성년 자녀)의 방송 매체 이용행태, 가족 구성원의 동반 시청 행태, 그리고 비상상황시 우선 이용 하거나 의존할 매체 등에 대한 정보를 수집하고 있음

〈표 3-15〉 방송매체이용행태조사 - 가구조사 프레임

\begin{tabular}{|c|c|}
\hline 주요 구분 & 세부 내용 \\
\hline 가구 특성 & 가구원 특성(성, 연령, 학력, 직업, 혼인상태 등), 소득, 지역, 가구유형, 월평균 통신료 등 \\
\hline $\begin{array}{c}\text { 매체 보유와 유료방송 } \\
\text { 가입현황 및 } \\
\text { 시청행태 }\end{array}$ & $\begin{array}{l}\text { TV수상기, 라디오 수신기, 컴퓨터/스마트패드, 차량용 DMB 단말기, DVD 플레이어, } \\
\text { 디지털 카메라 캠코더, 가구 보유형 게임기, 스마트형 TV수신장치, 음성인식 인공지능 } \\
\text { 기기, 가정용 전화회선, 케이블방송, 디지털 위성방송 스카이라이프, IPTV 가입 여부, 무료 } \\
\text { 지상파 방송 시청 기기 여부(TV수상기, PC모니터, 노트북, 빌트인TV) 등 }\end{array}$ \\
\hline 용 & 만 13세 미만 자녀 유무 및 해당 자녀의 연령, 자녀의 방 \\
\hline
\end{tabular}

자료: 방송통신위원회(2020), 2020 방송매체이용행태조사

나) 개인용(가구원용)

- 개인조사에서는 '방송' 분야에 특화된 정보를 '기기', '채널', ‘프로그램' 등의 층위 별로 매우 상세한 정보를 수집할 수 있도록 구성된 강점이 있음

- 이러한 점은 콘텐츠 타 장르를 과감하게 제거하고, '방송' 분야에 특화된 세밀한 통계 작성을 목적으로 한 조사의 강점이라고 볼 수 있음 
〈표 3-16〉 방송매체이용행태조사 - 개인조사 프레임

\begin{tabular}{|c|c|}
\hline 주요 구분 & 세부 내용 \\
\hline 유료방송 가입여부 & 케이블 방송, 디지털 위성방송, IPTV 가입 여부 \\
\hline 매체 보유 및 이용 현황 & $\begin{array}{l}\text { 보유 기기 대수 및 미디어 기기, 음성인식 인공지능 기기 이용 빈도, } \\
\text { 라디오·방송·온라인 동영상 콘텐츠(OT)·지상파DMB·스마트기기·해외제작방송프로그 } \\
\text { 램·타매체 이용행태 등 }\end{array}$ \\
\hline $\begin{array}{l}\text { 가족 구성원 } \\
\text { 동반 시청 행태 }\end{array}$ & $\begin{array}{l}\text { 가족 구성원들과 함께 시청하는 프로그램 유형 및 시청 빈도 } \\
\text { (뉴스, 드라마, 스포츠, 시사·교양, 오락·연예, 영화) }\end{array}$ \\
\hline $\begin{array}{c}\text { 매체 이용 시간, 장소, } \\
\text { 매체 }\end{array}$ & $\begin{array}{l}\text { 하루 동안 사용했던 미디어 이용 활동을 } 20 \text { 분 단위마다 기록 } \\
\text { (이용 장소, 이용 매체 포함) }\end{array}$ \\
\hline 매체 이용 인식 & 방송프로그램 시청에 대한 견해, 비상상황시 우선 이용하거나 의존할 매체 등 \\
\hline
\end{tabular}

자료: 방송통신위원회(2019), 2019 방송매체이용행태조사 보고서

\section{사. 청소년 매체이용 및 유해환경 실태조사}

\section{1) 조사 특성}

- 청소년 매체이용 및 유해환경 실태조사의 목적은 청소년보호와 관련한 정책 대응 의 기초자료로 활용하고자 하는 것임

- 이를 위해 조사대상을 전국의 초·중·고등학생으로 설정하고, 표본으로 선정된 학교를 방문하여 1 개 학교에서 1 개 학년 1 개 학급을 집단조사 방식임

〈표 3-17〉 청소년 매체이용 및 유해환경 실태조사 조사표

\begin{tabular}{c|c|c|c|c|c|c}
\hline 작성주체 & 조사대상 & 주기 & 연혁 & 표본규모 & 표본추출 & 자료배열 \\
\hline 여성가족부 & 전국 초4 고3 학생 & 2년 & $\begin{array}{c}1999 \text { 년 } \\
- \text { 현재 }\end{array}$ & $\begin{array}{c}\text { 633개 학교 } \\
(14,536 \text { 명 학생 })\end{array}$ & $\begin{array}{c}\text { 다단계 층화 } \\
\text { 집락 확률표집 }\end{array}$ & 횡단 \\
\hline
\end{tabular}

자료: 여성가족부(2020), 2020 청소년매체이용및유해환경실태조사

\section{2) 프레임}

- 청소년 매체이용 및 유해환경 실태조사는 청소년이 노출되는 위험요인으로서 성인 용 영상물, 온라인 게임, 청소년 (성)폭력, 가출 등의 경험과 청소년의 자율성, 친구 관계, 학교 교사에 대한 인식 등 사회자본 간의 관계를 중점적으로 검토할 수 있도 록 구성되어 있음

- 콘텐츠 이용행태를 전반적으로 파악하기보다, ‘성인용 영상물'이나 ‘온라인 게임', 
'전자오락실, $\mathrm{PC}$ 방, 노래방, VR 체험카페' 등 일부 콘텐츠의 이용 경험이 청소년 에게 유해할 가능성이 있음을 전제로, 설계한 구조임

- 온라인 게임, $\mathrm{PC}$ 방, 노래방, $\mathrm{VR}$ 체험카페 등 콘텐츠 이용과 관련한 온·오프라 인 노출, 이용 경험이 반드시 청소년에게 유해하다고 보기는 어렵지만, 이용의 정도, 청소년 개인의 사회경제적 환경 조건 등을 두루 검토할 때, 관련 보호정책 을 개발할 수 있는 가능성은 높은 자료 구조라 할 수 있음

〈표 3-18〉 청소년 매체이용 및 유해환경 실태조사 프레임

\begin{tabular}{c|l}
\hline 주요 구분 & \multicolumn{1}{|c}{ 세부 내용 } \\
\hline 매체 관련 & $\begin{array}{l}\text { - 매체 이용 경험, 빈도, 주로 이용하는 기기 } \\
\text { - 성인용 영상물(청소년 관람불가, 19세이상 시청 가), 온라인 게임 등 접촉 경험, 경로 등 }\end{array}$ \\
\hline 행위 관련 & $\begin{array}{l}\text { - 청소년폭력, 청소년 성폭력, 가출 경험 } \\
\text { - 청소년 보호기관 인지여부, 이용 여부, 교육 경험 등 }\end{array}$ \\
\hline 약물 관련 & - 술, 담배, 환각성 물질, 고카페인 유해물질 접촉 경험, 경로 등 \\
\hline 업소 관련 & - 전자오락실, 술집, PC방, 노래방, 찜질방, VR 체험카페 등 이용 경험, 경로, 노출 정도 등 \\
\hline 사회인구학적 & - 성, 연령, 함게 거주하는 사람 등 \\
특성 & - 아르바이트 등 근로 경험 \\
\hline 사회적 관계 & - 자율성, 친구, 학교교사에 대한 인식 \\
\hline
\end{tabular}

자료: 방송통신위원회(2019), 2019 방송매체이용행태조사 보고서

\section{2. 주요 실태조사}

\section{가. 웹소설이용자실태조사}

1) 조사 특성

- 웹소설이용자실태조사는 웹소설 이용자들의 특성과 소비행태를 파악하여 관련 업 계 및 정책 입안자들이 활용할 수 있는 기초통계 제공을 목적으로 함

- 조사대상은 만 10 세 59세의 일반 국민 중 웹소설 이용자 2,000명, 미이용자 1,000 명으로 설정됨

- 표집틀은 조사수행기관의 모바일 무작위 추출 패널자료를 활용함 
〈표 3-19〉 웹소설이용자실태조사 조사표

\begin{tabular}{c|c|c|c|c|c|c}
\hline 작성주체 & 조사대상 & 주기 & 연혁 & 표본규모 & 표본추출 & 자료배열 \\
\hline 한국콘텐츠진흥원 & $\begin{array}{c}\text { 만 10세 이상 } \\
\text { 59세 이하 }\end{array}$ & - & 2020년 & $\begin{array}{c}\text { 이용자 2,008명 } \\
\text { 미이용자 1,330명 }\end{array}$ & $\begin{array}{c}\text { 성별/연령별/지역별 } \\
\text { 할당표집 }\end{array}$ & 횡단 \\
\hline
\end{tabular}

자료: 한국콘텐츠진흥원(2020), 2020 웹소설이용자실태조사

\section{2) 프레임}

- 웹소설이용자실태조사는 전체적으로 웹소설 이용자와 미이용자의 이용 동향을 파 악할 수 있도록 구성됨

- 웹소설 이용자를 대상으로는 세부적으로 웹소설 이용 장르를 파악할 수 있도록, 미이용자를 대상으로는 평소 독서 성향과 같은 ‘취향(또는 성향)' 정보를 수집하 고 있다는 강점이 있음

- 웹소설 산업계와 정책 양 측면에서 모두 주목할만한 내용으로, 웹소설 관련 2차 저작물 이용에 대한 현황, 관련 상품의 구입 의향 정보를 수집하고 있음

- 이러한 정보가 장기적으로 축적될 경우, 웹소설을 원작으로 한 드라마, 영화, 오디오북 등 다른 형태의 콘텐츠 개발에 유용한 정보로 활용될 수 있음

- 최근 조사에서는 코로나 발생으로 인한 여가시간 및 웹소설 이용량의 변화, 향 후 웹소설 이용량 변화에 대한 의향 등 웹소설 이용자들에 대한 코로나 영향을 파악하고자 하는 내용이 추가 설계됨

〈표 3-20〉 웹소설이용자실태조사 프레임

\begin{tabular}{c|l}
\hline 구분 항목 & \multicolumn{1}{c}{ 세부 내용 } \\
\hline 사회인구학적 특성 & 성, 연령, 지역, 소득, 직업 \\
\hline $\begin{array}{c}\text { 웹소설 이용 의향 } \\
\text { (미이용자 대상) }\end{array}$ & 평소 독서 성향, 향후 이용 의향 등 \\
\hline $\begin{array}{c}\text { 웹소설 이용 현황 } \\
\text { (이용자 대상) }\end{array}$ & $\begin{array}{l}\text { 이용 웹소설 플랫폼, 작품, 이용시간, 기기, 결재금액, } \\
\text { 웹소설 선택시 중요하게 고려하는 기준, 유료이용 관련 등 }\end{array}$ \\
\hline 2차적 저작물 이용 & $\begin{array}{l}\text { 원작이 웬소설인 드라마 인지 여부, 오디오북, ㅇㅞㅞ툰, 드라마, 영화, 유튜브 등 } \\
\text { 타 콘텐츠 중 웹소설로 제작되면 좋겠다고 생각한 콘텐ㄴㅊㅡ 등 }\end{array}$ \\
\hline 웹소설 관련 상품 구입 의향 & 감상한 웹소설과 관련된 상품이 판매되는 경우 구입할 의향, 선호하는 상품 \\
\hline $\begin{array}{c}\text { 코로나19 이후의 웹소설 } \\
\text { 이용변화 }\end{array}$ & $\begin{array}{l}\text { 코로나19 이후 여가시간 변화, 웹소설 이용량 변화, 코로나 종료 후 웹소설 이 } \\
\text { 용량 변화 예상 }\end{array}$ \\
\hline
\end{tabular}

자료: 한국콘텐츠진흥원(2020), 2020 웹소설이용자실태조사 보고서 


\section{나. 만화이용자실태조사}

1) 조사 특성

- 만화이용자실태조사는 만화에 대한 인식, 매체별 이용 및 구매 행태 등의 패턴을 비교 분석하는 것을 목적으로 하는 조사임

- 조사대상 모집단은 만 10세 59세의 일반 국민이며, 최근 1 년동안의 만화 콘텐 츠 이용자 3,000 명을 대상으로 조사를 진행함

- 디지털만화와 종이만화 이용 현황을 기초로, 이용 시간, 장소, 기기, 선호 장르 등 기초적인 만화 이용행태 정보, 만화관련 상품에 대한 구입 의향, 2 차 저작물 이용 관련 현황 정보를 수집함

〈표 3-21〉 만화이용자실태조사 조사표

\begin{tabular}{c|c|c|c|c|c|c}
\hline 작성주체 & 조사대상 & 주기 & 연혁 & 표본규모 & 표본추출 & 자료배열 \\
\hline 한국콘텐츠진흥원 & $\begin{array}{c}\text { 만 10세 이상 } \\
\text { 59세 이하 }\end{array}$ & 1년 & $\begin{array}{c}\text { 2019년 } \\
\text {-현재 }\end{array}$ & 3,000 명 & $\begin{array}{c}\text { 성별/연령별/지역별 } \\
\text { 할당표집 }\end{array}$ & 횡단 \\
\hline
\end{tabular}

자료: 한국콘텐츠진흥원(2020), 2020 만화이용자실태조사

2) 프레임

- 만화이용자실태조사의 특이점은 만화 장르에 특화된 '디지털 만화 불법이용' 관련 정보를 수집한다는 점임

- 정책 측면에서는 디지털 만화 불법이용과 관련한 이용자들의 행태 및 인식을 지속적으로 파악하여 새로운 정책을 수립할 수 있는 가능성을 확보함

- 최근 조사에서는 코로나 발생으로 인한 만화 이용의 변화를 파악하고자 하는 내용이 추가 설계됨

〈표 3-22〉 만화이용자실태조사 프레임

\begin{tabular}{c|l}
\hline 구분 항목 & \multicolumn{1}{c}{ 세부 내용 } \\
\hline 사회인구학적 특성 & 성, 연령, 지역 \\
\hline 만화 이용 현황 & $\begin{array}{l}\text { 디지털만화, 종이만화, 이용빈도, 시간(대), 장소, 기기, 서비스, 선택시 고려 } \\
\text { 기준, 즐겨보는 장르 등 }\end{array}$ \\
\hline 만화 관련 상품 구입 의향 & 종이만화, 캐릭터 상품 구매 경험, 지출비용 등 \\
\hline 만화 관련 인식 & 디지털만화 불법이용
\end{tabular}




\begin{tabular}{c|l}
\hline 구분 항목 & \multicolumn{1}{c}{ 세부 내용 } \\
\hline 2차적 저작물 이용 & $\begin{array}{l}\text { 만화 저작권 확장시 유료 이용 선호 콘텐츠, 최근 1년 유료 이용 콘텐츠, 장르 } \\
\text { 별 이용 비율 등 }\end{array}$ \\
\hline 코로나19 이후의 만화 이용변화 & $\begin{array}{l}\text { 코로나19 이후 만화 이용시간 증감, 이유, 유료이용의 증감, } \\
\text { 코로나 종료 후 만화 이용 증감 예상 등 }\end{array}$ \\
\hline
\end{tabular}

자료: 한국콘텐츠진흥원(2020), 2020 만화이용자실태조사

\section{다. 애니메이션이용자실태조사}

\section{1) 조사 특성}

- 애니매이션이용자실태조사는 전반적인 애니매이션 이용행태 및 인식을 파악해, 애 니매이션 콘텐츠 이용자 및 산업에 대한 합리적인 정책을 수립하고, 관련 산업 분 야의 개발, 생산 및 마케팅 활동을 지원하는 근거자료로 활용하는 것을 목적으로 하는 조사임

- 애니메이션 분야에 특화된 조사 자료가 극히 부족한 상황에서, 희귀성을 갖춘 강점 이 있음

〈표 3-23〉애니메이션이용자실태조사 조사표

\begin{tabular}{c|c|c|c|c|c|c}
\hline 작성주체 & 조사대상 & 주기 & 연혁 & 표본규모 & 표본추출 & 자료배열 \\
\hline 한국콘텐츠진흥원 & $\begin{array}{c}\text { 만 3세 이상 } \\
59 \text { 세 이하 }\end{array}$ & 1년 & $\begin{array}{c}2019 \text { 년 } \\
\text { 현재 }\end{array}$ & 3,000 명 & $\begin{array}{c}\text { 성별/연령별/지역별 } \\
\text { 할당표집 }\end{array}$ & 횡단 \\
\hline
\end{tabular}

자료: 한국콘텐츠진흥원(2020), 2020 애니메이션이용자실태조사

\section{2) 프레임}

- 애니메이션이용자실태조사는 애니메이션 최종 품목이 주로 '영상' 형태라는 점을 반영하여, 시청 방법, OTT를 통한 시청 경험, 정보취득 경로, 기기 이용, 유료 이 용, 이용 시간, 2 차 저작물 유료구매 경험 등의 정보를 간결한 구조로 수집하도록 설계됨

- 최근 조사에서는 코로나 발생으로 인한 애니메이션 이용 변화와 영향을 파악하고 자 하는 내용이 추가 설계됨 
〈표 3-24〉애니메이션이용자실태조사 프레임

\begin{tabular}{c|l}
\hline 구분 항목 & \multicolumn{1}{c}{ 세부 내용 } \\
\hline 사회인구학적 특성 & $\begin{array}{l}\text { - 성, 연령, 지역 } \\
- \text { 애니메이션 시청시 월평균 소비 가능 금액 }\end{array}$ \\
\hline \multirow{3}{*}{ 애니메이션 이용 현황 } & $\begin{array}{l}\text { 시청 방법, OT를 통한 시청 경험, 애니메이션 이용 선택기준 및 정보취득 } \\
\text { 경로, 시청 빈도, 시간(대), 유료이용 경험, } \\
\text { 극장용 애니메이션, 스마트기기, DVD/블루레이 이용 경험 전반 등 }\end{array}$ \\
\hline 2차적 저작물 이용 & $\begin{array}{l}\text { 애니메이션 저작권 확장시 다른 콘텐츠 이용 경험, 최근 1년 이용 콘텐츠, 이 } \\
\text { 용비중, 유료구매 콘텐츠 등 }\end{array}$ \\
\hline $\begin{array}{c}\text { 코로나19 이후의 애니메이션 } \\
\text { 이용변화 }\end{array}$ & $\begin{array}{l}\text { 코로나19 이후 애니메이션 시청시간 증감, 이유, 유료이용의 증감, } \\
\text { 캐릭터 상품 구매 경험, 코로나 종료 후 만화 이용 증감 예상 등 }\end{array}$ \\
\hline
\end{tabular}

자료: 한국콘텐츠진흥원(2020), 2020 애니메이션이용자실태조사

\section{라. 캐릭터이용자실태조사}

\section{1) 조사 특성}

- 캐릭터이용자실태조사는 캐릭터 콘텐츠 이용자 및 산업에 대한 합리적 정책을 수 립하고 캐릭터 산업 분야의 개발, 생산 및 마케팅 활동을 지원하는 자료로 활용하 는 것을 목적으로 하는 조사임

- 캐릭터 분야에 특화된 조사 자료가 극히 부족한 상황에서 작성된 자료라는 강점이 있음

〈표 3-25〉 캐릭터이용자실태조사 조사표

\begin{tabular}{c|c|c|c|c|c|c}
\hline 작성주체 & 대상 & 주기 & 연혁 & 표본규모 & 표본추출방법 & 자료배열 \\
\hline 한국콘텐츠진흥원 & $\begin{array}{c}\text { 만 3세 이상 } \\
\text { 59세 이하 }\end{array}$ & 1년 & $\begin{array}{c}\text { 2019년 } \\
- \text { 현재 }\end{array}$ & 3,000 명 & $\begin{array}{c}\text { 성별/연령별/지역별 } \\
\text { 할당표집 }\end{array}$ & 횡단 \\
\hline
\end{tabular}

자료: 한국콘텐츠진흥원(2020), 2020 캐릭터이용자실태조사

2) 프레임

- 캐릭터이용자조사는 이용자들의 전반적인 캐릭터 이용 인지 및 선호도, 온·오프라 인·전문스토어 이용과 구매 현황을 중심으로, 불법·정품 캐릭터 상품 구별 가능 여부 등 상품 이용 인식, 2차 저작물 이용 현황 정보를 수집하는 구조로 설계됨

- 최근 조사에서는 코로나 발생으로 인한 캐릭터 이용 변화와 영향을 파악하고자 하 는 내용이 추가 설계됨 
〈표 3-26〉 캐릭터이용자조사 프레임

\begin{tabular}{c|l}
\hline 구분 항목 & \multicolumn{1}{c}{ 세부 내용 } \\
\hline 사회인구학적 특성 & $\begin{array}{l}\text { - 성, 연령, 지역 } \\
\text { 캐릭터 콘텐츠 소비 가능 수준(월평균, 연평균) }\end{array}$ \\
\hline 캐릭터 이용 현황 & $\begin{array}{l}\text { 캐릭터 인지 및 선호도, 경로, 상품 구매 경험 전반(상품군, 지출금액, 장소, 목 } \\
\text { 적 등), 모바일·오프라인(전시회, 행사)·전문스토어 이용 경험 전반 }\end{array}$ \\
\hline 캐릭터 상품 이용 인식 & $\begin{array}{l}\text { 캐릭터 구매 결정 영향 여부, 캐릭터 부착상품 비용 추가지불 의사, 가능범위, } \\
\text { 불법·정품 구별 가능 여부, 방법 등 }\end{array}$ \\
\hline 2차적 저작물 이용 & $\begin{array}{l}\text { 캐릭터 저작권 확장시 유료이용 선호 콘텐츠, 최근 1년 이용 콘텐츠, 유료구매, } \\
\text { 다른 콘텐츠 이용 경험 등 }\end{array}$ \\
\hline 코로나19 이후의 캐릭터 & $\begin{array}{l}\text { 코로나19 이후 캐릭터 상품구매 비용 증감, 이유, 모바일 캐릭터 이용 증감, } \\
\text { 캐리용변화 전문스토어 방문 증감(횟수) 등 }\end{array}$ \\
\hline
\end{tabular}

자료: 한국콘텐츠진흥원(2020), 2020 캐릭터이용자실태조사

\section{마. 게임이용자패널연구}

1) 조사 특성

- 게임이용자패널조사는 게임중독의 기준과 양상을 규명하고, 게임이 이용자에게 미 치는 영향 변수에 대한 효과를 검증하여 게임 인식을 제고하고, 학술 및 정책 아젠 다를 구성하는 것을 목적으로 하는 조사임

- 조사대상이 3년 단위로 상급학교에 진학하는 학생들이라는 특징을 고려하여, 3년 이하의 초단기 패널로 코호트 연령대를 구성하였으며, 해당 학생과 학부모를 함께 조사하는 종단 구조임

- 조사주기는 매년 2회, 반기별 조사로, 여름에 실시하는 상반기 조사, 겨울에 실시 하는 하반기 조사가 각 그룹별 패널을 운영하고 있는데, 이러한 조사주기 또한 조 사대상의 학년, 신규 학급 등의 변화를 반영한 것임

〈표 3-27〉 게임이용자패널연구 조사표

\begin{tabular}{c|c|c|c|c|c|c}
\hline 작성주체 & 대상 & 주기 & 연혁 & 표본규모 & 표본추출방법 & 자료배열 \\
\hline $\begin{array}{c}\text { 한국콘텐츠진 } \\
\text { 흥원 }\end{array}$ & $\begin{array}{c}\text { 1차년도(2014년) 기준 } \\
\text { 초4, 중1, 고1 }\end{array}$ & $\begin{array}{c}\text { 1년에 } \\
\text { 2회 }\end{array}$ & $\begin{array}{c}\text { 2014년- } \\
\text { 현재 }\end{array}$ & $\begin{array}{c}\text { 상반기 2,000명 } \\
\text { 하반기 1,728명 }\end{array}$ & 임의표집 & 종단 \\
\hline
\end{tabular}

자료: 한국콘텐츠진흥원(2018), 2018 게임이용자 패널 5차년도 연구 
2) 프레임

- 게임이용자패널조사의 목적에 명시되었듯, 게임이 이용자에게 미치는 영향 요인을 파악할 수 있는 개인적, 환경적 정보를 폭넓게 수집하고 있음

- 게임이 이용자에게 미치는 영향을 설명하는데 있어, 의학, 사회과학 등 다양한 분 야에서 인과관계를 규명하고자 하는 노력이 활발한 편임을 고려할 때, 게임이용자 패널조사에 구성된 정보는 매우 유용할 수 있음

- 초기 패널이 '청소년', '게임이용자'로 구성된 점은 다소 아쉬운 점이나, 예산 및 인력 등 현실적인 이유가 작용하였을 가능성이 있음. 게임을 이용하지 않는 사람들도 함께 비교 검토할 수 있도록 설계되었다면, 보다 폭넓은 정보 수집과 실증 분석 가능성이 확보될 수 있음

- 코로나 이전에는 게임이 과몰입 등 문제를 중심으로 다뤼져 온 바 있으나, 코로나 이후 게임이 사회적 상호작용에 주는 효과 측면에 대한 관심도 높아진만큼, 더 많 은 연구와 논의를 위해 운영 측면에 보완과 지원이 필요할 것임

〈표 3-28〉 게임이용자패널조사 프레임

\begin{tabular}{c|l}
\hline 구분 항목 & \multicolumn{1}{c}{ 세부 내용 } \\
\hline 사회인구학적 특성 & $\begin{array}{l}\text { - 성, 연령, 지역 } \\
\text { 콘텐츠 소비 가능 수준(월평균, 연평균) }\end{array}$ \\
\hline 게임 이용 현황 & 게임 이용동기, 커뮤니티 활동, 플레이유형, 미디어·SNS 이용 \\
\hline 게임 이용 인식 & 게임 과몰입, 효능감, 규범성, 인식 등 \\
\hline $\begin{array}{c}\text { 게임이용자 내적요인 } \\
\text { (개인적 특성) }\end{array}$ & $\begin{array}{l}\text { 도덕성, 고독감, 우울감, 공격성, 자기통제, 성격, 물질적가치, 행복, 리더십, } \\
\text { 불안, 행복 등 }\end{array}$ \\
\hline $\begin{array}{c}\text { 게임이용자 외적요인 } \\
\text { (환경적 특성) }\end{array}$ & $\begin{array}{l}\text { 부모 양육 스타일, 개방적 의사소통, 학업·교우관계 스트레스, 교사지지, 또래 } \\
\text { 정서적지지, 부모와 친구의 게임 인식 }\end{array}$ \\
\hline 사회자본. & $\begin{array}{l}\text { 종교활동, 공부와 여가활동, 건강상태(건강, 운동, 체중관리, 식사습관 등 기본 } \\
\text { 라이프스타일·임상관찰 심리척도 }\end{array}$ \\
\hline
\end{tabular}

자료: 한국콘텐츠진흥원(2018), 2018 게임이용자 패널 5차년도 연구

\section{바. 게임이용자실태조사}

1) 조사 특성

- 게임이용자실태조사는 게임 산업의 최종 소비자인 게임 이용자의 게임 이용 현황 
및 게임에 대한 인식을 파악하여, 게임산업 육성과 투자 활성화를 위한 정책 수립 기초자료 제공을 목적으로 하는 조사임

〈표 3-29〉 게임이용자실태조사 조사표

\begin{tabular}{c|c|c|c|c|c|c}
\hline 작성주체 & 대상 & 주기 & 연혁 & 표본규모 & 표본추출방법 & 자료배열 \\
\hline 한국콘텐츠진흥원 & $\begin{array}{c}\text { 만 10세 이상 } \\
65 \text { 세 이하 }\end{array}$ & 1년 & $\begin{array}{c}\text { 2011년- } \\
\text { 현재 }\end{array}$ & $\begin{array}{c}\text { 이용자 2,165명 } \\
\text { 미이용자 } 919 \text { 명 }\end{array}$ & $\begin{array}{c}\text { 성별/연령별/지역별 } \\
\text { 할당표집 }\end{array}$ & 횡단 \\
\hline
\end{tabular}

자료: 한국콘텐츠진흥원(2020), 2020 게임이용자실태조사

\section{2) 프레임}

- 앞서 검토한 게임이용자패널조사는 가능한 한 동일한 응답자를 대상으로, 시간의 흐름에 따라 계속 추적조사를 할 수 있는 종단형 패널조사인것과 비교하여, 게임이 용자실태조사는 단년도 횡단면 조사라는 점에서 차이가 있음

- 게임이용자실태조사는 게임셧다운제도, 게임과 젠더 인식 간의 관계를 파악할 수 있는 등 이용자의 인식, 게임 관련 기술에 대한 의견, 자녀의 게임 이용에 대한 인식 및 태도 등에 대한 정보를 수집하고 있다는 특이성이 있음

〈표 3-30〉 게임이용자실태조사 프레임

\begin{tabular}{|c|c|}
\hline 구분 항목 & 세부 내용 \\
\hline 사회인구학적 특성 & $\begin{array}{l}\text { - 성, 연령, 지역, 직업, 결혼여부, 최종학력, 소득, 가족구성원 등 } \\
\text { - 캐릭터 콘텐츠 소비 가능 수준(월평균, 연평균) }\end{array}$ \\
\hline 게임 이용 현황 & $\begin{array}{l}\text { - 인터넷 접속 기기, 목적, } \mathrm{PC} \text { 방 이용 여부 및 실태 } \\
\text { - 이용 빈도, 장르, 시간, 개수, 기간, 구입비용, 지불경험 } \\
\text { - 확률형 아이템 관련 모바일 게임 등 }\end{array}$ \\
\hline 가상현실(VR)게임 이용 현황 & $\begin{array}{l}\text { - 가상현실 게임 구현 장비 이용현황, 경험, 시간, 비용, 게임장 재방문 의향, } \\
\text { 이용가격, 인식 등 }\end{array}$ \\
\hline $\begin{array}{c}\text { 게임 인식 및 태도 } \\
\text { (제도 및 사회일반 전반) }\end{array}$ & $\begin{array}{l}\text { - 셧다운제도 } \\
\text { - 게임 내 성인지 감수성 } \\
\text { - 게임 내 성희롱 및 성차별 피해경험 및 대응 방법 } \\
\text { - 실감형 게임, 클라우드 게임, 블록체인 게임에 대한 의견 } \\
\text { - 자녀의 게임 이용에 대한 인식 및 태도 }\end{array}$ \\
\hline
\end{tabular}

자료: 한국콘텐츠진흥원(2020), 2020 게임이용자실태조사 


\section{사. 음악이용자실태조사}

1) 조사 특성

- 음악이용자실태조사는 전반적인 음악 이용행태 및 인식을 조사하여, 음악 콘텐츠 이용자 및 산업에 대한 합리적 정책을 수립하고, 음악산업 분야의 개발, 생산 및 마케팅 활동을 지원하는 근거로 활용하는 것을 목적으로 하는 조사임

〈표 3-31〉 음악이용자실태조사 조사표

\begin{tabular}{c|c|c|c|c|c|c}
\hline 작성주체 & 대상 & 주기 & 연혁 & 표본규모 & 표본추출방법 & 자료배열 \\
\hline 한국콘텐츠진흥원 & $\begin{array}{c}\text { 만 10세 이상 } \\
\text { 59세 이하 }\end{array}$ & 1년 & $\begin{array}{c}\text { 2019년- } \\
\text { 현재 }\end{array}$ & 3,000 명 & $\begin{array}{c}\text { 성별/연령별/지역별 } \\
\text { 할당표집 }\end{array}$ & 횡단 \\
\hline
\end{tabular}

자료: 한국콘텐츠진흥원(2020), 2020 음악이용자실태조사

2) 프레임

- 음악이용자실태조사는 음악 이용의 빈도, 시간대, 장소, 이용수단이나 서비스, 기 기, 정보 취득 경로 뿐만 아니라, 음악 이용시 발생할 수 있는 구매 현황이나 유료 결재 현황에 대한 정보도 수집하고 있음

- 최근 조사에서는 코로나 발생으로 인한 음악, 비대면 공연 등 이용 변화를 파악할 수 있는 내용이 추가 설계됨

〈표 3-32〉 음악이용자실태조사 프레임

\begin{tabular}{|c|c|}
\hline 구분 항목 & 세부 내용 \\
\hline 사회인구학적 특성 & $\begin{array}{l}\text { - 성, 연령, 지역 } \\
\text { - 음악 콘텐츠 소비 가능 수준(월평균 금액) } \\
\end{array}$ \\
\hline 음악 이용 현황 & $\begin{array}{l}\text { - 음악 이용 빈도 } \\
\text { - 음악 감상 시간대, 장소, 이용수단·서비스, 기기, 구매비용, 관련 정보 취득경로 등 } \\
\text { - 온라인 음악·피지컬 음반·음악공연·음악 관련 온라인동영상·굿즈 및 } \mathrm{MD}, \text { 팬덤활 } \\
\text { 동, Al 스피커 등의 이용 현황(이용빈도, 방식, 유료결재 금액, 정보 취득경로, 이 } \\
\text { 유, 만족도 등) }\end{array}$ \\
\hline 2차적 저작물 이용 & $\begin{array}{l}\text { - 음악 저작권 확장시 유료이용 선호 콘텐츠, 최근 1년 이용 콘텐츠, 유료구매, 다른 } \\
\text { 콘텐츠 이용 경험 등 }\end{array}$ \\
\hline $\begin{array}{l}\text { 코로나 } 19 \text { 확산 이후 } \\
\text { 음악 이용 변화 }\end{array}$ & $\begin{array}{l}\text { - 코로나 } 19 \text { 이후 음악 이용 증감, 이유, 비대면 공연 감상 경험 및 장단점, 관람 } \\
\text { 유형 비중, 유료결제 의향, 음악감상 애로사항 등 }\end{array}$ \\
\hline
\end{tabular}

자료: 한국콘텐츠진흥원(2020), 2020 음악이용자실태조사 


\section{아. 지능정보사회이용자패널조사}

1) 조사 특성

- 지능정보사회이용자패널조사는 지능정보서비스에 대한 이용자의 사용경험과 권리 에 대한 의식을 연차별로 누적적으로 조사하고, 성, 계층, 세대, 지역 등 사회집단 별 맞춤형 이용자 정책을 구체화하는 것을 목적으로 함

〈표 3-33〉 지능정보사회이용자패널조사 조사표

\begin{tabular}{|c|c|c|c|c|c|c|}
\hline 작성기관 & 대상 & 주기 & 연혁 & 표본규모 & 표본추출방법 & 자료배열 \\
\hline 정보통신정책연구원 & $\begin{array}{l}\text { 만 17세 이상 } \\
\text { 64세 이하 }\end{array}$ & 1년 & $\begin{array}{c}\text { 2018년- } \\
\text { 현재 }\end{array}$ & 4,233명 & $\begin{array}{c}\text { 성별/연령별/지역별 } \\
\text { 할당표집 }\end{array}$ & 종단 \\
\hline
\end{tabular}

자료: 방송통신위원회(2019), 2019 지능정보사회이용자패널데이터 구축 및 조사

2) 프레임

- 지능정보사회이용자실태조사는 콘텐츠 이용을 '기기', '자동추천 콘텐츠의 이용', '검색엔진' 등의 사용 현황과 연관하여 파악할 수 있는 가능성이 있음

- 4차 산업혁명의 가장 큰 특징인 '지능정보사회’로의 진입을 고려하여, 디지털 기술 과 관련된 이용자들의 행태와 인식을 파악하고자 한 구조임

- 이 때문에 개인정보보호나 데이터·서버 이용 흔적(data trace), 사생활 보호, 인공지능 기술에 대한 이용자의 인식을 폭넓게 수집한다는 강점을 갖춤

- 그러나 콘텐츠의 구체적인 내용을 파악하기는 불가능한 구조임

- 조사목적이 콘텐츠 각 장르 구분을 크게 고려하지 않고 설정되어, 자료 자체에 대한 문제로 볼 수는 없음 
〈표 3-34〉 지능정보사회이용자실태조사 프레임

\begin{tabular}{|c|c|}
\hline 구분 항목 & 세부 내용 \\
\hline 사회인구학적 정보 & $\begin{array}{l}\text { - 성, 연령, 지역, 학력, 직업, 혼인상태, 가구원수, 주택종류, 생활수준, 월평 } \\
\text { 균 가구소득, 정치성향 등 }\end{array}$ \\
\hline $\begin{array}{c}\text { 디지털 기기 및 } \\
\text { 정보통신 서비스 사용 현황 }\end{array}$ & - 디지털 기기, 자동추천 서비스, 검색엔진 등에 대한 이용 경험 및 의견 \\
\hline $\begin{array}{l}\text { 지능정보기술 서비스 및 } \\
\text { 지능정보화 환경 평가 }\end{array}$ & $\begin{array}{l}\text { - 최신 기술 또는 서비스에 대한 관심 정도 및 향후 일상생활에서 가능한 일, } \\
\text { 미래 지능정보기술의 바람직성 정도 }\end{array}$ \\
\hline $\begin{array}{c}\text { 지능정보사회 이용자 보호 등 } \\
\text { 관련 정책 }\end{array}$ & $\begin{array}{l}\text { - 지능정보기술 발전 5년 내 현실화 여부에 대한 의견 } \\
\text { - 서버 이용 흔적(개인정보)에 대한 의견 } \\
\text { - 개인정보보호수준 } \\
\text { - 인공지능 확산으로 인한 심각성 인지 } \\
\text { - 이용자 권리에 대한 견해 } \\
\text { - 미래 개인 사생활 예상 등 }\end{array}$ \\
\hline 특화 이슈 & $\begin{array}{l}\text { - 인공지능 스피커(2018) } \\
\text { - OTT 등 동영상 서비스(2019) }\end{array}$ \\
\hline
\end{tabular}

자료: 방송통신위원회(2019), 2019 지능정보사회이용자패널데이터 구축 및 조사

\section{자. 언론수용자조사}

1) 조사 특성

- 언론수용자조사는 미디어 이용자의 행태 및 의식 변화 추이를 살펴봄으로써, 미디 어 이용자의 향후 미디어 이용 변화 양상, 미디어 산업 분야의 정책 수립, 미디어 관련 연구의 기초자료를 제공하는 것을 목적으로 하는 조사임

- 핵심적으로 '뉴스'에 집중하여, 뉴스 이용자들이 종이신문, 텔레비전, 라디오, 인터 넷, 포털, 메신저, SNS, 온라인 동영상 플랫폼, 팟캐스트와 같이 뉴스를 접촉하고 수용할 수 있는 미디어별, 각 플랫폼별 특성에 따른 이용 정보를 수집함

〈표 3-35〉언론수용자조사 조사표

\begin{tabular}{c|c|c|c|c|c|c}
\hline 작성주체 & 대상 & 주기 & 연혁 & 표본규모 & 표본추출방법 & 자료배열 \\
\hline 한국언론진흥재단 & 만 19세 이상 & 1년 & $\begin{array}{c}\text { 1984년- } \\
\text { 현재 }\end{array}$ & 5,010 명 & $\begin{array}{c}\text { 다단계 층화 } \\
\text { 집락 확률표집 }\end{array}$ & 횡단 \\
\hline
\end{tabular}

자료: 한국언론진흥재단(2020), 2020 언론수용자조사 
2) 프레임

- 언론수용자조사는 뉴스 이용 양상에 대한 정보를 각 매체별로 수집하는 구조라는 점에서 차별성과 강점을 갖춤

〈표 3-36〉 언론수용자조사 프레임

\begin{tabular}{c|l}
\hline 구분 항목 & \multicolumn{1}{c}{ 세부 내용 } \\
\hline 사회인구학적 정보 & - 성, 연령, 지역, \\
\hline & - 종이신문 이용행태 \\
& - 텔레비전 및 텔레비전 뉴스 이용 \\
& - 라디오 및 라디오 뉴스 이용 \\
& - 잡지 및 잡지 뉴스 이용 \\
& - 인터넷 및 인터넷 뉴스 이용 \\
& - 인터넷 포털 및 언론사 사이트 뉴스 이용 \\
& - 메신저 서비스 및 메신저 서비스 뉴스 이용 \\
& - SNS 및 SNS 뉴스 이용 \\
매체 이용행태 & - 온라인 동영상 플랫폼 및 온라인 동영상 플랫폼 뉴스 이용 \\
& - 팟캐스트 및 팟캐스트 뉴스 이용 \\
& - 뉴스 이용 경로 \\
\hline 언론과 언론인에 대한 평가 & - 언론 신뢰도 및 개선점 \\
\hline 사회 참여 & - 언론인, 직업군 평가 \\
\hline 종이신문 구독 & - 지난 1년간 사회 참여 경험 \\
\hline
\end{tabular}

자료: 한국언론진흥재단(2020), 2020 언론수용자조사

\section{차. 국민생활시간조사}

\section{1) 조사 특성}

- KBS 국민생활시간조사는 우리나라 국민들의 생활시간을 과학적으로 측정하고 체 계적으로 분석하여 미디어 정책 및 기업의 광고·홍보 전략 수립, 정책 기초자료로 활용할 것을 목적으로 하는 조사임

- 최근 조사인 2015년도 조사의 경우, 방송 환경의 변화를 반영할 수 있도록 아래와 같이 분류체계를 수정함

- 기존의 지상파TV와 유료방송 구분을 방송매체 '채널'을 중심으로 지상파TV, 유 료방송채널, 종합편성채널로 구분함

- 모바일 인터넷 활용 증가세를 고려하여, 인터넷으로 정의되었던 활동을 컴퓨터 와 휴대전화로 '기기' 기준으로 구분함 
- 또한, 스마트폰으로 대표되는 모바일 미디어의 확산을 고려하여, 통계청 생활시 간조사와 비교했을 때, 미디어 이용과 관련된 행태를 더 세분화함

- KBS 생활시간조사는 표본으로 선정된 개인이 하루 동안 한 일을 15 분 단위로 구 체적으로 기입하는 시간일지 구조임

- 데이터는 개인식별코드(ID) 1 개 당, 3 개의 행(row)에 연속적으로 정보가 축적 되는 형태로, 실증분석에서 이 점에 유의하지 않을 경우, 분석결과에 편향(bias) 이 발생할 수 있음

〈표 3-37〉 국민생활시간조사 조사표

\begin{tabular}{c|c|c|c|c|c|c}
\hline 작성주체 & 대상 & 주기 & 연혁 & 표본규모 & 표본추출방법 & 자료배열 \\
\hline $\begin{array}{c}\text { 서울대학교 언론정보 } \\
\text { 연구소 }\end{array}$ & 만 10세 이상 & 5년 & $\begin{array}{c}\text { 1980년- } \\
\text { 현재 }\end{array}$ & 3,408 명 & $\begin{array}{c}\text { 다단계 층화 } \\
\text { 집락 확률표집 }\end{array}$ & 횡단 \\
\hline
\end{tabular}

자료: 서울대학교 언론정보연구소(2015), 2015 국민생활시간조사

\section{2) 프레임}

- 콘텐츠 이용과 관련된 시간은 여가활동 시간과 다양한 매체별 이용 시간을 통해 주로 파악할 수 있음

- 매체별로 신문·잡지·책, 라디오, 지상파TV, 종합편성채널, 유료방송채널, 컴퓨 터, 휴대전화의 이용 시간을 구분하고 있음

- 다만 KBS 국민생활시간조사로 만화나 웹툰, 애니메이션, 캐릭터, 또는 최근에는 OTT 등 콘텐츠의 세부적인 이용양상을 구별하여 파악하기는 어려움

\section{〈표 3-38〉 KBS 국민생활시간조사 프레임}

\begin{tabular}{|c|c|}
\hline 주요 구분 & 세부 내용 \\
\hline \multirow{3}{*}{$\begin{array}{c}\text { 시간 } \\
\text { (일반행동. } \\
\text { 미디어행동. } \\
\text { 집에 있는 } \\
\text { 시간 구분) }\end{array}$} & 수면시간, 식사시간, 신변잡일, 일, 학업, 가사, 교제, 휴양, 이동 \\
\hline & $\begin{array}{l}\text { 여가활동(관람·감상, 스포츠, 승부놀이, 행락·산책, 취미활동, 기능·기술공부, 아이들 놀이, 음악 } \\
\text { 듣기, 동영상보기, 극장영화보기, 컴퓨터게임하기) }\end{array}$ \\
\hline & 신문·잡지·책, 라디오, 지상파TV, 종합편성채널, 유료방송채널, 컴퓨터, 휴대전화 \\
\hline 개인 특성 & $\begin{array}{l}\text { - 사회인구학적 특성(성, 연령, 학력, 직업), } \\
\text { - 가정에서 가입한 유료방송 서비스(케이블방송, 위성방송, IPTV, 혼합형, 가입서비스 없음) }\end{array}$ \\
\hline
\end{tabular}

자료: 서울대학교 언론정보연구소(2015), 2015 국민생활시간조사 


\section{제2절 시사점}

\section{1. 대표성을 갖춘 표본설계의 중요성}

- 본 장에서는 콘텐츠 이용자를 대상으로 작성된 주요 조사통계를 구체적으로 분석 하고자 하였음. 무엇보다 공공영역에서 생산하는 통계 자료는 신뢰성을 갖춘 정보 를 효과적으로 제공하는 역할이 중요함

- 본 장에서 콘텐츠 이용자를 대상으로 한 국가승인통계 7종, 주요 실태조사 10 종, 총 17 종의 주요 조사통계 자료의 표본설계 방법을 검토한 결과는 다음과 같음

- 현재 콘텐츠 이용자를 대상으로 한 다양한 형태의 데이터들 중에서도, 국가승인 조사통계일수록 확률표집 방법에 기반한 표본을 구성하여 대표성을 확보했다는 강 점이 있음

- 또한 대부분 횡단면 구조로 설계되어, 각 연도별 트렌드를 확인할 수 있는 정도 의 목적으로 작성되고 있음. 한국미디어패널조사가 콘텐츠 이용자를 대상으로 한 조사들 중에서는 유일한 종단면 구조라는 차별성을 갖추고 있음

- 동일한 조사대상을 가능한 한 지속적으로 추적조사하는 종단면 구조(패널)로 설 계할 경우, 장기적으로 보다 심층적인 정책 발굴과 검토가 가능하다는 점을 참 고할 수 있으나, 이를 위해서는 무엇보다 조사 예산과 인력 등 현실적인 조건이 마련되어야 할 것임

- 국가승인 조사통계 자료들은 가능한 한 조사대상의 연령대 폭을 넓혀, '청소년'과 같이 조사목적과 대상이 명확한 경우를 제외하면, 고연령층에 상한선을 설정하지 않고, 일반 국민의 정보를 최대한 수집하고자 했다는 점에서도 강점을 갖춤 
〈표 3-39〉 콘텐츠 이용자 대상 주요 국가승인통계

\begin{tabular}{|c|c|c|c|c|c|c|c|}
\hline 분야 & 조사명 & 대상 & 주기 & 연혁 & 표본규모 & 표본추출방법 & 자료배열 \\
\hline \multirow{2}{*}{ 문화 } & $\begin{array}{c}\text { 국민문화예술 } \\
\text { 활동조사 }\end{array}$ & 전국 만 15세 이상 & 1년 & $\begin{array}{l}\text { 1988년 } \\
\text { - 현재 }\end{array}$ & $\begin{array}{c}10,000 \text { 가구 } \\
(10,099 \text { 명 }) \\
※ \text { 99명 추가조사 }\end{array}$ & $\begin{array}{l}\text { 다단계 층화 } \\
\text { 집락 확률표집 }\end{array}$ & 횡단 \\
\hline & $\begin{array}{c}\text { 국민여가활동 } \\
\text { 조사 }\end{array}$ & 전국 만 15세 이상 & 1년 & $\begin{array}{l}\text { 2006년 } \\
\text { - 현재 }\end{array}$ & \begin{tabular}{|c|}
10,000 가구 \\
$(10,088$ 명 $)$ \\
$※$ 88명 추가조사
\end{tabular} & $\begin{array}{l}\text { 다단계 층화 } \\
\text { 집락 확률표집 }\end{array}$ & 횡단 \\
\hline 사회 & 생활시간조사 & 전국 만 10세 이상 & 5년 & $\begin{array}{l}\text { 1999년 } \\
\text { - 현재 }\end{array}$ & $\begin{array}{c}12,435 \text { 가구 } \\
(26,091 \text { 명 })\end{array}$ & $\begin{array}{c}\text { 다단계 층화 } \\
\text { 집락 확률표집 }\end{array}$ & 횡단 \\
\hline 미디어 & $\begin{array}{c}\text { 한국미디어 } \\
\text { 패널조사 }\end{array}$ & 전국 만 6세 이상 & 1년 & $\begin{array}{c}\text { 2010년 } \\
\text { - 현재 }\end{array}$ & $\begin{array}{l}4,260 \text { 가구 } \\
(10,302 \text { 명 })\end{array}$ & $\begin{array}{c}\text { 다단계 층화 } \\
\text { 집락 확률표집 }\end{array}$ & 종단 \\
\hline \multirow{2}{*}{ 과학기술 } & $\begin{array}{c}\text { 인터넷 } \\
\text { 이용실태조사 }\end{array}$ & 전국 만 3세 이상 & 1년 & $\begin{array}{l}\text { 1999년 } \\
\text { - 현재 }\end{array}$ & $\begin{array}{c}25,050 \text { 가구 } \\
(60,000 \text { 명 })\end{array}$ & $\begin{array}{c}\text { 다단계 층화 } \\
\text { 집락 확률표집 }\end{array}$ & 횡단 \\
\hline & $\begin{array}{c}\text { 방송매체 } \\
\text { 이용행태조사 }\end{array}$ & 전국 만 13세 이상 & 1년 & $\begin{array}{c}\text { 2000년 } \\
\text { - 현재 }\end{array}$ & $\begin{array}{c}4,042 \text { 가구 } \\
(6,029 \text { 명 })\end{array}$ & $\begin{array}{c}\text { 다단계 층화 } \\
\text { 집락 확률표집 }\end{array}$ & 횡단 \\
\hline 청소년 & $\begin{array}{c}\text { 청소년매체이 } \\
\text { 용및유해환경 } \\
\text { 실태조사 }\end{array}$ & 전국 초4 고3 학생 & 2년 & $\begin{array}{l}\text { 1999년 } \\
\text { - 현재 }\end{array}$ & $\begin{array}{c}\text { 633개 학교 } \\
(14,536 \text { 명 학생 })\end{array}$ & $\begin{array}{l}\text { 다단계 층화 } \\
\text { 집락 확률표집 }\end{array}$ & 횡단 \\
\hline
\end{tabular}

자료: 문화체육관광부(2020) 2020 국민문화예술활동조사;

문화체육관광부(2020) 2020 국민여가활동조사;

통계청(2019) 2019 생활시간조사;

정보통신정책연구원(2020) 2020 한국미디어패널조사;

과학기술정보통신부(2020) 2020 인터넷이용실태조사;

방송통신위원회(2020) 2020방송매체이용행태조사;

여성가족부(2020) 2020 청소년 매체이용 및 유해환경 실태조사 재정리

- 콘텐츠 각 장르별 실태조사들은 콘텐츠 이용의 특수성을 고려하여, 독립적인 개별 장르 이용자들에 한정된 조사들도 있어, 표본 대표성에 있어서는 국가승인통계 자 료에 비해 다소 부족하나, 그 필요성과 가치가 있다고 볼 수 있음

- 다만 자료의 대표성과 신뢰성을 보다 높이기 위해서 인구비례할당 표본을 구성할 수 있도록 표집틀이나 표본추출 및 보정 단계에 보완이 필요할 것임

- 추가적으로 표본 규모를 확대하거나, 조사통계 작성에 소요되는 예산과 시간적 여유를 제공하여 통계적 보정 가능성을 높이도록 지원이 필요함 
〈표 3-40〉 콘텐츠 이용자 대상 주요 실태조사(비승인통계)

\begin{tabular}{|c|c|c|c|c|c|c|c|}
\hline 분야 & 조사명 & 대상 & 주기 & 연혁 & 표본규모 & 표본추출방법 & 자료배열 \\
\hline \multirow{7}{*}{$\begin{array}{l}\text { 콘텐츠 } \\
\text { 산업 }\end{array}$} & \begin{tabular}{|c} 
웹소설이용자 \\
실태조사
\end{tabular} & $\begin{array}{l}\text { 만 10세 이상 } \\
\text { 59세 이하 }\end{array}$ & - & 2020년 & $\begin{array}{c}\text { 이용자 2,008명 } \\
\text { 미이용자 1,330명 }\end{array}$ & $\begin{array}{c}\text { 성별·연령별. } \\
\text { 지역별 } \\
\text { 할당표집 }\end{array}$ & 횡단 \\
\hline & $\begin{array}{l}\text { 만화이용자 } \\
\text { 실태조사 }\end{array}$ & $\begin{array}{l}\text { 만 10세 이상 } \\
\text { 59세 이하 }\end{array}$ & 1년 & $\begin{array}{c}\text { 2019년 } \\
\text {-현재 }\end{array}$ & 3,000명 & $\begin{array}{c}\text { 성별·연령별. } \\
\text { 지역별 } \\
\text { 할당표집 }\end{array}$ & 횡단 \\
\hline & $\begin{array}{c}\text { 애니메이션 } \\
\text { 이용자 } \\
\text { 실태조사 }\end{array}$ & $\begin{array}{l}\text { 만 3세 이상 } \\
\text { 59세 이하 }\end{array}$ & 1년 & $\begin{array}{l}\text { 2019년 } \\
\text { - 현재 }\end{array}$ & 3,000명 & $\begin{array}{c}\text { 성별·연령별· } \\
\text { 지역별 } \\
\text { 할당표집 }\end{array}$ & 횡단 \\
\hline & \begin{tabular}{|c|} 
캐릭터이용자 \\
실태조사
\end{tabular} & $\begin{array}{l}\text { 만 3세 이상 } \\
\text { 59세 이하 }\end{array}$ & 1년 & $\begin{array}{l}\text { 2019년 } \\
\text { - 현재 }\end{array}$ & 3,000명 & $\begin{array}{c}\text { 성별·연령별· } \\
\text { 지역별 } \\
\text { 할당표집 }\end{array}$ & 횡단 \\
\hline & $\begin{array}{c}\text { 게임이용자 } \\
\text { 패널연구 }\end{array}$ & $\begin{array}{l}\text { 1차년도(2014년) } \\
\text { 기준 초4, 중1, 고1 }\end{array}$ & $\begin{array}{l}\text { 1년에 } \\
\text { 2회 }\end{array}$ & $\begin{array}{c}\text { 2014년- } \\
\text { 현재 }\end{array}$ & $\begin{array}{l}\text { 상반기 } 2,000 \text { 명 } \\
\text { 하반기 } 1,728 \text { 명 }\end{array}$ & 임의표집 & 종단 \\
\hline & $\begin{array}{l}\text { 게임이용자 } \\
\text { 실태조사 }\end{array}$ & $\begin{array}{l}\text { 만 10세 이상 } \\
\text { 65세 이하 }\end{array}$ & 1년 & $\begin{array}{c}\text { 2011년- } \\
\text { 현재 }\end{array}$ & $\begin{array}{l}\text { 이용자 2,165명 } \\
\text { 미이용자 } 919 \text { 명 }\end{array}$ & $\begin{array}{c}\text { 성별·연령별· } \\
\text { 지역별 } \\
\text { 할당표집 }\end{array}$ & 횡단 \\
\hline & $\begin{array}{l}\text { 음악이용자 } \\
\text { 실태조사 }\end{array}$ & $\begin{array}{l}\text { 만 10세 이상 } \\
\text { 59세 이하 }\end{array}$ & 1년 & $\begin{array}{c}\text { 2019년- } \\
\text { 현재 }\end{array}$ & 3,000명 & $\begin{array}{c}\text { 성별·연령별· } \\
\text { 지역별 } \\
\text { 할당표집 }\end{array}$ & 횡단 \\
\hline 정보통신 & \begin{tabular}{|c|} 
지능정보사회 \\
이용자패널 \\
조사
\end{tabular} & $\begin{array}{l}\text { 만 17세 이상 } \\
\text { 64세 이하 }\end{array}$ & 1년 & $\begin{array}{c}\text { 2018년- } \\
\text { 현재 }\end{array}$ & 4,233명 & $\begin{array}{c}\text { 성별·연령별· } \\
\text { 지역별 } \\
\text { 할당표집 }\end{array}$ & 종단 \\
\hline 언론 & $\begin{array}{c}\text { 언론수용자 } \\
\text { 조사 }\end{array}$ & 만 19세 이상 & 1년 & $\begin{array}{c}\text { 1984년- } \\
\text { 현재 }\end{array}$ & 5,010 명 & \begin{tabular}{|c|} 
다단계 층화 \\
집락 확률표집
\end{tabular} & 횡단 \\
\hline 사회 & \begin{tabular}{|c|} 
국민생활시간 \\
조사
\end{tabular} & 만 10세 이상 & 5년 & $\begin{array}{c}\text { 1980년- } \\
\text { 현재 }\end{array}$ & 3,408명 & \begin{tabular}{|c|} 
다단계 층화 \\
집락 확률표집
\end{tabular} & 횡단 \\
\hline
\end{tabular}

자료: 한국콘텐츠진흥원(2020), 2020 웹소설이용자실태조사;

한국콘텐츠진흥원(2020), 2020 만화이용자실태조사;

한국콘텐츠진흥원(2020), 2020 애니메이션이용자실태조사;

한국콘텐츠진흥원(2020), 2020 캐릭터이용자실태조사;

한국콘텐츠진흥원(2018), 게임이용패널 5 차년도 연구;

한국콘텐츠진흥원(2020), 2020 게임이용자실태조사;

한국콘텐츠진흥원(2020), 2020 음악이용자실태조사;

방송통신위원회(2019), 지능정보사회 이용자 페널데이터 구축 및 조사;

한국언론진흥재단(2020), 2020 언론수용자조사;

서울대학교 언론정보연구소(2015), 2015 국민생활시간조사 자료 재정리

- 또한 콘텐츠와 콘텐츠 이용자들의 특수성에 대한 고려와 함께, 각 조사 자료들이 설계단계에서부터 가능한 한 표본 대표성을 갖출 수 있도록, 조사환경 변화에 대응

한 표본추출방법이나 자료수집방법 등에 대한 검토도 필요함 
- 조사통계의 대표성은 표본이 현실의 모집단 성격을 얼마나 잘 반영하도록 구성 되는지에 따라 좌우되는 면이 큰데, 이는 조사의 방법론적 측면 뿐만 아니라 조 사 내용과도 서로 밀접한 관계에 있음

〈표 3-41〉 콘텐츠 이용자 대상 주요 조사통계 표본의 특징

\begin{tabular}{|c|c|c|}
\hline 구분 & 국가승인통계 & 주요 실태조사(비승인통계) \\
\hline 목표모집단 & - 일반 국민 & $\begin{array}{l}\text { - 특정 콘텐츠 이용자 } \\
\text { - 특정 플랫폼, 채널, 프로그램, 상품 등 이용자 } \\
\text { - 비이용자(참조 비교집단) 포함 }\end{array}$ \\
\hline $\begin{array}{c}\text { 표집틀 } \\
\text { (조사모집단) }\end{array}$ & \begin{tabular}{|l|l} 
- 통계청 인구총조사 \\
(인구주택총조사, 등록센서스)
\end{tabular} & $\begin{array}{l}\text { - 조사기관(또는 회사) } \\
\text { 자체 보유 명부 }\end{array}$ \\
\hline 표본추출방법 & $\begin{array}{l}\text { - 확률표집 } \\
\text { (다단계 층화 집락 확률표집) }\end{array}$ & \begin{tabular}{|l} 
- 비확률표집 \\
(주민등록통계, \\
인구주택총조사 등 기준 \\
성별, 연령별, 지역별 \\
할당표집, \\
또는 조사지원자 모집) \\
\end{tabular} \\
\hline 자료수집방법 & - 면접조사 & $\begin{array}{l}\text { - 면접조사 } \\
\text { - 온라인조사 } \\
\text { - 면접조사+온라인조사 } \\
\end{array}$ \\
\hline 대표성 & $\begin{array}{l}\text { - 대표성 높은편 } \\
\text { - 확률이론 기반 } \\
\text { - 모수추정 가능 } \\
\end{array}$ & $\begin{array}{l}\text { - 다양함 } \\
\text { - 성별, 연령별, 지역별 구성비를 정확히 맞추더라도 } \\
\text { 편향(bias) 발생 가능 } \\
\end{array}$ \\
\hline 한계점 & $\begin{array}{l}\text { - 대부분 횡단면 반복조사 } \\
\text { - 관측하지 않은 응답자 특성을 반영 } \\
\text { 하여 분석할 수 없는 경우가 많음 }\end{array}$ & $\begin{array}{l}\text { - 대표성이 없는 표집틀로 인해 신뢰할 수 있는 모수 } \\
\text { 추정이 불가능한 경우가 많음 } \\
\text { (본 연구분석에 활용한 } \\
\text { 언론수용자조사, 국민생활시간조사 제외) }\end{array}$ \\
\hline 해결책 & $\begin{array}{l}\text { - 조사 수정 } \\
\text { - 조사 예산, 인력 등 지원 } \\
\text { - 매년 동일한 조사대상자를 반복조사 } \\
\text { 하는 추적조사(패널) 구축 }\end{array}$ & $\begin{array}{l}\text { - 표집틀 보완 } \\
\text { - 통계적 보정 } \\
\text { - 통계 작성 및 보정에 소요되는 예산, 인력, 시간적 } \\
\text { 여유 제공 }\end{array}$ \\
\hline
\end{tabular}

\section{2. 콘텐츠 이용행태 측정 프레임의 다양성}

- 콘텐츠 이용자를 대상으로 한 기존의 주요 조사통계 자료들의 내용 측면을 보다 심층 분석하기 위해 각 조사별 프레임을 검토한 결과, 대부분 '콘텐츠 이용행태' 중심의 정보를 수집하고자 하였음 
- 다만, 조사별로 목적에 따라 '콘텐츠 이용 범주’가 서로 다르게 구성되어, 콘텐 츠 장르 간 이용행태 변화를 검토할 수 있는 가능성이 결여됨

- 콘텐츠 이용행태를 구성하는 내용으로는 콘텐츠 이용 '시간' '기기', '지출' 관련 정보가 주를 이루었음

- 이는 소비자 선택 메커니즘에 대한 기초적인 이론틀로 활용되는 '시간할당론(A Theory of the Allocation of time)'(Becker, 1965)의 구성과 동일한 구조임 - 시간할당이론은 전통적인 소비 모델을 구성하는 '자원(재화)', '선택(구매)' 요인 에 '시간'이라는 제약요인을 추가하여, 시간의 가치가 결과적인 성과(취업여부 또는 구매여부 등)에 기회비용으로 작동하는 요인임을 설명하였음(Becker, 1965). 초기 연구들은 주로 노동시간에 대한 관심이 중점적이었으나, 점차 여 가시간, 이동시간 등 다양한 시간의 변화와 영향 관계에 대한 심층 분석으로 확 장되어왔음

- '시간' 요인은 모두에게 물리적으로 동등한 시간량이 각 개인의 사회경제적 조건에 따라 서로 다른 내용으로 구성되거나, 선택되며, 활용될 수 있다는 측면에서, 그 차 이를 설명하는 주요 요인으로 주목받게 된 바 있음(Gershuny et al., 1980; 2000) - 콘텐츠 분야에서는 전통적으로 방송 시청률 조사를 통해, 특정 채널이나 프로그 램의 시청 시간대, 시간량, 그에 따른 제반 조건을 측정해 온 사례가 해당될 수 있음

- '기기' 요인은 가정에 컴퓨터가 도입되면서 기존의 시간할당 패턴을 변화시키는 주요 요인으로 그 중요성이 높음(Votalari, Venkatesh, \& Gronhauh, 1985) - 결정적으로 컴퓨터와 같은 새로운 기술의 확산이 다양한 활동에 대한 시간 분배 를 가능하게 하고, 이로 인해 가정과 사회의 동학을 변화시킨다는 점에서 그 영 향력과 의미가 매우 크다는 것임

- 콘텐츠 분야에서는 컴퓨터(PC) 외에도 콘텐츠 이용에 연관된 $\mathrm{TV}$, 스마트폰 등 다양한 기기의 발전 뿐만 아니라, $\mathrm{mp} 3$ 음원의 유통, 스트리밍 서비스, OTT 플랫폼의 확산 등과 같은 산업 기술의 발전도 중요한 고려요소가 될 수 있음

- '지출' 요인은 콘텐츠 이용을 가능하게 하는 선행 조건으로 소득수준이나 구매력, 또는 특정 콘텐츠나 관련 상품의 소비를 발생시킨 결과로서 그 중요성이 높음 
- 콘텐츠 이용행태 측정과 관련하여, '시간할당론' 은 인터넷, 스마트폰 등과 같은 새 로운 미디어 환경 변화에 따라, 미디어 영역 내에서 뿐만 아니라 폭넓은 인간 행동 전반 차원에서의 고찰을 요구한다는 '시간 재할당 가설(Time reallocation hypothesis)'의 대두와도 관련성이 큼(이재현, 2013)

- 시간 재할당 가설은 새로운 미디어가 도입되고 활용되면서, 미디어 이용 시간을 포함해 생활시간 전반의 재분배가 이루어진다고 보는 것임

- 즉, 시간량은 동일하지만, 인터넷 이용과 함께 새로운 행동이 출현하고 그와 관 련된 이용 시간이 늘어나면, 전통 미디어의 이용 시간 또는 수면, 식사와 같은 필수 행동시간, 노동, 여가시간 등 삶의 전반에 걸친 다른 행동의 시간에 영향을 미치게 되며, 따라서 근본적으로 새로운 테크놀로지의 도입은 기능적인 대체를 발생시키기 보다 시간 구성의 재할당을 가져온다는 것임

- 이와 관련하여, 실제 동일한 시간대의 행위를 측정하는 ‘동시행동'에 있어, 콘텐 츠 이용의 측정치를 어떻게 처리하는 것이 바람직한 것인지에 대해서는 매우 다양한 이견이 있음

- 따라서 콘텐츠 이용행태를 구성하는 시간, 기기, 지출 등의 요인은 서로 영향관계 에 있다는 점에서 그 중요성이 높아, 대부분의 조사에서 측정의 주요 내용으로 구 성된 것이 확인되나, 본 연구에서 검토한 콘텐츠 이용자 대상 주요 조사통계 자료 상에서는 세부적인 측정 방식과 내용에 차이가 확인됨

- 주로 실태조사들을 통해서는 특정 콘텐츠 장르의 이용행태 정보를 집중적으로 수집하고 있으나, 장르 간 이용행태의 변화 양상이나 요인을 검토하기는 사실상 어려운 구조임

\section{3. 콘텐츠 이용 인과관계 측정 가능성 확대}

- 콘텐츠 이용행태를 중심으로, 인과관계를 검토할 수 있는 정보는 각 조사별로 다양 한 방법으로 수집되고 있었음. 다만 전반적으로 그 내용적 구성은 부족한 편으로 확인됨 
- 예를 들어, 콘텐츠 이용 또는 일상생활 전반에 대한 만족도와 같은 '심리적 요 인', '육체적 요인', '사회적 관계' 등 '삶의 질' 정보, '관련 정책에 대한 인식 여부나 만족도' '콘텐츠 산업 전반 또는 특정 콘텐츠 산업에 대한 향후 전망' 등과 같은 산업 정책 관련 정보가 조사별로 다양하게 측정되고 있었음

- 콘텐츠 이용행태와 이용자의 콘텐츠 이용 만족도, 또는 일반적인 삶의 만족도 정보 를 수집하는 경우가 많았는데, 이는 콘텐츠 이용이 궁극적으로 삶의 질 개선에 기 여한다는 관점에서 그 효과를 심층적으로 검토하기 위해 구성한 것으로 볼 수 있음 - 다만 '특정 콘텐츠 이용의 만족도 또는 인식'이나 '전반적인 삶의 질'은 조사별 로 측정 여부와 방식에 차이가 있어, 넓은 의미에서 삶의 질을 구성하는 요소가 다양한 형태로 측정되고 있는 상태로 이해할 수 있음

- 실제로 삶의 질을 구성하는 다양한 요인들은 인과관계 규명에 있어, 역 인과관 계, 즉 동일한 요인이 '결과'가 될 수도 있지만, '원인' 으로 작용할 수도 있다는 한계가 있음

- 그럼에도 불구하고, 최근 '개인(성)(personality, identity)'과 '삶의 질' 간의 관 계에 대한 사회적 관심이 확산되면서 전 세계적으로 물리적인 시간의 분배와 행동, 그리고 주관적 인식 간의 관계를 설명하고자 하는 연구가 많아진 추세를 반영한 것으로도 볼 수 있음(Robinson, 1983; Schulte, 2014)

- 콘텐츠 이용자 관점에서의 정책 관련 정보 수집 여부와 방식 또한 조사별로 차이가 있었음. 장기적으로 이용자 정책 수립과 검토를 고려한 내용 구성이 필요함

- 최근 콘텐츠 장르별 실태조사에서는 코로나 19 경험이 향후 특정 콘텐츠 장르의 이용량 증감이나 소비 전망에 미치는 영향에 대한 정보를 수집하고 있는데, 이 외에도 장기적으로 콘텐츠 이용자가 인식하는 산업 전망 정보를 체계적으로 수 집해야 할 필요가 있음 


\section{4. 조사 용어 정비의 필요성}

- 다음으로, 본 연구에서 콘텐츠 이용자 대상의 국가승인통계 및 주요 실태조사들의 조사문항을 정밀하게 검토하는 과정에서, 콘텐츠와 관련된 용어의 정비가 매우 필 요하다는 점을 확인함

- 콘텐츠 관련 용어가 혼재되고 있는 시례는 주로 콘텐츠를 이용하는 '기기', ‘매체', '서비스'를 지칭하는 내용이었음. 이 용어들은 조사별로 서로 다른 개념을 의미하 는 경우가 많았음

- '기기'는 대체로 콘텐츠를 이용하는 물리적 기기로서, TV(스마트TV), PC(컴퓨터, 노트북, 태블릿 PC, 컨버터블 PC), 스마트폰(휴대폰, 전화)이었으나, 조사마다 다 양한 용어로 구성되어 있었음

- '기기' 대신 '방법'이라는 용어가 사용되는 시례도 있었는데, 이 때 '방법’은 ‘콘 텐츠를 이용할 수 있는 기기 이용 방법'이라는 의미로, 주로 방송, 애니메이션 등 영상 관련 조사에서 활용되고 있었음. 대표적인 사례로, 방송매체이용실태조 사에서는 TV수상기, 데스크탑PC, 노트북, 스마트패드, 스마트폰, 지상파DMB 단말기와 같은 ‘기기’를 ‘방법’으로 지칭하였음

- 애니메이션이용자실태조사에서는 애니메이션을 시청할 수 있는 '기기'와 '공간' 을 포괄하여, TV모니터, 극장, 스마트기기, 기타로 구분하고 있었는데, 이는 애 니메이션 콘텐츠 이용에 특화된 시청 환경을 고려한 결과로도 이해할 수 있음. 실제로 애니메이션을 시청하는 '기기'와 ‘방법’을 구분하여 질문하였으나, 응답 자 관점에서 차이를 구별하기 어려울 수 있을 것으로 보임

- 음악이용자실태조사에서의 ‘방법'은 기기보다 '시·청취 방법’이나 ‘플랫폼' 의 의 미로, 음악서비스 사이트, 유튜브, 유튜브 외 온라인 동영상 서비스, SNS, P2P, 웹하드 등으로 구분되었음

- '매체' 또한, 한편으로는 주로 '기기'와 동일한 용어로 활용되었으나, 다른 한편에 서는 '플랫폼' 등 물리적 기기와 다른 층위에서 '서비스'를 의미하는 용어로 조사마 다 다양하게 사용되고 있었음

- 국민문화예술활동조사와 방송매체이용자행태조사에서 '매체'는 텔레비전, PC 
·노트북, 스마트기기, 비디오· $\mathrm{DVD} \cdot \mathrm{CD}$ 플레이어 같은 '기기'의 개념임

- 청소년 매체이용 및 유해환경 조사에서는 방송과 웹툰, 웹사이트, 메신저와 SNS 등 '플랫폼'이나 '서비스'를 포괄하는 의미로 사용되었음

- '매체'는 '미디어'를 지칭하는 용어로도 혼합적으로 사용되고 있었음

- 게임이용자패널조사에서 '미디어'는 '게임 이용행동'의 의미로, TV 시청, 독서 (종이책+eBook), 신문(종이), 라디오, 영화, 만화, 음악을 가리키고 있었음

- '서비스'는 '플랫폼'이라는 용어와 동일한 의미로 쓰이기도 하고, 별도의 다른 개념 으로 구분하여 쓰이기도 하였음

- 웹소설이용자실태조사에서 '서비스(플랫폼)'라는 표기는 '서비스'와 '플랫폼' 두 개념을 동일한 것으로 사용한 시례로, 이를 구성하는 하위 항목은 카카오페이 지, 네이버시리즈 등의 구체적인 콘텐츠 서비스로 구성됨

- 만화이용자실태조사에서는 '서비스'라는 용어를 사용하여 그 하위 항목은 네이 버웹툰, 다음웹툰 등을 의미하는 것으로 구성하였음

- 게임이용자실태조사에서는 '플랫폼'을 모바일(스마트폰) 기반 VR 게임, PC 기 반 VR 게임, 콘솔 게임기 기반 VR 게임, 독립형 VR 기기 기반 VR 게임으로 구분하여, 주로 게임 이용이 가능한 '기기'와 결합된 개념으로 사용되고 있었음 - 음악이용자실태조사에서는 '서비스' 용어에 대해서도 '음악 이용 경험의 수단 또는 서비스', '스트리밍 서비스', '온라인 동영상 서비스' 등으로 다양하게 분화 하여 사용하고 있었음. 각 질문에서 지칭하는 서비스가 '기기', ‘경로(채널)' 등 으로 다양하였으며, 음악 시·청취에 특화된 특정 '플랫폼' 서비스를 의미하는 경우도 있었음

〈표 3-42〉 콘텐츠 이용자 대상 조사 용어의 혼용 사례

\begin{tabular}{c|c|c}
\hline 조사 용어 & 혼용 용어 & 콘텐츠 조사 분야(장르) \\
\hline 기기 & 기기, 방법(이용행동, 경로), 플랫폼 & 방송, 애니메이션, 음악 \\
\hline 매체 & 기기, 플랫폼, 서비스, 미디어, 이용행동 & 문화예술활동, 방송, 게임 등 \\
\hline 서비스 & 플랫폼, 기기, 경로(채널) & 출판(웹소설), 만화, 게임, 음악 \\
\hline
\end{tabular}


콘텐츠 이용자 데이터 개발 기반연구

제4장

전문가 자문 분석 



\section{제1절 분석 개요}

\section{1. 분석 목적}

- 본 연구에서 앞서 콘텐츠 이용자를 대상으로 한 기존의 주요 조사통계 자료를 설계 방법과 내용 차원에서 분석하였음. 그 결과, 현재 콘텐츠 이용자 개인이 이용하는 다양한 장르의 콘텐츠 양상과 그 변화, 그리고 이와 영향을 주고 받을 수 있는 요 인들을 종합적으로 검토할 수 있는 자료가 없는 상태임을 확인하였음

- 본 장에서는 이러한 문제의식에 기반하여, 향후 콘텐츠 장르 간의 이용양상과 변화 를 이용자 관점에서 수집하고 검토할 수 있는 데이터 구축 가능성을 탐색함

\section{2. 분석 방법}

- 분석을 위한 자문위원은 콘텐츠 분야, 그리고 콘텐츠 이용양상에 관련한 데이터의 이해도가 높은 전문가들로, 실무 단계에서 관련 데이터 활용도가 높거나, 실제로 콘텐츠 이용자 대상 데이터 생산 경험이 있는 전문가들로 구성되었음

- 전문가 자문은 전체 20명, 총 2회로 구분하여, 1 차 자문은 2021년 3-4월간, 2 차 자문은 5 월 1 달간 진행하였음

- 1 차 전문가 자문은 현재 콘텐츠 이용자를 대상으로 생산되고 있는 다양한 형태 의 데이터들 가운데, 공공영역에서 콘텐츠 이용자 조사를 개발할 필요성과 차별 성을 중심으로 의견을 수렴하고자 하였음

- 2 차 전문가 자문은 1 차 전문가 자문이 완료될 시점에 그 주요 결과를 반영한 1 차 조사안을 참고자료로 제시하고, 조사 방법론과 내용 측면에 대한 구체적인 의견을 수집하였음 
〈표 4-1〉 자문위원 목록

\begin{tabular}{c|c|c|c}
\hline \multicolumn{2}{|c|}{ 1차 면접자문(2021년 3-4월) } & \multicolumn{2}{c}{ 2차 서면자문(2021년 5월) } \\
\hline 연구자문위원 & 직위·분야 & 연구자문위원 & 직위· 분야 \\
\hline 1 & 조사회사 팀장 & $\mathrm{A}$ & 대학교수(빅데이터) \\
\hline 2 & 대학교수(통계학) & $\mathrm{B}$ & 대학교수(애니메이션학) \\
\hline 3 & 대학교수(사회학) & $\mathrm{C}$ & 대학교수(경영학) \\
\hline 4 & 기업데이터센터장 & $\mathrm{D}$ & 대학교수(통계학) \\
\hline 5 & 기업데이터랩 위원 & $\mathrm{E}$ & 대학교수(통계학) \\
\hline 6 & 조사회사 부장 & $\mathrm{F}$ & 문화분야 진흥원 통계센터주임 \\
\hline 7 & 조사회사 부장 & $\mathrm{G}$ & 콘텐츠 공기업 연구위원 \\
\hline 8 & 문화분야 공공기관 전문위원 & $\mathrm{H}$ & 조사회사 부장 \\
\hline 9 & 콘텐츠기업 연구원 & $\mathrm{I}$ & 조사회사 이사 \\
\hline 10 & 빅데이터분석 컨설턴트 & $\mathrm{J}$ & 조사회사 과장 \\
\hline
\end{tabular}

- 2차에 걸친 전문가 자문시, 공통적으로 향후 콘텐츠 이용자 조사에 적합한 내용 및 구조적 설계에 대한 의견을 구하고자 하였음

〈표 4-2〉 자문 구조

\begin{tabular}{|c|c|c|}
\hline \multicolumn{3}{|r|}{ 1차 전문가 면접자문 주요 내용 } \\
\hline $\begin{array}{c}\text { 콘텐츠 이용자 } \\
\text { 조사 필요성과 방법 }\end{array}$ & \multicolumn{2}{|c|}{$\begin{array}{l}\text { - 콘텐츠 이용자 데이터 개발을 위한 방향성과 트렌드 검토 } \\
\text { - 분류체계, 조사방법, 자료 구조 중심의 전반적인 의견 }\end{array}$} \\
\hline $\begin{array}{l}\text { 콘텐츠 이용자 } \\
\text { 조사안 내용 }\end{array}$ & \multicolumn{2}{|c|}{ - 다양한 콘텐츠 이용자 데이터들과의 차별성 획득 방안 } \\
\hline \multicolumn{3}{|r|}{ 2차 전문가 서면자문 주요 내용 } \\
\hline \multirow{4}{*}{$\begin{array}{l}\text { 콘텐츠 이용자 } \\
\text { 조사 방법 }\end{array}$} & 분류체계 & $\begin{array}{l}\text { - 콘텐츠산업 특수분류체계를 기준으로, 'SNS'를 추가하는 것에 대한 동 } \\
\text { 의여부, 비동의 시 이유 } \\
\text { - 콘텐츠 분류에 별도로 추가할 내용이 있다면 분야와 이유 }\end{array}$ \\
\hline & 조사대상 & $\begin{array}{l}\text { - 조사대상 연령 범위 } \\
\text { - 조사대상 설정의 적절성 범위(콘텐츠 이용자 제한 여부) }\end{array}$ \\
\hline & 조사주기 & - 조사 진행 주기 \\
\hline & 조사방법 & - 조사방법에 대한 의견, 고려사항 \\
\hline $\begin{array}{l}\text { 콘텐츠 이용자 } \\
\text { 조사안 내용 }\end{array}$ & \multicolumn{2}{|c|}{$\begin{array}{l}\text { - 조사 내용에 수정 또는 추가가 필요하다고 생각하는 내용 } \\
\text { - 조사에 포함할만한 가치가 있다고 생각하는 정책 관련 내용 }\end{array}$} \\
\hline
\end{tabular}




\section{제2절 분석 결과}

\section{1. 콘텐츠 이용자 조사의 필요성}

- 현재 공공, 민간영역에서 콘텐츠 이용자를 대상으로 다양한 형태의 데이터가 생산 되고 있으나, 전문가들은 콘텐츠 이용양상을 종합적으로 파악하고 분석할 수 있는 데이터의 필요성에 대해서는 모두 동의하였음

- 콘텐츠 분야에서는 일부 민간 기업을 제외하면 활용 가능한 데이터 자체가 절대 적으로 부족한 상황이고, 이제는 콘텐츠 생산자 측면에도 이용자에 대한 심층 분석 결과를 제공해야 한다는 이유가 대다수였음

- 또한 대표성을 갖춘 '조사통계’가 중심 데이터로서 역할을 수행할 필요가 있다는 의견이었음

- 민간 기업이 보유한 이용자 데이터는 개인정보보호법 뿐만 아니라, 정보 접근성 의 한계도 크기 때문에, 기술적인 이용양상에 대한 보고를 넘어, 콘텐츠 이용자 들의 인식이나 가치관 등을 축적할 수 있는 자료가 필요하다는 것임

공공은 콘텐츠 이용자 데이터 자체가 절대 부족한데, 이제는 이용자 정보를 잘 활용해서 생산자측 에 고급 정보를 줄 수 있어야 한다. (8)

기업 이용자 데이터는 개인정보보호법 제약이 생각보다 크다. 국적(내국인, 외국인) 구분이 안되거 나, 성, 연령 정보가 없는 경우도 의외로 많다. 정보 접근성 자체도 문제고... 조사통계로 이용행태 와 선호도, 개인 성향에 대한 정보 수집 노력이 필요하다. (9) 


\section{2. 콘텐츠산업 특수분류체계 기반의 정보 수집}

- 현재 콘텐츠 이용자를 대상으로 한 많은 데이터들이 자체적인 분류체계를 설정하 고 있어, 콘텐츠 이용자 조사 개발 시에는 콘텐츠산업 특수분류체계를 최대한 유 지, 활용하는 것으로 차별성을 확보해야 한다는 제언이 많았음

- 이는 콘텐츠 장르의 분류 기준과 범위가 다양한 서로 다른 종류의 데이터들을 아우를 수 있는 기준으로 적합하다는 이유 때문임

기존 분류체계를 최대한 유지하는 것이 혼란을 일으키지 않을 것이다. (F)

통계법상 콘텐츠산업 특수분류체계가 변하지 않는 이상, 먼저 분류체계를 조정하면 나중에 문제가 복잡해질 수 있다. 파일럿 조사를 몇 년 해보고 결정하는게 좋다. (10)

콘텐츠쪽은 사실 신문, 방송, $\mathrm{PC}$, 모바일까지, 특히 방송 중심으로 데이터가 발전해서 최근에는 채널별, 프로그램별 측정치도 하루단위로 축적된다. 그렇다면 국가통계는 더 큰 그림을 제공해주는 것이 바람직하다. 분류체계를 흔들지 말고, 이용행태 파악이 복잡하다는 점을 간과할 수 없다. (7)

- 1 차 전문가 자문과정에서, 분류체계에 대한 전문가 이견은 첫째, '텍스트 콘텐츠의 이용', 즉 교육, 정보 활동에 대한 분류를 분리해야 할 것인지, 둘째, 콘텐츠 생산 과 소비가 확장되고 있는 'SNS'를 별도로 구분할 것인지를 중심으로 나타났으나, 결과적으로 현재 콘텐츠산업 특수분류체계를 큰 틀에서 유지하는 방안이 추천됨 - 뉴스, 교육 등 정보 탐색 활동에 대한 측정은 콘텐츠 이용자의 주관적 판단에 따라 결과로 측정될 가능성이 높고, SNS는 별도 조사로서도 분리하는 것이 더 적합할만큼 규모가 크다는 이유임

- 2차 전문가 자문시에는 콘텐츠 이용자 관점에서 실질적인 콘텐츠 이용의 범위를 고려하여, 콘텐츠산업 특수분류체계를 기준으로 이용이 활발한 8개 분야(광고, 지 식정보, 콘텐츠솔루션, 공연 4개 분류 제외), 그리고 SNS 분류를 별도로 추가하는 것에 대한 의견을 재검토하였으나, 마찬가지로 SNS를 콘텐츠 분류로 포함하는 것 에는 전문가들 대부분이 동의하지 않았음

- SNS를 기존의 콘텐츠와 동등선상에서 볼 수 있는지에 대해서는 더 전문적인 논의가 필요하며, 아직까지 SNS는 콘텐츠의 이용 경로로 처리하거나, 별도의 부가조사로 분리하는 것이 더 적합하다는 의견임 
SNS로 영화, 음악, 만화, 많은 콘텐츠들을 다 만들수도 이용할수도 있지만, 그 자체로 큰 분야여서 별도의 부가조사 형태로 분리하는 것이 적절하다. (I)

SNS 이용행태나 특성, 영향력 같은 의미있는 연구를 위해서는 더 다양한 자료를 활용해야 하고, 조사통계만의 유의미한 결과를 도출하기 어렵다. (C)

- 한편, 그동안 콘텐츠 분야의 조사들이 상대적으로 관심을 덜 가져온 오프라인 전시 나 공연을 콘텐츠 범주 내로 포함해야 할 필요가 높다는 의견들이 있었음

- 공연은 특히 코로나 이후 오프라인에서 온라인화가 활성화되고 있기 때문임

장기적으로는 공연과 전시 분야도 포함되어야 한다. 영화, 영상과 유사한 성격인데, 콘텐츠 이용자 조사에서는 자주 누락되는 것 같다. $(\mathrm{H})$

코로나 이후 온라인 공연이 양적으로든 질적으로 많이 변화하고 있으니, 장기적으로 이용자 변화를 계속 파악할 필요가 있다. (J)

기존 조사들이 공연을 누락한 점이 아쉽다. 별도로 공연 분류를 추가하고, 이 부분에 대해 온, 오프 라인 이용경험을 구분할 필요가 높다. (B)

- 또한 콘텐츠 이용행동 분류는 너무 세밀한 범주를 지양해야 한다는 의견이 많았음

콘텐츠 산업 변화속도가 빠르다는 점을 고려해서, 행동분류는 너무 세밀하게 하지 말고, 출발은 보 수적으로 설계해야 한다. 행태를 너무 세세하게 분류하면 나중에 데이터 관리가 힘들어질 수 있다. 기준은 특수분류체계로 하되, 너무 세세한 분류는 측정에 별로 도움이 안된다. (2)

이용행동 범주를 너무 세세하게 나누면 오히려 편향성 문제가 생긴다. (3)

이용행태는 기업 내부 서비스별 로그데이터를 따라가기 힘들다. 팟캐스트나 오디오북이 방송이나 출판이 아니라, 이용자 관점에서는 음원이다. (9) 


\section{3. 조사대상 범위의 확대}

- 콘텐츠 이용자 대상 조사대상은 고령화된 인구구성을 고려하여 최고 연령을 제한 하지 말고, '전국민 대상 무작위 추출' 방법을 초기 조사에 적용하여 조사대상의 규모와 범위를 확대하는 것이 적합하다는 의견이 많았음

- 유아-아동 및 초등학생을 포함할 경우에는 별도 조사로 분리하는 것이 좋다는 의견이 많았음

우리나라 고령화로, 65 세 이상 인구 비중이 이미 많이 늘었다. 고연령대 제한은 필요없다고 본다. (B)

65세 이상도 새로운 콘텐츠 이용자로 떠오르고 있는 상황이므로, 최고연령 한도를 제한하지 말아야 한다. 연령은 자기기입식으로 수집할 것 $(\mathrm{G})$

초등학생 이하는 부모 입회 하의 조사나, 별도 부모조사가 필요하다. 콘텐츠 장르 개념을 이해시키 기도 어려울뿐더러, 솔직한 응답을 기대하기 어렵다. (I)

응답의 정확성을 고려해, 시작점은 중학생 이상이 적절하다. $(F)$

- 응답자 범위로는 현실적으로 1 개 이상의 콘텐츠를 전혀 사용하지 않는 집단이나, 특정 콘텐츠만 이용하는 집단(마니아 집단) 등에 대한 파악이 되어있지 않으므로, 초기 표본설계는 '전국민 인구를 대상으로 무작위 표본추출'을 하는 것이 적절하다 는 의견이 많았음

자료의 충실성 및 활용도 제고를 위해서는 콘텐츠 이용자만 조사하는 것이 타당하다. 하지만 현실 적으로 콘텐츠를 1 개도 이용하지 않는 사람이 있다고 해도 비중이 낮을 것이어서, 이용자 프로파일 에 기반한 표본할당을 향후에 보완하고, 대표성을 갖는 통계수치 산출이 가능하도록 해야한다. $(\mathrm{H})$

일단 최대 다수의 응답자를 무작위로 추출해서 초기 조사를 진행해보고, 향후 표본추출 방식과 규 모를 조사 방법론 차원에서 대응해야 한다. (I)

통합조사는 가능한 한 간단하게 설계해서, 점점 볼륨을 키워야 한다. 초기에는 표본규모를 최대한 키워서 무작위 표본추출을 하고, 통계보정단계에서 대표성을 확보하는 방향으로 가야 한다. (2) 


\section{4. 예산과 인력을 고려한 조사주기 설정}

- 조사주기에 대해서는 현실적으로 조사에 투입할 수 있는 예산과 인력, 조사의 목적 을 고려해야할 필요성이 높지만, 그럼에도 불구하고 조사의 진행은 1 년 주기가 가 장 적당하다는 의견이 많았음

예산과 인력 등을 고려하면, 1년에 1회 정도가 적절하다. (C)

일반 국민들의 콘텐츠 이용행태는 관습적인 측면이 있고, 단기간에 변화할 것으로 예상되지 않아 1년 주기가 타당하다. (D)

1년 주기가 안정적이라고 본다. 콘텐츠가 매일 많이 이용하는 필수 소비재 정도기 때문에, 응답자 의 인지부조화가 많이 발생하지는 않는 편이다. (1)

- 이와 대조적으로, 콘텐츠 생산 및 유통 주기가 짧고, 콘텐츠 이용패턴을 축적한 자료가 부족하다는 이유에서, 반기별(1년 2회), 또는 분기별(1년 4회) 조사가 필요 하다는 의견들도 있었음

- 이는 실제로 동일 콘텐츠 분야에서도 1 년간 수차례 트렌드가 변화하는 현실을 고려한 의견으로 볼 수 있음

드라마는 2 3개월이면 끝나고, 영화도 2 3개월 정도면 극장상영이 끝나는 경우가 많다. 연간 단위 조사는 결과가 나올 때쯤 이미 시장 상황이 크게 바뀐 뒤라, 조사횟수를 늘리는게 필요하지만, 아니 면 별도 조사로 표본추출과정을 간소화한 자료도 방법이 될 수 있다. (I)

예산 등 현실성을 고려하면 연 1회가 적당하지만, 특이성을 포착할 필요가 있다면 연 2-3회도 좋 다. $(\mathrm{H})$ 


\section{5. 혼합조사방법론 적용}

- 조사 방법으로는 PC와 모바일을 병행하는 조사가 적절하다는 의견이 가장 많았음. 이어 대면조사와 온라인조사를 병행하는 것이 적절하다는 의견도 많았음

- 이는 조사대상의 다양한 연령대, 특히 조사 과정에 안내가 필요한 아동, 청소년 및 노년층을 고려한 결과로 볼 수 있음

- 한편, 모바일, 온라인 중심의 조사방법이 온라인 편향적 표본을 구성할 가능성 을 염려한 결과로도 볼 수 있음

10세 14세층이 포함되면, 대면조사를 병행할 필요는 있다. $(H)$

어르신조사의 경우 대면조사를 병행하는 혼합방식을 추천한다. (D)

$\mathrm{PC}+$ 모바일 조사는 패널사 보유 패널 대상이어서 대표성에 대한 문제제기가 있을 수 있다. 아무래 도 온라인 친화적인 사람들이 주로 참여해서 온라인 편향적인 결과가 나올 수 있다. 대신 표본규모 를 많이 늘려 보정 가능성을 확보하는 것이 좋다. (I)

- 한편, 조사예산이 허락된다면, 콘텐츠 다이어리 조사로 차별성을 확보할 수 있다는 의견들도 많았음

예산이 허락한다는 전제하에 패널, 다이어리 조사를 고려해볼 수 있다. 조사대상을 고정함으로써 시간의 흐름, 정부정책 등에 따른 이용행태 변화를 깊이 있게 살피는 일이 가능하기 때문이다. $(\mathrm{G})$

예산이 허락된다면 콘텐츠 다이어리 방식으로, 콘텐츠 이용의 질적 변화 등에 대해 보다 깊이 있고 입체적인 결과를 얻을 수 있을 것이다. $(\mathrm{G})$

모바일로도 다이어리 조사가 가능하다. 다만 예산과 통계 보정 역량이 관건이다. (1)

유사 조사들이 보통 2-3일치 다이어리 평균치를 활용하는데, 콘텐츠 생산 주기상 1주일(7일) 다이 어리 조사로도 차별성을 갖는다. (4)

표본조사는 표본의 대표성이 매우 중요해, 대표성 없이 표본규모만 늘리면 왜곡된 결과를 얻을 위 험성이 높다. 이에 많은 예산과 인력이 필요하며, 어떤 방법이든 표본규모가 클 경우 어려움이 많 다. (E) 


\section{6. 인식 정보 수집의 가치}

- 조사 내용의 구성에 있어서는 콘텐츠 이용자들의 이용행태와 인식 간의 정보를 중 점적으로 수집하도록 구성하는 것이 좋다는 의견이 많았음

이용자들의 이용행태와 인식 중심의 조사는 정책개발 측면에도 도움이 될 것이다. 이러한 부분이

기업 데이터와 구별되는 확실한 차별성이다. (A)

종합적이고 정례적인 조사는 매우 필요하지만, 시간, 인식, 삶의 질 같은 고급정보 제공도 중요하 다. 지출, 구매 관련 정보는 상대적으로 많은 편이기도 하고, 보정 방법도 많다. (E)

콘텐츠 이용 만족도를 일반적인 삶의 질 측정과 분리하여, 압축적으로 수집할 필요가 있다. 조사항 목을 가능한 한 축소해야 한다. (E)

- 인식 정보 수집 측면에서는 정책 관련 내용도 포함될 수 있음

- 현재 콘텐츠 이용자를 대상으로 한 저작권 관련 질문은 응답자 관점에서 어려울 수 있고, 최근 코로나와 같은 거시적인 변화는 장기적으로 지속될 수 있기 때문 에 정책적 관심이 필요하다는 의견이 확인되었음

저작권 관련 질문들은 공급자 관점이지, 실제로 이용자들이 본인이 소비한 콘텐츠가 불법인지 모른채 이용한 것을 측정할 방법은 요원하다. 정책 관련 내용들은 그래서 체계적인 검토가 요구된다. (5)

코로나 19 이후 콘텐츠 시장 규모가 커졌어도, 콘텐츠별로는 하락한 분야도 다양하게 존재하고 있 다. 이것이 장기적으로 어느 정도 영향을 미칠지 꾸준히 소비를 예측할 수 있도록 해야한다. (B)

COVID19로 맞벌이 가정 아동의 학습 및 오락 관련 콘텐츠 이용량 증가가 예상되는데, 이 추이가 어떻게 변화할지 검토가 필요하다. (중략) 어르신(65세 이상)들의 콘텐츠(특히 유튜브) 이용확대에 대한 파악 또한 필요하다. (D)

- 또한 문화체육관광부 차원에서 콘텐츠 이용자 층위의 정책 의견을 폭넓게 수집하 는 것이 필요하다는 의견도 있었음

문화체육관광부 차원에서 이용자 정책에 대한 의견을 폭넓게 물을 수 있다. 가령 공연시설 소비할 인권 및 통합문화이용권 지원, 온라인 공연장 조성, 문화예술 치유 프로그램 제공, 또는 콘텐츠 기 업들의 이용자 정보활용에 대한 보호정책의 개발이라든가 $(\mathrm{G})$

WHO 국제질병표준분류기준에서 게임중독을 질병으로 보고 질병코드를 부여하기로 했는데, 이에 대한 국민들의 인식 검토도 필요하다. $(\mathrm{H})$

도서나 공연 신용카드 사용분에 대한 소득공제 정책이나, 문화과학바우처 제도라든가, 정책 점검을 위한 의견을 계속 수집해야할 필요성이 높다. (I)

코로나 이전에도 움직임이 있었지만, 이후에는 온라인 청소년 범죄 관련해서 기업들이 움직임을 면밀 하게 분석하고 있다. 혹은 온라인 공연 부분들도 조사통계로 좀 더 세밀하게 파악하면 좋겠다. (5) 

콘텐츠 이용자 데이터 개발 기반연구

\section{제5장}

결론 



\section{제1절 콘텐츠 이용자 데이터 구축의 방향성}

\section{1. 콘텐츠 이용자 데이터 개발 방안}

- 본 연구는 우리나라 콘텐츠 산업이 세계적인 성장과 변화를 주도하는 최전선에 있 고, 콘텐츠 생산과 소비 간의 상호영향 관계가 더욱 밀접해진 현실에서, 산업적 영 향력이 증대한 콘텐츠 이용자에 대한 체계적인 분석을 위해 콘텐츠 이용자 데이터 개발의 필요성을 제기함

- 콘텐츠 이용자는 역사적으로 여가활용의 주체, 또는 미디어 기기와 기술발전에 따 른 적극적 수용자 등 다양한 관점에서 다뤄져왔지만, 콘텐츠와 콘텐츠 산업에 대한 국제적인 정의와 범주가 뚜렷하게 합의된 바가 없듯, 각 사회문화적 환경과 맥락에 따라 다양한 방법으로 연구되어 왔음

- 현재 콘텐츠 산업계에서는 이용자 층위에서 다양한 데이터가 생산되고 있으나, 콘 텐츠에 대한 관점이 서로 다름으로 인해, 매우 다양한 방법으로 범주를 설정함으로 써 자료 간 상대 비교가 어려운 편임

- 또한, 콘텐츠 이용자를 대상으로 축적된 데이터들은 콘텐츠 산업 현장에서는 수익 증대에 직결될 정도로 가치가 상승하였으나, 콘텐츠 이용자들의 이용양상을 검토 할 수 있는 데이터에 대한 접근성은 매우 제한적임

- 우리나라 콘텐츠 산업 생태계를 구성하는 약 $90 \%$ 의 사업체가 소규모이고, 이러 한 이용자 데이터의 보유와 활용 역량을 갖춘 기업이 극히 일부로 한정되어 있 다는 점에서 콘텐츠 산업계의 동반 성장을 위해서도 해결 방안이 필요함

- 본 연구에서 살펴보았듯, 콘텐츠 이용자 대상의 데이터는 조사통계 자료 중심의 정형데이터, 로그데이터, 빅데이터에 이르기까지 매우 다양함 
〈표 5-1〉 콘텐츠 이용자 데이터 현황 및 특성 분석결과

\begin{tabular}{|c|c|c|c|}
\hline 구분 & 조사통계 & 로그데이터 & 빅데이터 \\
\hline 형태 & - 정형데이터 & - 반정형데이터 & - 비정형데이터 \\
\hline 장점 & $\begin{array}{l}\text { - 대표성(국가승인통계) } \\
\text { - 편의성(실태조사 등) }\end{array}$ & $\begin{array}{l}\text { - 정밀 분석이 가능한 정보 } \\
\text { 수집 }\end{array}$ & $\begin{array}{l}\text { - 시의성 } \\
\text { - 저비용 }\end{array}$ \\
\hline 단점 & $\begin{array}{l}\text { - 이용행태 파악에 제한점 있음 } \\
\text { (비용, 전문성 필요) }\end{array}$ & - 정보 접근성 & - 대표성이나 정확성 취약 \\
\hline 비용 & $\begin{array}{l}\text { - 표본 대표성이 확보될수록 고 } \\
\text { 비용 }\end{array}$ & - 고비용 & - 상대적으로 저렴 \\
\hline $\begin{array}{l}\text { 작성 소요 } \\
\text { 시간 }\end{array}$ & - 예산, 방법론에 따라 차이 & - 매우 신속 & - 보통 \\
\hline $\begin{array}{l}\text { 주요 활용 } \\
\text { 목적 }\end{array}$ & $\begin{array}{l}\text { - 정보의 지속적인 축적 } \\
\text { - 체계적인 분석 }\end{array}$ & $\begin{array}{l}\text { - 시의적인 기술통계치 } \\
\text { 파악 }\end{array}$ & $\begin{array}{l}\text { - 이용행태 및 상호작용 분석 } \\
\text { - 기업 수익 증대 및 마케팅 } \\
\text { 목적 }\end{array}$ \\
\hline
\end{tabular}

- 공공 영역에서는 현재 주로 조사통계 자료가 생산되고 있으나, 콘텐츠 이용자를 대상으로 한 조사의 절대량 자체가 매우 부족한 상황임

- 표본 대표성이 확보된 국가승인통계 자료들 또한, 콘텐츠 이용 범주를 설정하는 방법이 매우 다양하거나 누락된 장르가 있어, 콘텐츠 이용양상을 체계적으로 파 악하기에는 명확한 한계가 있음

- 콘텐츠 각 장르별로 비교적 지속적으로 생산되어온 주요 실태조사들 또한, 아래 표에서 확인할 수 있듯이 특정 장르에 대한 이용 정보를 파악할 수 있을 뿐, 이 용자 측면에서 다양한 콘텐츠 장르를 융·복합적으로 동시 이용하는 양상을 종 합적으로 파악할 수 있는 가능성은 결여돼 있음

- 우선, 콘텐츠 이용자 관점에서 실질적으로 콘텐츠를 이용했다고 판단하기 어려 운 광고, 지식정보, 콘텐츠솔루션 분야를 제외하더라도, 성별, 연령별, 지역별 이용양상을 파악할 수 있는 가능성도 상당히 제한적임

- 무엇보다 조사별로 이용행태를 측정하는 기준 단위나 내용이 달라, 장르 간 상 호 비교검토가 불가능한 구조임 
〈표 5-2〉 우리나라 사회인구학적 요인별 콘텐츠 이용행태 현황

\begin{tabular}{|c|c|c|c|c|c|c|c|c|c|c|c|c|}
\hline \multirow[b]{2}{*}{ 코드 } & \multirow[b]{2}{*}{ 콘텐츠 분류 } & \multirow[b]{2}{*}{ 이용행태 } & \multicolumn{2}{|c|}{ 성별 } & \multicolumn{6}{|c|}{ 연령별 } & \multicolumn{2}{|c|}{ 지역별 } \\
\hline & & & 남성 & 여성 & 10 대 & 20대 & 30대 & 40대 & 50대 & $\begin{array}{l}60 \text { 대 } \\
\text { 이상 }\end{array}$ & 수도권 & 비수도권 \\
\hline 1 & 출판) & 이용량(ㄱ- & 38.7 & 31.6 & 57.6 & 31.8 & 31.9 & 32.1 & 25.8 & - & - & - \\
\hline 2 & 만화2) & 이용량(이용경험) & 18.4 & 21.5 & 25.2 & 29.0 & 20.6 & 14.0 & 11.0 & - & 23.3 & 18.6 \\
\hline 3 & 음악) & 이용량(0 & 53.3 & 54.2 & 59.2 & 73.0 & 52.4 & 39.9 & 48.0 & - & 54.9 & 52.7 \\
\hline 4 & 게임) & 이용량 & 73.6 & .3 & 91.5 & 85.1 & 74.0 & 76.6 & 56.8 & 35.0 & 69.9 & 71.1 \\
\hline 5 & 영화5) & 이용량(주말이용경험) & 48.0 & 44.3 & 68.1 & 68.1 & 60.4 & 54.8 & 44.4 & 14.9 & - & - \\
\hline 6 & 애니메이션(6) & 이용량(이용경험) & 21.5 & 22.9 & 27.0 & 18.9 & 21.4 & 18.2 & 7.0 & - & 20.9 & 23.0 \\
\hline 7 & 방송ㄱ) & 이용량(주말이용경험) & 52.0 & 51.6 & 24.7 & 29.4 & 46.4 & 58.4 & 60.5 & 61.0 & - & - \\
\hline 8 & 광고 & 이용량 & - & - & - & - & - & - & - & - & - & - \\
\hline 9 & 캐릭터8) & 이용량(이용경험) & 16.9 & 20.5 & 23.3 & 22.8 & 17.0 & 13.8 & 12.9 & - & 19.3 & 17.8 \\
\hline 10 & 지식정보 & 이용량 & - & - & - & - & - & - & - & - & - & - \\
\hline 11 & 콘텐츠솔루션 & 이용량 & - & - & - & - & - & - & - & - & - & - \\
\hline 12 & 공연? & 이용량(이용경험) & 21.9 & 18.2 & 19.5 & 20.5 & 19.6 & 20.1 & 19.1 & 19.7 & - & - \\
\hline
\end{tabular}

자료: 1) 한국콘텐츠진흥원(2020), 2020 웹소설이용자실태조사;

2) 한국콘텐츠진흥원(2020), 2020 만화이용자실태조사;

3) 한국콘텐츠진흥원(2020), 2020 음악이용자실태조사;

4) 한국콘텐츠진흥원(2020), 2020 게임이용자실태조사;

5) 문화체육관광부(2020) 2020 국민문화예술활동조사;

6) 한국콘텐츠진흥원(2020), 2020 애니메이션이용자실태조사;

7) 문화체육관광부(2020) 2020 국민여가활동조사;

8) 한국콘텐츠진흥원(2020), 2020 캐릭터이용자실태조사;

9) 문화체육관광부(2020) 2020 국민문화예술활동조사 재정리

- 로그데이터나 빅데이터는 주로 민간 영역에서 생산되고 있는데, 일반 정보 이용자 의 접근성이 매우 제한적임

- 정보 수집 및 가공 처리 시간과 비용 측면에서는 큰 장점이 있음

- 그러나 조사통계 중심의 정형데이터에 비해, 대표성이 부족하다는 한계가 있음

- 특히 SNS 중심의 메시지 데이터나, 콘텐츠 기업이 내부적으로 보유한 고객 데 이터는 콘텐츠 이용행태를 매우 섬세하게 분석할 수 있는 재료가 될 수 있으나, 데이터에 따라 정보 결함이 있거나, 편향성이 있다는 한계도 있음

- 콘텐츠 이용자 빅데이터의 경우, 일반적으로 정보 접근성이 용이한 SNS 데이터를 활용하는 사례가 가장 대표적이며, 그 외에도 빅데이터 ISP를 세부분야별로 수립 하여, 그동안 잘 활용되지 못했던 공공데이터를 발굴, 체계화하려는 노력이 있음 
- 이러한 현황을 고려할 때, 본 연구에서는 향후 콘텐츠 이용자를 체계적으로 분석할 수 있는 기초적인 데이터 기반을 강화하기 위해, 콘텐츠 이용양상을 종합적으로 수집, 검토, 분석할 수 있는 콘텐츠 이용자 조사 개발을 우선적으로 제안함

\section{2. 콘텐츠 이용자 조사 구축}

- 콘텐츠 이용자 조사는 콘텐츠 이용자 층위에서 생산되고 있는 다양한 데이터들 가 운데, 콘텐츠 이용양상에 대한 심층적인 자료의 축적과 분석과 특히 장르 간 상호 비교가 가능한 자료를 구축하기 위해 필요함

- 최근 일반 조사환경에 있어, 사람들의 다양한 기기 사용증가, 응답자의 부담, 1 인 가구의 증가로 인한 전통적인 대면조사의 어려움, 온라인 조사 과정에서 발 생하는 특수한 어려움 등 급격한 변화에 대응하기 위한 조사방법론 차원에서의 연구와 논의가 활발한만큼, 콘텐츠 이용자를 대상으로 한 조사통계의 대표성 확 보를 위한 자료수집의 방법, 표본추출이나 통계적 보정 등을 방법론 측면에서의 검토를 앞서 진행하였음

- 본 연구에서 콘텐츠 이용자를 대상으로 생산된 주요 조사통계 자료들의 표본설계 방법을 각 자료별로 검토한 결과, 대부분 1 년 주기의 통계청 인구통계 기반의 확률 표집 횡단형 조사로 진행되어 왔음을 파악함

- 횡단 조사는 주로 조사할 대상이 많고, 조사대상자들의 특성이 다양할 때 실시 하며, 특정 시점에 연간 1 회 조사로 진행함. 이상적인 횡단 조사는 다양한 조사 집단별로 인구비례할당법에 기반하여 많은 수의 응답자들을 표집하는 것으로, 이에 따르면 표본 규모가 클수록 안정적인 결과를 확보하기 유리함

- 따라서 횡단 조사의 모집단은 다양한 인구집단이거나, 특수성이 있는 대상으로 설정되기 때문에, 각 집단을 대표할 수 있는 충분한 수의 표본을 확보해야 조사 의 신뢰성과 타당성이 확보됨. 즉 조사규모와도 긴밀한 관계가 있음

- 이와 비교하여, 종단 조사는 시간의 흐름에 따라 조사대상의 변화를 측정하는 것이 주요 목적이라는 점에서 횡단 조사와 목적과 구조가 다름. 종단적 접근에 
서 중요한 점은 시간의 흐름에 따른 조사대상의 변화를 측정하는 것이어서, 동 일한 조사대상에 대해, 일정한 기간 간격을 두고 조사를 수차례 반복해야 함

- 횡단 조사와 비교하여 종단 조사는 소요되는 시간과 예산, 인력 등 모든 측면에 서 더 많은 투자가 필요함. 추적조사를 위해 응답자들과 계속 연락을 취할 수 있어야 하고, 동의도 구해야 하며, 주거이동을 하거나 분가를 한 경우에는 방문 조사 등 범위가 더 넓어지며, 특히 조사 이탈층에 대한 표본 보정에 이르기까지 훨씬 많은 비용과 노력이 요구됨. 그럼에도 불구하고, 장기적으로 발굴해낼 수 있는 메시지의 힘이 크기 때문에 가치가 높음

〈표 5-3〉 조사통계 자료배열 구조

\begin{tabular}{|c|c|c|}
\hline 구분 & 횡단 조사 & 종단 조사 \\
\hline 조사 목적 & $\begin{array}{c}\text { 특정 조사 시점의 } \\
\text { 표본과 모집단 특성 파악 }\end{array}$ & $\begin{array}{c}\text { 시간의 흐름에 따른 } \\
\text { 표본과 모집단 특성의 변화 조사 }\end{array}$ \\
\hline 표본 규모 & $\begin{array}{l}\text { 응답자들을 인구사회학적인 특성에 따라 } \\
\text { 분류하기 때문에 표본규모가 클수록 좋음 }\end{array}$ & $\begin{array}{c}\text { 추적조사를 해야하므로 } \\
\text { 상대적으로 표본규모가 작은 편임 }\end{array}$ \\
\hline 측정 횟수 & 1회 & $\mathrm{n}$ 회 \\
\hline 세부 종류 & 표본의 구성과 설계방법에 따라 다양 & $\begin{array}{l}\text { - 트렌드조사: 동일한 조사문항에 대해 시차를 } \\
\text { 두고 조사를 반복하나, 매회 응답자가 다름 } \\
\text { - 코호트조사: 동일한 조사문항에 대해 시차를 } \\
\text { 두고 조사를 반복하나, 매회 응답자들과 세 } \\
\text { 대(출생연도)가 같음 } \\
\text { - 패널조사: 매회 응답자가 같음 }\end{array}$ \\
\hline 비용 & 다양(종단 조사에 비해 저렴) & 높음 \\
\hline
\end{tabular}

- 기존의 콘텐츠 이용자 대상 조사들이 대부분 횡단 조사로 작성된 이유는 이처럼 예산과 인력 투입에 대한 부담감이 때문이기도 함. 또한, 콘텐츠 산업 트렌드 변화 가 바른 편이어서, 1 년을 주기로 설정하더라도 트렌드 변화를 측정하기 위해서는 조사 횟수를 늘리는 것이 필요한데, 이 또한 마찬가지로 측정 전후 단계에 소요되 는 예산이 우선적으로 확보되어야 함

- 콘텐츠 이용자 조사를 향후 국가승인통계로 작성할 목적과 의향이 있다면, 무엇보 다 표본의 대표성 확보를 위해, 조사 목표모집단을 '전국민 인구'로 설정하고, 통계 청 센서스 자료에 기반한 확률표집 방법론의 적용이 필수적임 
〈표 5-4〉 콘텐츠 이용자 주요 조사통계 현황

\begin{tabular}{|c|c|c|}
\hline 구분 & 국가승인통계 & 주요 실태조사(비승인통계) \\
\hline 목표모집단 & - 일반 국민 & - 특정 콘텐츠 이용자 \\
\hline 표집틀(조사모집단) & - 인구(주택)총조사(등록센서스) & - 조사기관(또는 회사) 자체 보유 명부 \\
\hline 표본추출방법 & - 확률표집 & - 비확률표집 \\
\hline 자료수집방법 & - 면접조사 & - 면접조사+온라인조사 등 혼합조사방법론 \\
\hline 대표성 & $\begin{array}{l}\text { - 대표성 확보 } \\
\text { - 예산 및 인력 확보 }\end{array}$ & $\begin{array}{l}\text { - 표집틀 보완 } \\
\text { - 표본규모를 확대함으로써 통계적 보정을 통 } \\
\text { 해 대표성 확보 }\end{array}$ \\
\hline 자료배열 & - 횡단형(일부 종단형) & - 횡단형 \\
\hline
\end{tabular}

- 현재 국내 공공영역에서 콘텐츠 이용자를 대상으로 종합적으로 실시하는 조사가 없는 상황이기 때문에, 콘텐츠 이용자 영역의 중심데이터로 역할을 수행할 통합조 사를 중심으로 향후 별도의 장르별 특화 부가조사 개발 가능성까지를 염두한다면, 시범조사를 초기 몇 년간 시행하여 자료 구조를 개선해가는 것도 방법이 될 수 있음 - 초기 시범조사 표본을 비확률표집 방법으로 추출한다면, 가능한 한 인구비례할 당 표본규모를 확대하고, 확률표집이 가진 표본조사의 대표성이라는 장점을 확 보하려는 통계적 보정 노력이 요구됨

- 이때 대표적인 통계 보정 방법으로, 갈퀴법(raking ratio)을 활용할 수 있음. 갈퀴법은 추출한 표본에 모집단의 특성을 이용해 가중치를 적용하는 사후보정 기법임. 주요 원리는 범주형 자료에서 주변분포(marginal distribution)만 알 고 결합분포(joint distribution)를 모를 때, 주변합(marginal total) 값을 사용 해서 미지의 결합분포 가중치를 추정하는 것으로, 아래 표와 같은 비확률표본에 서, 실제 모집단에 대해서는 전체값(Total)에 근사치만 확보했을 뿐, 세부 정보 를 정확히 모를 경우, 각 행렬의 총합값 정보와 가중치를 활용하여 표본과 모집 단 간의 불일치 정도를 반복적으로 줄여가는 방식임 
〈표 5-5〉 갈퀴법 통계보정 사례

\begin{tabular}{c|c|c|c|c|c|c}
\hline & 서울 & 부산 & 인천 & 대구 & 대전 & 전체(Total) \\
\hline 대기업 & 300 & 1200 & 60 & 30 & 30 & $(1620)$ \\
\hline 중소기업 & 150 & 1080 & 90 & 30 & 30 & $(1380)$ \\
\hline 전체(Total) & $(450)$ & $(2280)$ & $(150)$ & $(60)$ & $(60)$ & $(3000)$ \\
\hline
\end{tabular}

- 조사통계의 최대 강점이 대표성에 있고, 특히 콘텐츠 분야에서 최근 다양한 종류의 이용자 데이터 흔적(data trace)를 활용한 빅데이터의 활용도 활발한 추세에 있다 는 점을 고려하면, 콘텐츠 이용자 조사는 가능한 한 표본의 대표성과 내용 측면에 서 차별성을 갖출 필요성이 높음

- 한편, 콘텐츠 이용자 조사대상의 연령 범위는 우리나라 인구구조가 전반적으로 고 령화된 점을 고려하여, 연령 상한에 제한을 두지 말고 고령층을 최대한 포함해야 할 필요성이 높다는 연구 자문 결과를 참고할 가치도 높음

- 다음은 조사에 필수적인 예산의 다양한 가능성을 고려한 조사안 제시 결과임

\section{가. 대표성을 갖춘 조사통계 개발}

- 대표성을 갖춘 콘텐츠 이용자 조사를 구축하기 위해서는 무엇보다 일반 사회 인구 구성을 반영한 표본설계가 중요함

- 이는 국가승인통계를 목적으로 한 것이므로, 주무부처의 의지와 협조가 요구됨

- 저연령대의 경우, 콘텐츠 이용행태와 관련 정보에 대한 응답이 어려울 수 있으 므로, 시작 연령대는 만 10세(초등학생) 이상으로 설정하고 상한 연령대에 제한 을 두지 않는 방법으로 가능한 한 많은 표본이 표집될 수 있도록 함

- 조사통계 대표성 확보를 위해 표집틀은 통계청 인구주택총조사 명부를 활용하 며, 안정적인 자료 수집과 처리를 위해 대면 면접조사로 진행함

- 자료배열 구조는 트렌드 및 정책 점검을 위해 횡단형으로 진행하되, 예산이 확 보될 경우 보다 심층적인 분석을 위해 종단형 콘텐츠 이용 시간일지를 포함함 
〈표 5-6〉대표성을 갖춘 콘텐츠 이용자 조사 개발안

\begin{tabular}{|c|c|c|}
\hline 구분 & 표본 설계 & 특이 사항 \\
\hline 목표모집단 & \multicolumn{2}{|l|}{ - 전국 가구 및 만 10 세 이상 일반 국민 } \\
\hline 조사모집단 & \multicolumn{2}{|c|}{ - 현재 전국 가구 및 가구내 상주하는 만 10세 이상 가구원 } \\
\hline 표집틀(추출틀) & \multicolumn{2}{|l|}{ - 인구(주택)총조사(등록센서스) } \\
\hline 표본추출방법 & \multicolumn{2}{|l|}{ - 확률표집 } \\
\hline 자료수집방법 & - 면접조사 & - 만 10-15세(초등학생) 부모조사 분리 \\
\hline 자료배열 & - 횡단형 연간 정례조사 및 시간일지 & • 종단형(예산 확보시) \\
\hline
\end{tabular}

\section{나. 시의성을 갖춘 조사통계 개발}

- 시의성을 갖춘 콘텐츠 이용자 조사를 구축할 수 있는 이유는 콘텐츠 이용 트렌드 변화 속도가 빨라, 이를 계절별, 또는 반기별로 파악하여, 시장의 민감성이나 이용 자의 관습적인 이용행태의 변화 정보를 파악하기 위함임

- 따라서 국가승인통계를 목적으로 한 조사통계와 비교할 때, 대표성은 비교적 결 여될 수 있으나, 무작위 표본 추출을 통해 표본규모를 확대할 수 있다면, 통계 보정을 통해 대표성을 비교적 확보할 수는 있음

- 표집틀은 조사회사가 보유한 패널을 활용하되, 조사방법론은 콘텐츠 특성을 고 려한 모바일 조사, 또는 혼합방법론을 적용할 수 있음. 본 연구의 전문가 자문의 견 수렴결과에서도 콘텐츠 응답자를 접촉하는 방법으로 PC와 모바일을 중심으 로 한 혼합조사방법론이 적절하다는 의견이 가장 많았는데, 이는 조사에 소요되 는 시간과 비용 측면에서 매우 효율적임

〈표 5-7〉 시의성을 갖춘 콘텐츠 이용자 조사 개발안

\begin{tabular}{c|l|c}
\hline 구분 & \multicolumn{1}{|c|}{ 표본 설계 } & 특이 사항 \\
\hline 목표모집단 & - 전국 만 10세 이상 일반 국민 \\
\hline 조사모집단 & - 만 10세 이상 일반 국민 \\
\hline 표집틀(추출틀) & $\bullet$ 조사회사 보유 패널 \\
\hline 표본추출방법 & - 성, 연령, 지역별 비례할당 \\
\hline 자료수집방법 & - 모바일 조사 또는 혼합방법론 \\
\hline 자료배열 & - 횡단형 설문조사 & - 분기별, 반기별(예산 확보시) \\
\hline
\end{tabular}


- 콘텐츠 이용자들에 대한 정보 파악시, 시의성 자체를 주 목적으로 한다면, 이와 같은 조사통계 자료보다 비정형 빅데이터를 활용한 여론 및 반응 데이터 활용이 더 효율적일 수 있음

- 이와 비교하여, 단기간, 제한된 예산 및 여타 조건에 의해 특수한 목적이 발생할 경우에는 이러한 시의적 조사통계 자료는 다양한 목적 달성을 위해 필요하므로, 일반적으로 가장 활발하게 생산되는 형태임. 다만 공공 영역에서 질적 향상을 위해 지원 예산 및 인력 등에 지원을 강화할 필요성이 있음 


\section{제2절 콘텐츠 이용자 조사안}

\section{1. 콘텐츠 이용자 조사 분류체계}

- 본 연구에서 콘텐츠 이용자 조사안을 제시하며, 우선적으로 그 분류체계를 제안하 는 이유는 장기적인 정보 축적의 가치가 있는 분야의 정의와 범주를 구체화할 필요 성 때문임

- 콘텐츠 이용자 조사의 가장 큰 차별성은 '콘텐츠산업 특수분류체계”를 최대한 적용 하여 콘텐츠 장르 간 비교가 가능하도록 한 것임

- 이 때, 콘텐츠 이용자들의 실질적인 콘텐츠 이용양상을 고려하여, 광고, 지식정 보, 콘텐츠솔루션 3 개 특수분류 범주를 제외함. 전문가 자문과정에서, 뉴스나 교육, 정보 활동과 관련된 측정을 '지식정보' 범주와 관련하여, 별도 분류체계로 범주화해야할 것인지에 대한 이견이 다소 확인된 바 있으나, 이러한 텍스트(문 서, 문자) 중심의 정보 콘텐츠는 별도로 구분하지 않더라도 측정될 수 있다는 의견을 참조하였음

- 한편, 이용자들의 참여에 의한 콘텐츠 생산과 소비가 활발해지는 'SNS'에 대해 서도 별도 분류로 범주화할 것인지에 대한 자문 결과, SNS가 현재까지는 콘텐 츠보다 플랫폼 정의에 가깝고, 이용자들에 의한 SNS 생산 콘텐츠에 대한 처리 는 보다 심층적인 전문적 논의가 필요하다는 의견을 참조하였음

- 본 연구에서 콘텐츠 이용 범주를 파악할 수 있는 기존 주요 조사통계를 검토한 결 과, 각 자료별로 매우 이질적인 이용행태 범주가 적용되고 있음을 확인한 바 있음

- 예를 들어, 콘텐츠 이용행태가 지나치게 압축적으로 측정되고 있거나, 일부 콘 텐츠의 측정 가능성이 누락된 경우가 많았음

- 또는 인터넷이나 방송처럼 특정 분야에서 발생하는 이용행태만 집중적으로 범 
주화하여, 다른 콘텐츠 장르의 이용양상과 비교 검토를 할 수 있는 가능성이 제 한된 자료들도 많았음

- 한편, 만화나 영상, 게임 등의 일부 분야는 조사대상에게 유해한 매체라는 관점 에서 설계된 자료들도 확인되었음

- 이에 따라, 콘텐츠 이용자 조사의 분류체계는 '출판, 만화, 애니메이션, 캐릭터, 게 임, 영화, 방송, 음악, 공연' 9개로 구분함

- 통계법상 '콘텐츠산업 특수분류체계’를 최대한 유지하여, 통계 이용자들의 혼란 을 초래하지 않도록 함

- 콘텐츠 이용행태 측정시에는 '온라인' 행동과 '오프라인' 행동이 장르별로 모두 측정되도록 하였음

- 또한 그동안 콘텐츠 이용행태로 자주 누락되어 온 ‘공연’ 분야를 추가하여, 온. 오프라인 이용양상이 균형적으로 측정되도록 하고, 기존의 오프라인 중심의 공 연 분야가 급속도로 온라인 콘텐츠로 소비되고 있는 부분 또한 장기적으로 측정 될 수 있도록 함

〈표 5-8〉 콘텐츠 이용 분류안

\begin{tabular}{|c|c|c|}
\hline \multicolumn{2}{|c|}{ 기존 주요 자료 검토 결과 } & \multirow{2}{*}{ 조사 분류 제안 } \\
\hline 국가승인통계조사 & 콘텐츠 이용 분류 & \\
\hline 국민문화예술활동조사 & 영화, 공연 & \multirow{7}{*}{$\begin{array}{l}\text { 출판, 만화, 애니메이션, } \\
\text { 캐릭터, 게임, 영화, 방송, } \\
\text { 음악, 공연 } \\
\text { (9개 범주) }\end{array}$} \\
\hline 국민여가활동조사 & 출판, 만화, 음악, 게임, 영화, 방송, 공연 & \\
\hline 생활시간조사 & 출판, 음악, 게임, 방송, 문화활동(공연 등) & \\
\hline 한국미디어패널조사 & 출판, 음악, 게임, 영화, 방송 & \\
\hline 인터넷이용실태조사 & 출판, 음악, 게임, 영화, 방송, & \\
\hline 방송매체이용행태조사 & 방송(하위 범주 세분화) & \\
\hline 청소년 매체이용 및 유해환경 실태조사 & 출판, 만화, 게임, 방송 & \\
\hline \multicolumn{3}{|c|}{$\begin{array}{l}\text { 자료: 문화체육관광부(2020), } 2020 \text { 국민문화예술활동조사, 문화체육관광부(2020), } 2020 \text { 국민여가활동조사, 통계청 } \\
\text { (2019), } 2019 \text { 생활시간조사, 정보통신정책연구원(2020), } 2020 \text { 한국미디어패널조사, 과학기술정보통신부(2020), } \\
2020 \text { 인터넷이용실태조사, 방송통신위원회(2020), } 2020 \text { 방송매체이용행태조사, 여성가족부(2020), } 2020 \text { 청소년 } \\
\text { 매체이용 및 유해환경 실태조사 재정리 }\end{array}$} \\
\hline
\end{tabular}




\section{2. 콘텐츠 이용자 조사 프레임}

\section{가. 설계 개요}

- 현재 특정 콘텐츠 분야로 한정된 조사통계 자료들이 단순히 기술적인 콘텐츠 이용 량을 보고하거나, 향후 콘텐츠 정책 수립이나 산업 정보 제공에 도움이 될만한 인 과적 요소를 누락한 자료가 많았다는 점을 고려하여, 다음과 같은 조사 프레임을 제안함

- 콘텐츠 이용자 조사는 다양한 장르의 이용 현황을 1 개 조사에서 종합적으로 측정 할 수 있도록 전문가 자문 결과에 따라 핵심 정보를 중심으로 보수적인 설계를 지 향하였음

- 조사목적은 '우리나라 국민의 콘텐츠 이용 현황과 인식을 종합적으로 파악하여, 향후 콘텐츠 산업 정책 수립에 기초자료로 활용하기 위함임

- 조사대상은 시작 연령은 만 10 세 이상으로 설정하되, 연령 상한선에 제한을 두지 않도록 함

- 조사대상의 연령 범위는 실제 조사에 투입할 수 있는 예산 규모와 방법에 따라 크게 좌우됨

- 만약 조사 예산이 충분하다면, 미성년을 포함하여 보다 풍부한 정보를 수집할 수 있으나, 정확한 정보수집이 어려울 수 있으므로, 앞서 1절에서 제안한대로 초등학생이 조사대상에 포함될 경우, 부모 입회 하에 조사하거나 일부 정보를 부모에게 수집하는 방법이 병행되어야 할 것임

- 조사방법은 현재, 대면조사나 온라인 조사가 모두 가능하도록 설계하였음

- 조사방법 또한 예산 규모와 목적에 따라 크게 좌우됨

- 온라인 조사는 PC 또는 모바일 조사를 모두 포함하는 개념이나, 모바일 조사 비중이 늘어날 경우 현재 제안하는 내용보다 더 많은 압축 작업이 요구됨

- 국가승인통계를 목적으로 할 경우, 승인화 절차를 위하여 반드시 대면조사로 진 행해야 하며, 이에 맞추어 조사대사의 연령 범위도 확장 가능함 
〈표 5-9〉 콘텐츠 이용자 조사 프레임 안

\begin{tabular}{|c|c|}
\hline 구분 & 내용 \\
\hline $\begin{array}{l}\text { 응답자 일반현황 } \\
\text { (사회경제적 요인) }\end{array}$ & 성, 연령, 지역, 학력, 경제활동여부, 소득, 직업, 가구유형 \\
\hline 콘텐츠 이용 경험 & $\begin{array}{l}\text { - 콘텐츠 이용 장르 } \\
\text { - 콘텐츠 주 이용 기기 } \\
\text { - 콘텐츠 이용 장르별 평균 이용시간(평일, 주말 구분 시간일지) } \\
\text { - 콘텐츠를 주로 이용하는 장소 } \\
\text { - 콘텐츠 이용 상황(혼자, 함께 이용하는 사람) } \\
\text { - 콘텐츠 장르별 유료결재 경험 및 금액 } \\
\text { - 콘텐츠 지출 내용(콘텐츠 서비스, 어플리케이션, 관련 상품 구매) }\end{array}$ \\
\hline 콘텐츠 이용 인식 & $\begin{array}{l}\text { - 관련 정책 및 사회적 이슈 } \\
\text { (문화가 있는 날, 주52간제, 할인 혜택 및 무료 이용, } \\
\text { 개인정보보호, 셧다운 제도, 성인지 감수성) } \\
\text { - 평소 삶의 만족도 } \\
\text { - 평소 건강 }\end{array}$ \\
\hline
\end{tabular}

\section{나. 일반 현황}

- 콘텐츠 이용자들의 사회경제적, 인구학적 특성을 파악할 수 있는 정보는 성, 연령, 지역, 학력, 직종 및 종사상지위, 소득, 그리고 가구유형으로 최대한 상세히 수집하 도록 하였으며, 조사 흐름을 고려하여 전반부의 '응답자 일반 현황'과 후반부 '배경 질문'으로 구분하여 배치함

- 이는 사회계층별 각 요소에 따라, 콘텐츠 이용양상의 변화가 어떻게 다른지를 검토할 때 활용 가치가 높은 기초정보이나, 기존의 많은 조사통계 자료에서 수 집시 누락된 정보들임

\section{$\mathrm{SQ}$ 응답자 일반 현황}

1 귀하의 성별은 무엇입니까? $\quad$ (1) 남성 $\quad$ (2) 여성

2 귀하의 출생연도를 기입해주십시오 0000 년

3 귀하께서 현재 거주하시는 지역은 다음 중 어디입니까?

\begin{tabular}{|c|c|c|}
\hline $\begin{array}{l}\text { (1) 서울특별시 } \\
\text { (5) 광주광역시 } \\
\text { (9) 강원도 } \\
\text { (1) 전라북도 }\end{array}$ & $\begin{array}{l}\text { (2) 부산광역시 } \\
\text { (6) 대전광역시 } \\
\text { (10) 충청북도 } \\
\text { (14) 전라담도 }\end{array}$ & $\begin{array}{l}\text { (3) 대구광역시 } \\
\text { (7) 울산광역시 } \\
\text { (11) 충청남도 } \\
\text { (15) 경상북도 }\end{array}$ \\
\hline
\end{tabular}




\section{III 배경질문}

15 귀하는 다음 중 정규 교요을 어느 과정까지 받았습니까?

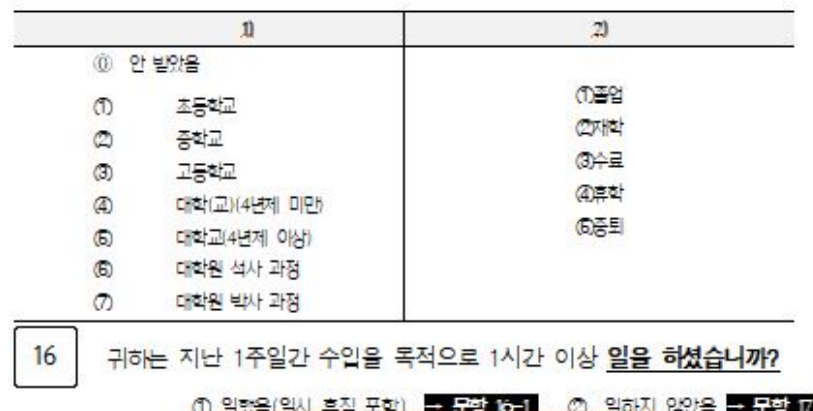

16-1 직장(일)에서 귀하의 근로형베금 무엇익니까? 문항 16-2

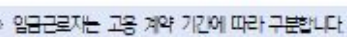

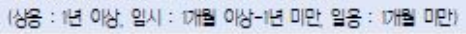
(1) 일크르르자
Q. 고종오이 이느ㅈㅏㅏㅇㅇㅇㅁㅈㅏ
(1) 상옹르르자
(3) 고옹옹이 얼는 자영업자
(2) 입시를르자
(4) 무큽 가족 증사자
(3) 일옹그르자

(5) 기타 픙사자(트수형유르르 증사자 등

16-2 귀하의 직업은 다음 중 무엇에 해당합니까?

$\rightarrow$ 문항 ㅁ
(1) 관라자
() 전원가 믹 관련 종시자
(3) 사무 종사자
(4) 서비스 종 자
(2) 판대 종 자
(ㄷ) 흥립어업 픙사자
(7) 기흥의 민 관련 기능 증사자
(8) 장지, 기계 조작 민 조립 종나자

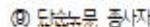
(ii) 군인

17 귀하가 현재 살고 있는 가구유형은 다음 증 무엇익니까?
(1) 인 가구
Q 2인 가구
(5) 5 인 아앙
(3) 3 인 가구
(6) 가타

18 귀하의 월평균 소득(세금 공제 후 금역은 얼마임니까?
1) 톤인 소득
만원
2) 가구 소득 (
만원

19 다음 증 귀하(귀하의 가구 포합)께서 보유하고 있는 콘르츠 이용 기기클 모두 선력해주심시오.
(1) TV
Q 겁퓨터(노트륵 포합)
(3) 태브ㄹㅣㅣㄴ
(4) 스미트폳
(5) 오디오 기기|드루투스 스피커 포합.
(6) 게일기
(7) 그타 


\section{다. 이용 경험}

- 콘텐츠 이용행태는 크게 콘텐츠 이용경험 및 이용인식으로 구분하여 설계하였음 - 콘텐츠 장르별 이용경험은 '시간할당이론' 구조를 중점적으로 적용하여, 이용 '시간, '지출', '기기'를 확인할 수 있도록 함

- 콘텐츠 이용경험을 파악하는 도입부에서는 우선, 지난 1 달간의 전반적인 콘텐츠 이용 내용을 회상하여, 전 영역의 평균 이용 행태를 응답할 수 있도록 설계하였음 - 만화는 주로 이용이 활발한 웹툰의 업데이트 주기가 1 주일인데 비해, 영화 작품 은 1달에서 3 개월 등 상영 주기가 다양함. 전문가 자문을 거쳐 이러한 차이를 고려하여 응답자의 회고 시, 응답 오류 가능성이 낮은 기간을 1 달로 설정함

- 이어, 최근 1 주일간 가장 많이 이용한 콘텐츠 3 가지와 각각의 주 이용기기를 파악 할 수 있도록 함

- 이는 이용자가 조사시점 기준, 이용중인 콘텐츠 간의 선호도와 이용기기의 확인 하기 위함임

- 다음으로, 최근 1 주일간 평일 및 주말 각 하루씩, 이틀치의 콘텐츠 이용 시간을 회고하여 기입하도록 함

- 이 때 평일과 주말 각 하루로 구분한 이유는 실제 이용 시간 차이가 크기 때문이 며, 회고 주기는 오류 가능성이 낮은 기간에 대해 전문가 검토를 거침 


\section{| 콘텐츠 이용 경험}

* 다음은 귀하의 큰턴츠 이응 경협읍 잌아보기 우한 내응입나다.

군항을 읽고 아래 표에 치튜해 주십시오.

4 귀하께서는 지난 달 갂 다음의 콘텐츠를 이용하신 경험이 있습니깐?

모두 산해ㅎㅏㅏㅇㅕ 주십시오.

\begin{tabular}{|c|c|c|}
\hline \multirow{2}{*}{ 군분 } & \multirow{2}{*}{ 이응 경험 } & 〈보기 \ \\
\hline & & 콘덴츠 유형 \\
\hline 1) 즉판 & (1) 있을 () 없음 & 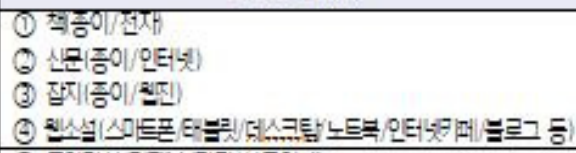 \\
\hline 2) 민화 & (1) 있음 $(2)$ 없음 & 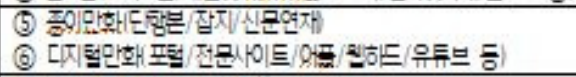 \\
\hline 3) 여뎨이션 & (1) 있음 \& 엄음 & 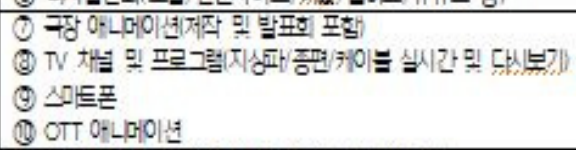 \\
\hline 4) 캐랴터 & (1) 있읍 () 어을 & 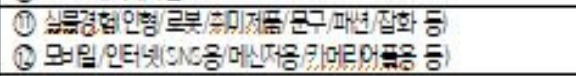 \\
\hline 5) 거임 & (1) 있읍 (2) 없음 & 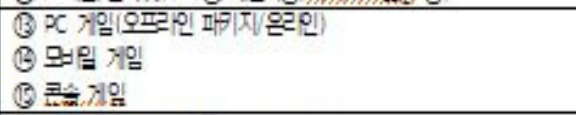 \\
\hline b) 햐하 & (1) 있읍 (2) 어음 & 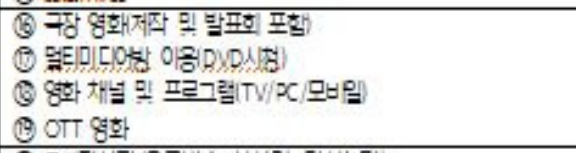 \\
\hline 7) 방옹 & (1) 있읍 () 어음 & 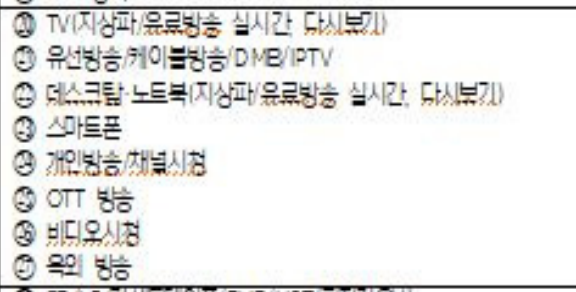 \\
\hline в) 음아 & (1) 있읍 \&) 엉음 & 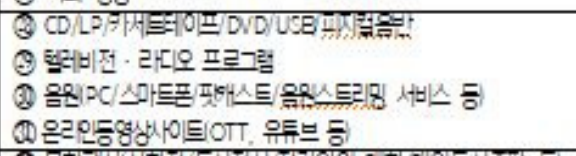 \\
\hline 9) 공연 & (1) 있읍 $Q$ 엉음 & 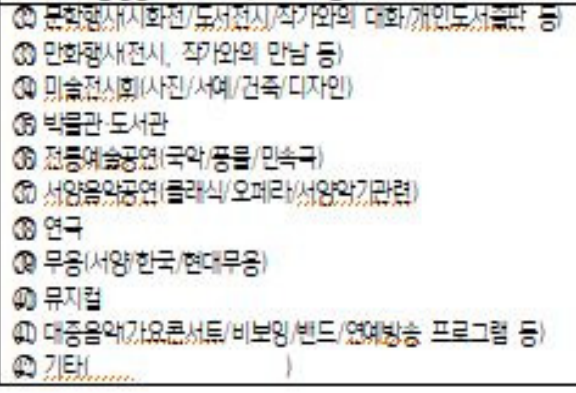 \\
\hline
\end{tabular}




\section{5 최근 1주일 간 가장 망이 이양한 폰첸츠는 무엇입니까? 순서대로 상위 3찌를 용답해주십시오.}

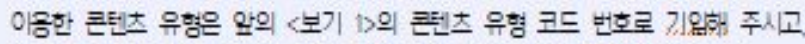
주 이응 기기 다을 〈보기 2 의 이응 기기 코드 번호로 긱용해 주십시오.

\begin{tabular}{|c|c|c|c|c|c|}
\hline \multicolumn{4}{|c|}{ 구분 } & $\begin{array}{c}\text { 7-1) } \\
\text { 콘텐츠 유형 }\end{array}$ & $\begin{array}{c}\text { 7-2) } \\
\text { 주 야응기 }\end{array}$ \\
\hline \multirow{2}{*}{\multicolumn{3}{|c|}{ 가장 많이 이항한 콘턴츠 }} & 순위 & & \\
\hline & & & 2순위 & & \\
\hline & & & 순위 & & \\
\hline \multirow{2}{*}{\multicolumn{6}{|c|}{$\begin{array}{c}\text { 〈보기 〉 } \\
\text { 이용 기기 코드 }\end{array}$}} \\
\hline & & & & & \\
\hline 규눈 & 쿄드 & \multicolumn{4}{|c|}{ 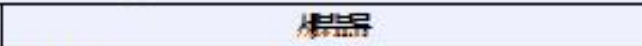 } \\
\hline \multirow{2}{*}{ 픙이마체 } & & \multicolumn{4}{|c|}{ 신믄 + 낵/잡지 } \\
\hline & \multicolumn{5}{|c|}{2 그림사진 } \\
\hline & \multirow{3}{*}{\multicolumn{5}{|c|}{ 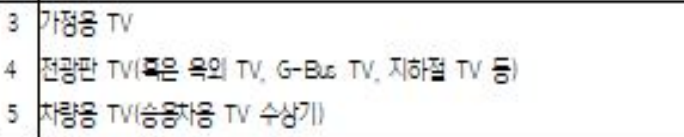 }} \\
\hline TV & & & & & \\
\hline & & & & & \\
\hline \multirow{4}{*}{ 컵퓨더 } & \multicolumn{5}{|c|}{0 에스크틀 $P C$} \\
\hline & \multicolumn{5}{|c|}{7 느트큭 PC } \\
\hline & & \multirow{2}{*}{\multicolumn{4}{|c|}{ 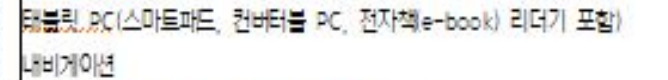 }} \\
\hline & 9 & & & & \\
\hline 전화기 & 10 & \multicolumn{4}{|c|}{ 스마트픈(스마트픈 제어 스맘ㅌㅌ아하)/변드 프햅) } \\
\hline \multirow{4}{*}{ 오디오 가기 } & 11 & \multicolumn{4}{|c|}{ 잌반 라디오리다오 전응 수신기) } \\
\hline & \multicolumn{5}{|c|}{ 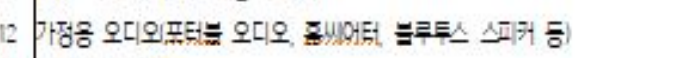 } \\
\hline & \multicolumn{5}{|c|}{3 자흥차 오디오 } \\
\hline & 14 & \multicolumn{4}{|c|}{ 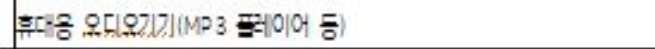 } \\
\hline \multirow{2}{*}{ 비디오 재영늑화 기기 } & 15 & \multicolumn{4}{|c|}{ VICR } \\
\hline & 10 & \multicolumn{4}{|c|}{ 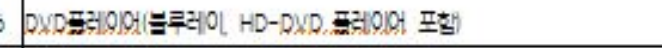 } \\
\hline \multirow{2}{*}{ 기입기 } & \multicolumn{5}{|c|}{ 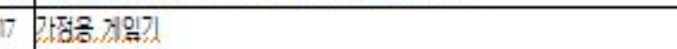 } \\
\hline & \multicolumn{5}{|c|}{18 후다응 거일기 } \\
\hline$V R / A R$ & 19 & \multicolumn{4}{|c|}{ VR/AR가상 증강현실 기기 } \\
\hline
\end{tabular}




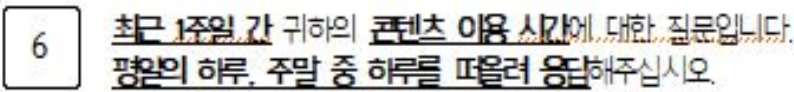

\begin{tabular}{|c|c|c|c|c|c|c|c|c|c|c|}
\hline \multicolumn{11}{|c|}{ 평입 응응시간 } \\
\hline 구분 & $\begin{array}{c}\text { 모점 } \\
\text { 다에에 }\end{array}$ & 오엄에 & $\begin{array}{l}\text { 오전 } \\
9-1241\end{array}$ & $\begin{array}{c}\text { 오후 } \\
12+1 \text { }\end{array}$ & $\begin{array}{c}\text { 오호 } \\
\text { 썬씨 }\end{array}$ & $\begin{array}{c}\text { 오후 } \\
\text { 가에시 }\end{array}$ & $\begin{array}{l}\text { 오후 } \\
\text { 애세서 }\end{array}$ & $\begin{array}{c}\text { 오후 } \\
\text { 8-10시 }\end{array}$ & 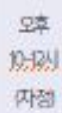 & 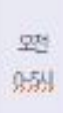 \\
\hline 1) 졸판 & 168 & & & & & & & & & \\
\hline 2) 민화 & & & & & & & & & & \\
\hline 3) 아다엉 & & & & & & & & & & \\
\hline 4) 카락터 & & & & & & & & & & \\
\hline 5) 개임 & & & & & & & & & & \\
\hline ㅇ) 영하 & & & & & & & & & & \\
\hline 7) 방송 & & & & & & & & & & \\
\hline 혀 음아 & & & & & & & & & & \\
\hline 9) 공연 & & & & & & & & & & \\
\hline \multicolumn{11}{|c|}{ 주말 응응 시간 } \\
\hline 구분 & $\frac{\text { 모정 }}{5-6 ㅅ N ~}$ & $\frac{\text { 모전 }}{6 ㅇ ㅔ ~}$ & $\begin{array}{l}\text { 오전 } \\
9-1241\end{array}$ & 오호 & $\begin{array}{c}\text { 오호 } \\
\text { 싼ㅆㅆ }\end{array}$ & $\begin{array}{c}\text { 오후 } \\
\text { 가세시 }\end{array}$ & $\begin{array}{l}\text { 오후 } \\
\text { \{젹세 }\end{array}$ & $\begin{array}{l}\text { 오후 } \\
\text { a-10시 }\end{array}$ & $\begin{array}{l}\text { 오후 } \\
\text { 서거기 } \\
\text { 자점 }\end{array}$ & $\frac{\text { 모단 }}{85 ㅅ ㅣ ㄴ ~}$ \\
\hline 1) 족판 & $108 \times 10$ & & & & & & & & & \\
\hline 2) 민화 & & & & & & & & & & \\
\hline 3) 아다엉 & & & & & & & & & & \\
\hline 4) 캐릭터 & & & & & & & & & & \\
\hline 5) 개일 & & & & & & & & & & \\
\hline ㅇ) 8 화 & & & & & & & & & & \\
\hline 7) 봉옹 & & & & & & & & & & \\
\hline ㅎ) 음아 & & & & & & & & & & \\
\hline 9) 공연 & & & & & & & & & & \\
\hline
\end{tabular}

- 콘텐츠를 주로 이용한 장소 및 함께 이용한 사람에 대한 질문은 최근 콘텐츠 이용 행태 파악시, 이용의 맥락을 파악하기 위해 수집하는 정보이기 때문임

- 주로 이용한 장소는 다양한 장소들을 복수로 선정할 수 있도록 구성함

- 함께 이용한 사람은 '혼자’를 포함하여 가족, 친구, 직장동료, 동호회, 기타 등 선택의 폭을 다양하게 제시하되, 순서대로 기입할 수 있도록 하여, 평소 콘텐츠 이용의 사회관계적 환경을 파악할 수 있도록 함 


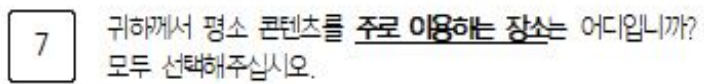

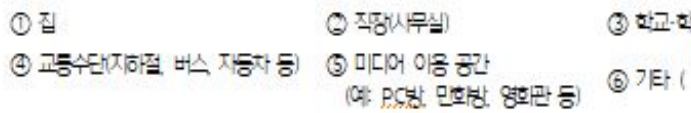

8 귀하께서는 콘텐츠를 주로 누구와 햄께 이용하십니까?

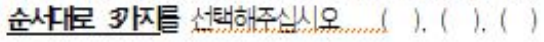
(1) 혼자
Q 가족(친척 포한)가 흔게
(3) 친구연인 포한아 흘께
(ㄷ) 직앙 향르
(ㄱ) 등호희(종교든체 등 포한) 회온가 항게
(6) 기태

- 콘텐츠 지출에 있어서는 유료 결재 경험 및 내역을 1 달 단위로 회고하여 응답할 수 있도록 설계함

- 먼저 각 콘텐츠 유형별로 이용 경험 여부를 확인하여, 1 달 기준 결재 금액 총액 을 기입할 수 있도록 함

- 이와 별도로 구독서비스, 어플리케이션, 그 외 콘텐츠와 관련된 추가 상품 구입 경험 여부와 금액을 기입할 수 있도록 함

- 이를 통해, 평소 콘텐츠 이용에 동원 가능한 구매력의 정도를 파악하고, 콘텐츠 이용 구독 서비스의 결재 규모, 나아가 보다 적극적으로 어플리케이션이나 관련 상품의 구매에 이르기까지 지출 행동이 확장되는지를 함께 파악할 수 있도록 함

9 지난 1달간 다늠의 콘텐츠를 이방하기 위해 뷰료 결제틀 하신 적이 빘습니 까? 있다뎐, 금액을 휩께 기입해주새씽ㅇ.

(모든 콘텐츠에 대해 유료겨⿸제 경혐이 업으면 문항 10번으로 이동)

\begin{tabular}{|c|c|c|c|}
\hline 콘텐츠 유형 & 이응 경험 & \multicolumn{2}{|c|}{ 개새 . 709} \\
\hline 1) 즉판 & (1) 있을 Q 엉읍 & 1 & 28 \\
\hline 2) 민화 & (1) 있읍 () 엉읍 & 1 & 8 \\
\hline 으므이션 & (1) 있읍 Q 엉음 & 1 & 원 \\
\hline 4) 캐륵터 & (1) 있을 @ 영음 & 1 & 원 \\
\hline 5) 거임 & (1) 있읍 () 영응 & 1 & 원 \\
\hline 하 8하 & (1) 있읍 Q 영음 & 1 & 원 \\
\hline 7) 방송 & (1) 있읍 () 연음 & 1 & 원 \\
\hline a) 음아 & (1) 있읍 () 영읍 & 1 & 28 \\
\hline 9) 공연 & (1) 있을 Q 영용 & 1 & 인 \\
\hline
\end{tabular}


귀하의 콘텐츠 관련 서비스 및 상푿 구매에 대하 질류일니다.

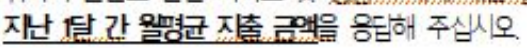

\begin{tabular}{|c|c|c|c|}
\hline 행믁 & 응응 여쿠 & 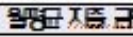 & \\
\hline 10-1) 구듀서비스 곡페 & $\begin{array}{l}\text { (1) 예 } \\
\text { (2) 아내오. }\end{array}$ & 만 & 전 원 \\
\hline 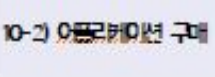 & $\begin{array}{l}\text { (1) 예 } \\
\text { (2) 애개오. }\end{array}$ & 만 & 천 원 \\
\hline 10-3) 폰처 곤련 상품 & $\begin{array}{l}\text { (1) 예 } \\
\text { (2) 애내오. }\end{array}$ & 만 & 천 원 \\
\hline
\end{tabular}

\section{라. 이용 인식}

- 다음으로 콘텐츠 이용 인식에 있어서는 각 콘텐츠 별 이용 만족도, 콘텐츠 관련 정책 및 사회적 이슈에 대한 동의 정도, 그리고 평소 삶의 질과 관련된 정보를 압 축적으로 수집할 수 있도록 설계함

- 콘텐츠 별 이용 만족도 응답시에는 평소 잘 이용하지 않는 콘텐츠는 응답하지 않아도 되게 설계하여, 이용 패턴을 파악할 수 있게 함. 이를 통해 특정 콘텐츠 를 이용하는 사람인지, 다양한 콘텐츠를 이용하는 사람인지를 파악할 수 있는 가능성을 확보하도록 함

- 콘텐츠 관련 정책 및 사회적 이슈에 있어서는 현재 시점을 기준으로 측정 가치 가 있는 내용을 전문가 자문을 통해 수렴한 결과에 기반하여 압축적으로 구성 함. 이는 향후 필요시 조정할 수 있는 항목으로, 제도에 대한 이용자 인식을 확 인하고자 함이 주 목적임

- 평소 이용자의 전반적인 삶의 만족도와 건강에 대한 인식을 별도로 구분하여 측정하도록 함

- 삶의 만족도 및 건강은 삶의 질 지표 가운데 가장 대표적으로 활용되는 측정 항목임. 최근 정신적, 정서적 만족 상태를 측정하는 '전반적인 삶의 만족도'와 육체적 건강을 주관적으로 판단한 결과인 '건강' 상태를 구분하여 측정하는 추 세를 반영함. 이 가운데, 육체적 건강에 대한 주관적 인식은 본인의 건강이 별로 좋지 않다고 판단할수록 실제 건강이 좋지 않을 가능성이 높거나, 수명에 영향 을 주는 확률이 높다는 최신 연구 트렌드를 반영한 결과임 


\section{\| 콘텐츠 이용 인식}

11 귀하의 평소 콘텐츠 이용에 대한 만족도를 표시해주십시오. 잘 이용하지 않는 콘텐츠는 응답하지 않으셔도 됩니다.

\begin{tabular}{|c|c|c|c|c|c|}
\hline 콘덴츠 유형 & $\begin{array}{l}\text { 메우 } \\
\text { 콘목 }\end{array}$ & $\begin{array}{l}\text { 가의 } \\
\text { 큰몬 }\end{array}$ & 보동 & $\begin{array}{l}\text { 다차로 } \\
\text { 만족 }\end{array}$ & 매우 만쪽 \\
\hline \multicolumn{6}{|l|}{ 1) 즉판 } \\
\hline \multicolumn{6}{|l|}{ 2) 만화 } \\
\hline \multicolumn{6}{|l|}{$\exists$ 에드이션 } \\
\hline \multicolumn{6}{|l|}{ 4) 캐른터 } \\
\hline \multicolumn{6}{|l|}{ 5) 게일 } \\
\hline \multicolumn{6}{|l|}{ 하 영하 } \\
\hline \multicolumn{6}{|l|}{ 7) 방송 } \\
\hline \multicolumn{6}{|l|}{ ㅎ) 음아 } \\
\hline 9) 공연 & & & & & \\
\hline
\end{tabular}

12 콘텐츠 이용과 관련하여 귀하의 평소 생각을 여쭐고자 합니다.

12 다음과 같은 정책 및 시회적 이슈에 대해, 동의하는 수준을 표시해주십시오.

\begin{tabular}{|c|c|c|c|c|c|}
\hline 폰츠 이영과 곤를한 평소 인식 & 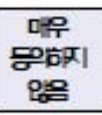 & $\begin{array}{l}\text { 당 } \\
\text { 하이 } \\
\text { 잉 }\end{array}$ & 보동 & 둥함 & $\begin{array}{c}\text { 매우 } \\
\text { 둥할 }\end{array}$ \\
\hline 1 문아강ㅇㄴ는 낰 & (1) & Q & (3) & (4) & (5) \\
\hline 2) 주 5x18. 제 & (1) & Q & (3) & (4) & (5) \\
\hline 3 응인 해택 및 무료 응 & (1) & Q & (3) & (4) & (5) \\
\hline 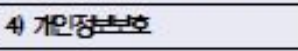 & (1) & $Q$ & (3) & (4) & (5) \\
\hline 5) 섯드우 제다 & (1) & Q & (3) & (4) & (5) \\
\hline 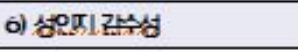 & (1) & Q & (3) & (4) & (5) \\
\hline
\end{tabular}

13 귀하께서는 평소 자신의 잩반작인 소어 을마나 만족하십니까?

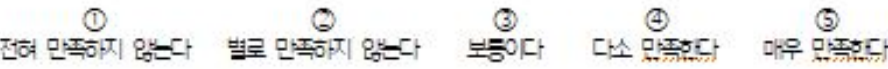

14 귀하의 평소 건강은 어뗳다고 생각하십니까?

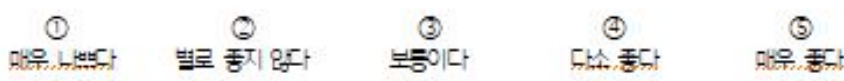

- 이러한 제안은 현재까지 콘텐츠 이용자 층위에서 콘텐츠 장르 간 이용양상의 변화 를 체계적으로 검토할 수 있는 자료의 부재에 대한 문제의식에 따라, 장르 간 상호 비교가 가능한 일관적인 측정 체계를 마련하고자 한 결과임

- 향후 정책 시사점을 더 세밀하게 도출할 수 있는 부가 데이터 개발이 활발해질 수 있도록, 이러한 기초 중심데이터의 구축이 요구됨 


\section{제3절 콘텐츠 이용자 행동 데이터 활용}

\section{1. 로그 데이터}

- 콘텐츠 이용자 층위에서는 $\mathrm{PC}$ 나 스마트폰과 같이 콘텐츠 이용과 밀접한 사용관계 에 있는 특정 기기에 특화된 이용정보를 수집할 수 있음

- 로그 데이터는 기기 기반의 이용 정보를 수집하는 별도의 소프트웨어를 통해, 정보 제공과 설치 동의가 허락된 이용자들의 웹로그 기록을 수집, 가공하여, 최종적으로 이용자들의 특정 서비스에 대한 행동 분석이 가능함

- 이러한 로그데이터는 대부분 현재 민간 기업 내부에서는 비교적 활발하게 활용 될 수 있으나, 외부에서의 접근 가능성은 매우 제한적임

- 현재 국내 거주자를 무작위 층화추출하여, PC 및 모바일 운영체제별 사용자 패 널을 대상으로 실시간 수집 로그 데이터를 활용하고 있는 시례가 확인됨

- 로그 데이터는 콘텐츠 이용행태를 장르별, 채널별, 프로그램별, 상품별, 플랫폼별 로 매우 구체적으로 구분하여 파악할 수 있다는 장점이 있음

- 특히 국내 스마트폰 보유율 뿐만 아니라, 모바일, 온라인으로 콘텐츠를 활용하 는 비중이 매우 높다는 측면에서, 이러한 데이터는 현재 각 세부산업별로 경쟁 중인 사업체들의 트렌드 변화를 시의성 있게 파악할 수 있다는 장점을 확보함

- 다만 이러한 로그 데이터를 활용한 행동 분석은 기업이 내부적으로 보유한 데이터 활용한 행동 분석과는 내용상 차이가 있음 
[그림 5-1] 콘텐츠 분야 로그 데이터 활용 자료

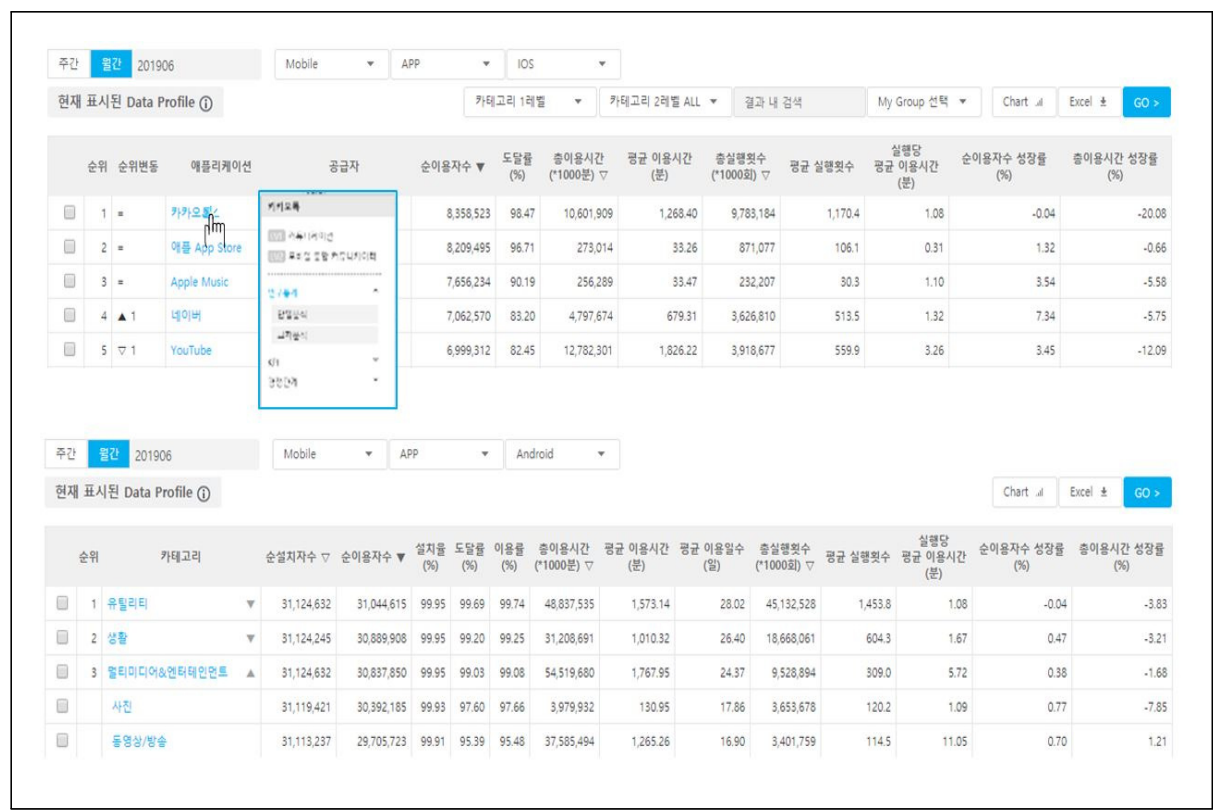

자료: 닐슨 제공

\section{2. 빅데이터}

- 콘텐츠 이용자들의 행동 패턴이 매우 복잡하고, 콘텐츠를 이용하는 기기나 채널, 플랫폼 등 서비스 경로 또한 매우 다양한 상황에서, 이러한 조사통계, 로그 데이터, 그리고 SNS 텍스트 데이터나 구매 행동 데이터 등에 이르는 비정형 빅데이터를 다양하게 활용할 가치는 높음

- 이로써, 콘텐츠 산업 전반에 의미있는 정보를 제공할 가능성을 확장할 수 있음

- 일반적으로 '빅데이터’라고 불리는 비정형 데이터는 콘텐츠 이용자들이 생산하는 SNS나 블로그, 커뮤니티 등 공개 메시지 형태가 대표적임

- 이러한 종류의 빅데이터는 시의성이나 분석 목적, 맥락 등이 매우 중요함

- 콘텐츠 커뮤니티를 중심으로 한, 특정 주제 분석에 적극 활용할 가치가 있음

- 실제로 팬덤 등 특유의 행동 분석을 진행한 사례들도 다수 확인됨

- 텍스트 데이터 외에 영상 데이터로 확장하더라도, 유튜브, 네이버 TV 캐스트 
등 콘텐츠가 생산되는 개별 사이트별로 이용 행동 분석, 감성 분석 등 다양한 형태의 기획이 가능함(이호영 외, 2019)

- 그 외에도 활용할 수 있는 빅데이터 자원은 기획 내용에 따라 매우 다양할 수 있고, 콘텐츠 특성상 각 분야별 특수성이 있어, 정보전략계획 수립 등 별도의 연구가 요구됨 


\section{참고문헌}

• 과학기술정보통신부(2020), 「2020 인터넷이용실태조사」.

- 국립중앙도서관(2018), 「도서관 빅데이터 기반 정보서비스 시스템 구축 정보화 전략 계획 수립」.

- 김성희·심상신(2018), 「현대사회의 여가와 레크리에이션, 백산출판사.

- 김소연·박찬욱·송정연·강혜승(2020), 「콘텐츠산업 분야 통계 체계구축 및 발전방안 연구」, 한국문화관광연구원.

- 문화체육관광부(2020), 「2020 국민문화예술활동조사」 .

- 문화체육관광부(2020), 「2020 국민여가활동조사」.

- 문화체육관광부(2018), 「2018 국민여가활동조사 문화향수실태조사 국내외 사례 및 시사점」.

- 방송통신위원회(2021), 방송콘텐츠 가치정보 분석시스템 검색결과.

- 방송통신위원회(2020), 「2020 방송매체이용행태조사」.

- 서울대학교 언론정보연구소(2015), 「2015 국민생활시간조사」.

- 송해룡·김원제·조항민·김찬원·이윤경·최현주·권영성·허난영·이용준·최부헌·고두희 (2019), 「미디어 콘텐츠 4.0」, 한국학술정보.

- 여성가족부(2020), 「2020 청소년 매체이용 및 유해환경 실태조사」.

- 영화진흥위원회(2021), 영화관 입장권 통합전산망 검색결과.

- 이호영·양기문·정선민·강민정·김용찬·이도훈(2019), 「지능정보사회 이용자 패널데이 터 구축 및 조사」, 정보통신정책연구원·방송통신위원회.

• 이재현(2013).「뉴미디어 이론」. 커뮤니케이션스북스.

- 정보통신정책연구원(2020), 「2020 한국미디어패널조사」.

- 중소기업청(2017), 「사용자 빅데이터를 이용한 만화·웹툰 개인화 추천 엔진 개발」.

- 통계청(2020), 콘텐츠산업 특수분류체계.

• 통계청(2019), 「2019 생활시간조사」. 
- 한국생산성본부 생산성연구소(2020), 「포스트코로나 대응을 위한 한국판 뉴딜의 핵심 전략 디지털뉴딜」.

- 한국언론진흥재단(2020), 「2020 언론수용자조사」.

- 한국저작권위원회(2021), 권리자찾기 정보시스템 디지털저작권거래소 검색결과.

- 한국콘텐츠진흥원(2020), 「2020 웹소설이용자실태조사」.

- 한국콘텐츠진흥원(2020), 「2020 만화이용자실태조사」.

- 한국콘텐츠진흥원(2020), 「2020 애니메이션이용자실태조사」.

- 한국콘텐츠진흥원(2020), 「2020 캐릭터이용자실태조사」.

- 한국콘텐츠진흥원(2020), 「2020 게임이용자실태조사」.

- 한국콘텐츠진흥원(2020), 「2020 음악이용자실태조사」.

- 한국콘텐츠진흥원(2018), 「게임이용패널 5차년도 연구」.

- 한준·김옥태·배영·윤소영·심수진(2017), 「여가 통계 프레임워크 작성 및 국가주요지 표 체계 진단연구」, 통계개발원.

- Ahmad, Nadim, and Jennifer Ribarsky. (2018). Towards a framework for measuring the digital economy, 16th Conference of the International Association of Official Statisticians.

- Becker, G. S. (1965). A Theory of the Allocation of Time. The economic journal, 75(299), 493-517.

- Center for time use research(2015). UK Time Diary Study 2014-2015.

- Department for Culture Media \& Sport(2014). Creative Industries Economic Estimates, Office National Statistics.

- Ermisch, J., Francesconi, M., Berthoud, R., \& Gershuny, J. (2000). Patterns of household and family formation. Seven years in the lives of British families, 21-44.

- Executive Office of the President of the United States(2017). North American Industry Classfication System.

- Fishbein, M., Jaccard, J., Davidson, A. R., Ajzen, I., \& Loken, B. (1980). Predicting and understanding family planning behaviors. In Understanding attitudes and predicting social behavior. Prentice Hall.

- Gershuny, J., \& Sullivan, O. (2019). What we really do all day: Insights from the centre for time use research. Penguin UK. 
- Gershuny, J., \& Thomas, G. S. (1980). Changing Patterns of Time Use: Data Preparation and Some Preliminary Results, UK, 1961-1974/5. Science Policy Research Unit, University of Sussex.

- Gibson, G., O’Faircheallaigh, C. \& MacDonald, A.(2008). Integrating Cultural Impact Assessment into Development Planning (International Association for Impact Assessment Workshop), Fargo, ND: IAIA.

- OECD(2009). Guide to Measuring the Information Society,

- U.S. Bureau of Labor Statistics(2011). American Time Use Survey Activity Lexicon 2011.

- UNESCO(2009). Framework for Cultural Statistics. 



\section{ABSTRACT}

\section{Research on Cultural Content Consumer Data Development}

Kim Soyeon

The primary goal of this research is to propose the direction for which the development of the content consumer data should be headed. It may be due to the fundamental variety of the definition of content and its range, the utilization of the content consumer information is limited to capable companies with a high understanding of the data value, which may cause digital divide between them and relatively smaller companies. Thus, it is imperative that the public sector develop the data through which the comprehensive analysis of content consumer activities can be achieved.

To this end, this study proposes to design the comprehensive survey system of the content consumers. Considering that the real-world content consumer activities, the new survey system needs to be designed to cover all areas. To do so, this study offers detailed survey questionnaires by closely examining the method and framework of the sampling design of the statistical survey. This study also proposes that a systemic approach be implemented to utilize unconstructed big data of the content consumers prevalently produced in the private sector. The implementation of the information strategy plan is expected to utilize a variety of data, which is likely to contribute to a better understanding of the content consumers.

\section{Keywords}

Content consumer data, content consumer survey, content consumer statistics, content consumer log data, content consumer unconstructed data 

콘텐츠 이용자 데이터 개발 기반연구

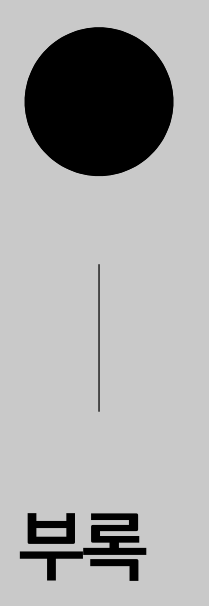





\section{콘텐츠 이용자 조사}

안녕하십니까?

본 조사는 우리나라 국민의 콘텐츠 이용 현황과 인식을 종합적으로 파악하여, 향후 콘텐츠 산업 정책 수립에 기초자료로 활용하기 위해 실시합니다.

조사 결과는 통계법 제33조(비밀의 보호)에 의하여 철저하게 보호되며, 통계적 활용 이외에는 사용되지 않습니다. 귀중한 시간을 허락하시어, 본 조사에 참여 해주셔서 진심으로 감사합니다.

20( )년 ( )월

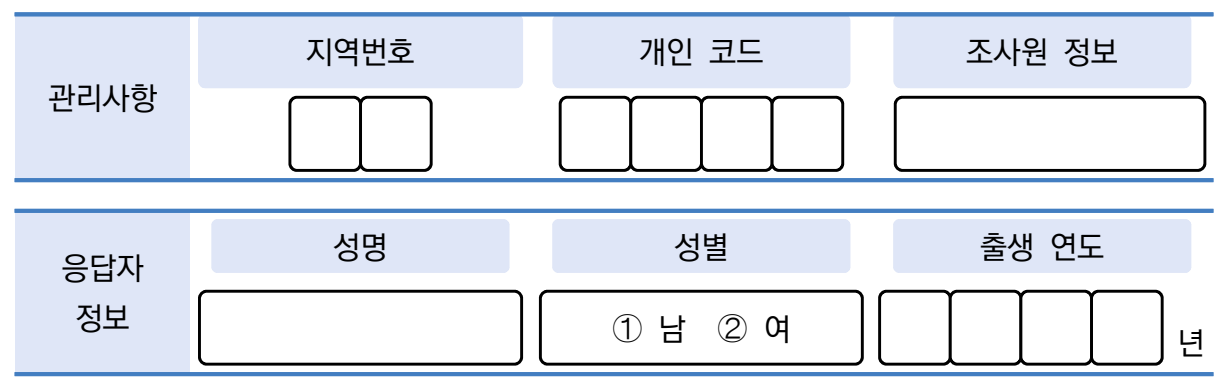

※ 조사원이 확인하여 작성합니다.

작성 요령

응답은 질문 순서대로, 보기 항목에서 해당 번호를 선택하거나, 기입해주시면 됩니다.

\section{$\mathrm{SQ}$ 응답자 일반 현황}

1 귀하의 성별은 무엇입니까? (1) 남성 1 (2) 여성

2 귀하의 출생연도를 기입해주십시오. 0000 년

3 귀하께서 현재 거주하시는 지역은 다음 중 어디입니까?
(1) 서울특별시
(2) 부산광역시
(3) 대구광역시
(4) 인천광역시
(5) 광주광역시
(6) 대전광역시
(7) 울산광역시
(8) 경기도
(9) 강원도
(10) 충청북도
(11) 충청남도
(12) 세종시
(13) 전라북도
(14) 전라남도
(15) 경상북도
(16) 경상남도
(17) 제주도 


\section{콘텐츠 이용 경험}

※ 다음은 귀하의 콘텐츠 이용 경험을 알아보기 위한 내용입니다.

문항을 읽고, 아래 표에 체크해 주십시오.

4 귀하께서는 지난 1 달 간 다음의 콘텐츠를 이용하신 경험이 있습니까? 모두 선택하여 주십시오.

\begin{tabular}{|c|c|c|}
\hline \multirow{2}{*}{ 구분 } & \multirow{2}{*}{ 이용 경험 } & \multirow{2}{*}{$\begin{array}{c}\text { 〈보기 1〉 } \\
\text { 코테츠 우현 }\end{array}$} \\
\hline & & \\
\hline 1) 출판 & (1) 있음 (2) 없음 & $\begin{array}{l}\text { (1) 책(종이/전자) } \\
\text { (2) 신문(종이/인터넷) } \\
\text { (3) 잡지(종이/웬진) } \\
\text { (4) 웹소설(스마트폰/태블릿/데스크탑/노트북/인터넛카페/블로그 등) }\end{array}$ \\
\hline 2) 만화 & (1) 있음 (2) 없음 & $\begin{array}{l}\text { (5) 종이만화(단행본/잡지/신문연재) } \\
\text { (6) 디지털만화(포털/전문사이트/어플/웹하드/유튜브 등) }\end{array}$ \\
\hline 3) 애니메이션 & (1) 있음 (2) 없음 & $\begin{array}{l}\text { (7) 극장 애니메이션(제작 및 발표회 포함) } \\
\text { (8) TV 채널 및 프로글ㅁㅁ지상파/종편/케이블 실시간 및 다시보기) } \\
\text { (9) 스마트폰 } \\
\text { (10) OTT 애니메이션 }\end{array}$ \\
\hline 4) 캐릭터 & (1) 있음 (2) 없음 & $\begin{array}{l}\text { (11) 실물경험(인형/로봇/취미제품/문구/패션/잡화 등) } \\
\text { (12) 모바일/인터넛(SNSS용/메신저용/카메라어플용 등) }\end{array}$ \\
\hline 5) 게임 & (1) 있음 (2) 없음 & $\begin{array}{l}\text { (13) PC 게임(오프라인 패키지온라인) } \\
\text { (14) 모바일 게임 } \\
\text { (15) 콘솔 게임 }\end{array}$ \\
\hline 6) 영화 & (1) 있음 (2) 없음 & $\begin{array}{l}\text { (16) 극장 영화(제작 및 발표회 포함) } \\
\text { (17) 멀티미디어방 이용(DVD시청) } \\
\text { (18) 영화 채널 및 프로그램(TV/PC/모바일) } \\
\text { (19) OTा 영화 }\end{array}$ \\
\hline 7) 방송 & (1) 있음 (2) 없음 & $\begin{array}{l}\text { (20) TV(지상파/유료방송 실시간, 다시보기) } \\
\text { (21) 유선방송/케이블방송/DMB/IPV } \\
\text { (22) 데스크탑·노트북(지상파/유료방송 실시간, 다시보기) } \\
\text { (2) 스마트폰 } \\
\text { (24) 개인방송/채널시청 } \\
\text { (26) OTा 방송 } \\
\text { (26) 비디오시청 } \\
\text { (27) 옥외 방송 }\end{array}$ \\
\hline 8) 음악 & (1) 있음 (2) 없음 & $\begin{array}{l}\text { (28) CD/LP/카세트테이프/DVD/USB/피지컬음반 } \\
\text { (29) 텔레비버넌 · 라디오 프로그램 } \\
\text { (30) 음원(PC/스마트폰/팟캐스/음원스트리밍 서비스 등) } \\
\text { (31) 온라인동영상사이트(OT, 유튜브 등) }\end{array}$ \\
\hline 9) 공연 & (1) 있음 (2) 없음 & 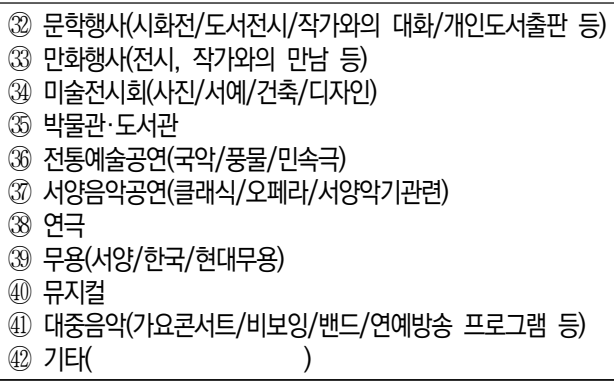 \\
\hline
\end{tabular}




\section{5 최근 1 주일 간 가장 많이 이용한 콘텐츠는 무엇입니까? 순서대로 상위 3 가지를 응답해주십시오.}

이용한 콘텐츠 유형은 앞의 〈보기 1〉의 콘텐츠 유형 코드 번호로 기입해 주시고, 주 이용 기기는 다음〈보기 2〉의 이용 기기 코드 번호로 기입해 주십시오.

\begin{tabular}{l|l|c|c}
\hline \multicolumn{2}{c|}{ 구분 } & $\begin{array}{c}\text { 7-1) } \\
\text { 콘텐츠 유형 }\end{array}$ & $\begin{array}{c}\text { 7-2) } \\
\text { 주 이용 기기 }\end{array}$ \\
\hline \multirow{3}{*}{ 가장 많이 이용한 콘텐츠 } & 1순위 & & \\
\cline { 2 - 4 } & 2순위 & & \\
\cline { 2 - 4 } & 3순위 & & \\
\hline
\end{tabular}

\section{〈보기 2〉}

이용 기기 코드

\begin{tabular}{|c|c|c|}
\hline 구분 & 코드 & 세부분류 \\
\hline 종이매체 & $\begin{array}{l}1 \\
2\end{array}$ & $\begin{array}{l}\text { 신문/책/잡지 } \\
\text { 그림/사진 }\end{array}$ \\
\hline TV & $\begin{array}{l}3 \\
4 \\
5\end{array}$ & $\begin{array}{l}\text { 가정용 TV } \\
\text { 전광판 TV(혹은 옥외 TV, G-Bus TV, 지하철 TV 등) } \\
\text { 차량용 TV(승용차용 TV 수상기) }\end{array}$ \\
\hline 컴퓨터 & $\begin{array}{l}6 \\
7 \\
8 \\
9\end{array}$ & $\begin{array}{l}\text { 데스크톱 PC } \\
\text { 노트북 PC } \\
\text { 태블릿 PC(스마트패드, 컨버터블 PC, 전자책(e-book) 리더기 포함) } \\
\text { 내비게이션 }\end{array}$ \\
\hline 전화기 & 10 & 스마트폰(스마트폰 제어 스마트와치/밴드 포함) \\
\hline 오디오 기기 & $\begin{array}{l}11 \\
12 \\
13 \\
14\end{array}$ & $\begin{array}{l}\text { 일반 라디오(라디오 전용 수신기) } \\
\text { 가정용 오디오(포터블 오디오, 홈씨어터, 블루투스 스피커 등) } \\
\text { 자동차 오디오 } \\
\text { 휴대용 오디오기기(MP3 플레이어 등) }\end{array}$ \\
\hline 비디오 재생/녹화 기기 & $\begin{array}{l}15 \\
16\end{array}$ & $\begin{array}{l}\text { VCR } \\
\text { DVD플레이어(블루레이, HD-DVD 플레이어 포함) }\end{array}$ \\
\hline 게임기 & $\begin{array}{l}17 \\
18\end{array}$ & $\begin{array}{l}\text { 가정용 게임기 } \\
\text { 휴대용 게임기 }\end{array}$ \\
\hline VR/AR & 19 & VR/AR(가상/증강현실) 기기 \\
\hline
\end{tabular}


6 최근 1주일 간 귀하의 콘텐츠 이용 시간에 대한 질문입니다. 평일의 하루, 주말 중 하루를 떠올려 응답해주십시오.

\begin{tabular}{|c|c|c|c|c|c|c|c|c|c|c|}
\hline \multicolumn{11}{|c|}{ 평일 이용 시간 } \\
\hline 구분 & $\begin{array}{c}\text { 오전 } \\
5-6 \text { 시 }\end{array}$ & $\begin{array}{c}\text { 오전 } \\
6 \text { 6시 }\end{array}$ & $\begin{array}{l}\text { 오전 } \\
\text { 9-12시 }\end{array}$ & $\begin{array}{c}\text { 오후 } \\
12-1 \text { 시 }\end{array}$ & $\begin{array}{c}\text { 오후 } \\
\text { 1사3시 }\end{array}$ & $\begin{array}{c}\text { 오후 } \\
\text { 3-6시 }\end{array}$ & $\begin{array}{c}\text { 오후 } \\
6-8 \text { 시 }\end{array}$ & $\begin{array}{c}\text { 오후 } \\
\text { 8-10시 }\end{array}$ & $\begin{array}{c}\text { 오후 } \\
\text { 10-12시 } \\
\text { (자정) }\end{array}$ & $\begin{array}{l}\text { 오전 } \\
\text { 0-5시 }\end{array}$ \\
\hline 1) 출판 & (예)30분 & & & & & & & & & \\
\hline 2) 만화 & & & & & & & & & & \\
\hline 3) 애니메이 & & & & & & & & & & \\
\hline 4) 캐릭터 & & & & & & & & & & \\
\hline 5) 게임 & & & & & & & & & & \\
\hline 6) 영화 & & & & & & & & & & \\
\hline 7) 방송 & & & & & & & & & & \\
\hline 8) 음악 & & & & & & & & & & \\
\hline 9) 공연 & & & & & & & & & & \\
\hline \multicolumn{11}{|c|}{ 주말 이용 시간 } \\
\hline 구분 & $\begin{array}{c}\text { 오전 } \\
5-6 \text { 시 }\end{array}$ & $\begin{array}{c}\text { 오전 } \\
6-9 \text { 시 }\end{array}$ & $\begin{array}{c}\text { 오전 } \\
\text { 9-12시 }\end{array}$ & $\begin{array}{c}\text { 오후 } \\
\text { 12-1시 }\end{array}$ & $\begin{array}{c}\text { 오후 } \\
\text { 1사3시 }\end{array}$ & $\begin{array}{c}\text { 오후 } \\
\text { 3-6시 }\end{array}$ & $\begin{array}{l}\text { 오후 } \\
\text { 6-8시 }\end{array}$ & $\begin{array}{c}\text { 오후 } \\
\text { 8-10시 }\end{array}$ & $\begin{array}{c}\text { 오후 } \\
\text { 10-12시 } \\
\text { (자정) }\end{array}$ & $\begin{array}{l}\text { 오전 } \\
\text { 0-5시 }\end{array}$ \\
\hline 1) 출판 & (예)30분 & & & & & & & & & \\
\hline 2) 만화 & & & & & & & & & & \\
\hline 3) 애니메이 & & & & & & & & & & \\
\hline 4) 캐릭터 & & & & & & & & & & \\
\hline 5) 게임 & & & & & & & & & & \\
\hline 6) 영화 & & & & & & & & & & \\
\hline 7) 방송 & & & & & & & & & & \\
\hline 8) 음악 & & & & & & & & & & \\
\hline 9) 공연 & & & & & & & & & & \\
\hline
\end{tabular}

7 귀하께서 평소 콘텐츠를 주로 이용하는 장소는 어디입니까? 모두 선택해주십시오.
(1) 집
(2) 직장(사무실)
(4) 교통수단(지하철, 버스, 자동차 등)
(5) 미디어 이용 공간
(예: PC방, 만화방, 영화관 등)
(3) 학교·학원
(6) 기타 $(\quad)$ 
8 귀하께서는 콘텐츠를 주로 누구와 함께 이용하십니까? 순서대로 3가지를 선택해주십시오. ( ), ( ), ( )
(1) 혼자
(2) 가족(친척 포함)과 함께
(3) 친구(연인 포함)와 함께
(4) 직장 동료
(5) 동호회(종교단체 등 포함) 회원과 함께
(6) 기타(

9 지난 1달간 다음의 콘텐츠를 이용하기 위해 유료 결제를 하신 적이 있습니까? 있다면, 금액을 함께 기입해주십시오.

(모든 콘텐츠에 대해 유료결제 경험이 없으면 문항 10번으로 이동)

\begin{tabular}{|c|c|c|c|}
\hline 콘텐츠 유형 & 이용 경험 & \multicolumn{2}{|c|}{ 결재 금액 } \\
\hline 1) 출판 & (1) 있음 (2) 없음 & ( & )원 \\
\hline 2) 만화 & (1) 있음 (2) 없음 & ( & )원 \\
\hline 3) 애니메이션 & (1) 있음 (2) 없음 & ( & )원 \\
\hline 4) 캐릭터 & (1) 있음 (2) 없음 & ( & )원 \\
\hline 5) 게임 & (1) 있음 (2) 없음 & ( & )원 \\
\hline 6) 영화 & (1) 있음 (2) 없음 & ( & )원 \\
\hline 7) 방송 & (1) 있음 (2) 없음 & ( & )원 \\
\hline 8) 음악 & (1) 있음 (2) 없음 & ( & )원 \\
\hline 9) 공연 & (1) 있음 (2) 없음 & ( & )원 \\
\hline
\end{tabular}

10 귀하의 콘텐츠 관련 서비스 및 상품 구매에 대한 질문입니다.

지난 1 달 간 월평균 지출 금액을 응답해 주십시오.

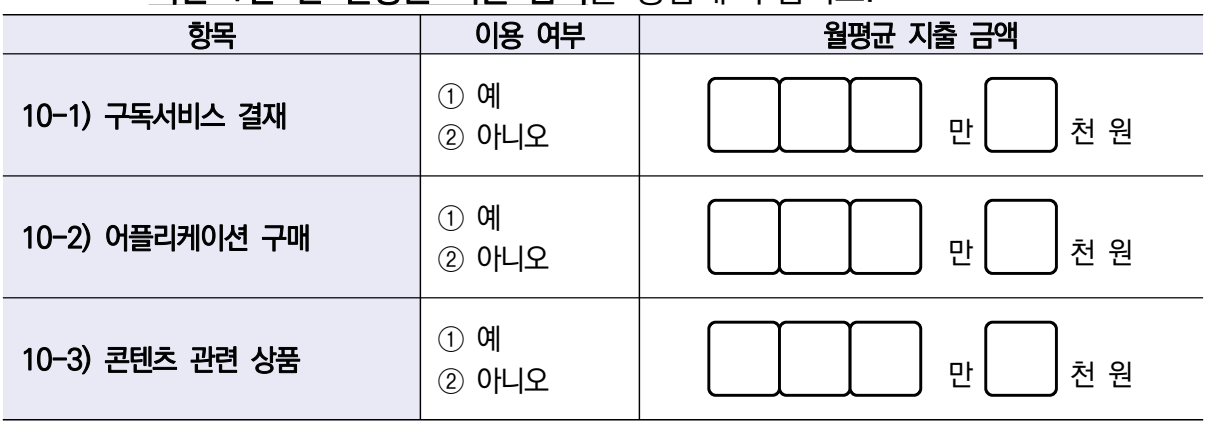




\section{II 콘텐츠 이용 인식}

11 귀하의 평소 콘텐츠 이용에 대한 만족도를 표시해주십시오. 잘 이용하지 않는 콘텐츠는 응답하지 않으셔도 됩니다.

\begin{tabular}{l|c|c|c|c|c}
\hline \multicolumn{1}{|c|}{ 콘텐츠 유형 } & $\begin{array}{c}\text { 매우 } \\
\text { 불만족 }\end{array}$ & $\begin{array}{c}\text { 거의 } \\
\text { 불만족 }\end{array}$ & 보통 & $\begin{array}{c}\text { 대체로 } \\
\text { 만족 }\end{array}$ & 매우 만족 \\
\hline 1) 출판 & & & & & \\
\hline 2) 만화 & & & & & \\
\hline 3) 애니메이션 & & & & & \\
\hline 4) 캐릭터 & & & & & \\
\hline 5) 게임 & & & & & \\
\hline 6) 영화 & & & & & \\
\hline 7) 방송 & & & & & \\
\hline 8) 음악 & & & & & \\
\hline 9) 공연 & & & & & \\
\hline
\end{tabular}

12 콘텐츠 이용과 관련하여 귀하의 평소 생각을 여쭙고자 합니다.

다음과 같은 정책 및 사회적 이슈에 대해, 동의하는 수준을 표시해주십시오.

\begin{tabular}{l|c|c|c|c|c}
\hline 콘텐츠 이용과 관련한 평소 인식 & $\begin{array}{c}\text { 매우 } \\
\text { 동의하지 } \\
\text { 않음 }\end{array}$ & $\begin{array}{c}\text { 동의 } \\
\text { 하지 } \\
\text { 않음 }\end{array}$ & 보통 & 동의함 & $\begin{array}{c}\text { 매우 } \\
\text { 동의함 }\end{array}$ \\
\hline 1) 문화가 있는 날 & (1) & (2) & (3) & (4) & (5) \\
\hline 2) 주 52시간제 & (1) & (2) & (3) & (4) & (5) \\
\hline 3) 할인 혜택 및 무료 이용 & (1) & (2) & (3) & (4) & (5) \\
\hline 4) 개인정보보호 & (1) & (2) & (3) & (4) & (5) \\
\hline 5) 셧다운 제도 & (1) & (2) & (3) & (4) & (5) \\
\hline 6) 성인지 감수성 & (1) & (2) & (3) & (4) & (5) \\
\hline
\end{tabular}

13 귀하께서는 평소 자신의 전반적인 삶에 얼마나 만족하십니까?

14 귀하의 평소 건강은 어떻다고 생각하십니까?

(1)

매우 나쁘다
(2)

별로 좋지 않다
(3)

보통이다
(4)

다소 좋다
(5)

매우 좋다 


\section{III 배경질문}

15 귀하는 다음 중 정규 교육을 어느 과정까지 받았습니까?

\begin{tabular}{cc|c}
\hline & 1) & 2) \\
\hline (1) & 안 받았음 & (1)졸업 \\
(1) & 초등학교 & (2)재학 \\
(2) & 중학교 & (3)수료 \\
(3) & 고등학교 & (4)휴학 \\
(4) & 대학(교)(4년제 미만) & (5)중퇴 \\
(5) & 대학교(4년제 이상) & \\
(6) & 대학원 석사 과정 & \\
(7) & 대학원 박사 과정 & \\
\hline
\end{tabular}

16 귀하는 지난 1주일간 수입을 목적으로 1시간 이상 일을 하셨습니까?
(1) 일했음(일시 휴직 포함)
(2) 일하지 않았음

16-1 직장(일)에서 귀하의 근로형태는 무엇입니까?

※ 임금근로자는 고용 계약 기간에 따라 구분합니다.

(상용 : 1년 이상, 임시 : 1개월 이상 1년 미만, 일용 : 1개월 미만)
(1) 임금근로자
(2) 고용원이 있는 자영업자
(3) 고용원이 없는 자영업자
(4) 무급 가족 종사자
(1) 상용근로자
(2) 임시근로자
(3) 일용근로자

(5) 기타 종사자(특수형태근로 종사자 등)

16-2 귀하의 직업은 다음 중 무엇에 해당합니까?
(1) 관리자
(2) 전문가 및 관련 종사자
(3) 사무 종사자
(4) 서비스 종사자
(5) 판매 종사자
(6) 농림어업 종사자
(7) 기능원 및 관련 기능 종사자
(8) 장치, 기계 조작 및 조립 종사자
(9) 단순노무 종사자
(10) 군인 
17 귀하가 현재 살고 있는 가구유형은 다음 중 무엇입니까?
(1) 1 인 가구
(2) 2 인 가구
(3) 3 인 가구
(4) 4 인 가구
(5) 5 인 이상
(6) 기타

18 귀하의 월평균 소득(세금 공제 후 금액)은 얼마입니까?
1) 본인 소득 (
)만원
2) 가구 소득 (
)만원

19 다음 중 귀하(귀하의 가구 포함)께서 보유하고 있는 콘텐츠 이용 기기를 모두 선택해주십시오.
(1) TV
(2) 컴퓨터(노트북 포함)
(3) 태블릿
(4) 스마트폰
(5) 오디오 기기(블루투스 스피커 포함)
(6) 게임기
(7) 기타(

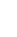


집필내역

연구책임

김소연 한국문화관광연구원 연구원: 연구총괄

연구진

주익현 광운대학교 산학협력단 연구교수: 제2장 제2절, 제3장 제1절 일부

연구 참여

이수현 연세대학교 사회학과 박사과정: 제2장 제1절, 제2절 일부

콘텐츠 이용자 데이터 개발 기반연구

발행인 김대관

발 행 처 한국문화관광연구원

서울시 강서구 금낭화로 154

전화 02-2669-9800 팩스 02-2669-9880

http://www.kcti.re.kr

인 쇄일 2021년 7월 9일

발행일 2021년 7월 9일

인 쇄 인 (사)한국장애인이워크협회 일자리사업장

I S B N 978-89-6035-862-193300

DOI https://doi.org/10.16937/kcti.rep.2021.e2 
OPEN

한국문화관광연구원

서울특별시 강서구 금낭화로 154

전화 02-2669-9800

팩스 02-2669-9880

www.kcti.re.kr 